Florida International University

FIU Digital Commons

\title{
Masculinidad y Nación: Modelos alternativos de masculinidad en las obras de Juan Goytisolo y Mario Vargas Llosa
}

Jose M. Morcillo Gomez

Florida International University, jmorc001@fiu.edu

Follow this and additional works at: https://digitalcommons.fiu.edu/etd

Part of the Latin American Literature Commons, Modern Literature Commons, and the Spanish Literature Commons

\section{Recommended Citation}

Morcillo Gomez, Jose M., "Masculinidad y Nación: Modelos alternativos de masculinidad en las obras de Juan Goytisolo y Mario Vargas Llosa" (2019). FIU Electronic Theses and Dissertations. 4037.

https://digitalcommons.fiu.edu/etd/4037

This work is brought to you for free and open access by the University Graduate School at FIU Digital Commons. It has been accepted for inclusion in FIU Electronic Theses and Dissertations by an authorized administrator of FIU Digital Commons. For more information, please contact dcc@fiu.edu. 


\title{
FLORIDA INTERNATIONAL UNIVERSITY
}

Miami, Florida

\section{MASCULINIDAD Y NACIÓN: MODELOS ALTERNATIVOS DE MASCULINIDAD EN LA OBRA DE JUAN GOYTISOLO Y MARIO VARGAS LLOSA}

\author{
A dissertation submitted in partial fulfillment \\ of the requirements for the degree of \\ DOCTOR OF PHILOSOPHY \\ in \\ SPANISH \\ by \\ José Manuel Morcillo-Gómez
}




\section{To: Dean John Stack}

Steven J Green School of International Relations and Public Affairs.

This dissertation, written by José Manuel Morcillo Gómez and entitled, Masculinidad y Nación: modelos alternativos de masculinidad en la obra de Juan Goytisolo y Mario Vargas Llosa, having been approved in respect to style and intellectual content, is referred to you for judgment.

We have read this dissertation and recommend that it be approved.

$\begin{array}{r}\text { Santiago Juan Navarro } \\ \hline \text { Nicola Gavioli } \\ \hline \text { Ana María Bidegain } \\ \hline \text { María Asunción Gómez, Major Professor }\end{array}$

Date of defense March 29, 2019

The dissertation of José Manuel Morcillo Gómez is approved.

Dean John Stack

Green School of International Relations and Public Affairs

Andrés G. Gil

Vice President for Research and Economic Development and Dean of the University Graduate School

Florida International University 2019 
(C) Copyright 2019 by José Manuel Morcillo Gómez

All rights reserved. 


\section{DEDICATORIA}

A mis padres, Aurora y Manuel y a mis dos hijos: Pablo y Javier. 


\section{AGRADECIMIENTOS}

Quiero agradecer muy sinceramente la disposición, ayuda y confianza demostrada por muchas personas que desde el inicio de esta nueva etapa personal me han apoyado desde ambas orillas del Atlántico. Aurora Morcillo y Charles Blaiker han sido quienes hicieron posible mi llegada a Estados Unidos y me ofrecieron la tranquilidad necesaria para poder afrontar los retos que vendrían en esos cuatro años de vida en Miami. Dejar el país que ha sido el hogar durante 46 años de tu vida no es fácil; aún recuerdo las palabras de mis padres, que, aun siendo mayores, entendían con generosidad, que la marcha era necesaria si se querían abrir nuevas oportunidades con más futuro. Tampoco olvido cuando Emilia Morcillo me dijo: "creo que debes intentarlo, yo apoyo esa idea también" y le agradezco que me lo hiciera saber de forma tan clara porque son palabras llenas de mucho amor y mucha generosidad.

En FIU, Luis Sánchez, director del English Language Institute me ofreció, sin ni siquiera conocerme personalmente, la llave para poder obtener mi Visa F1 en Estados Unidos como estudiante y gracias a ello, pude finalmente conseguir mi admisión definitiva en el programa de doctorado de español. En el departamento de Lenguas Modernas siempre encontré el apoyo de su directora, la doctora Pascale Becel que sigue siendo ahora una persona que cuida de mí como parte del equipo docente del departamento que dirige. Otra mención especial merece la doctora María Asunción Gómez, que en su papel de adviser, ha sido en todo momento una consejera y alguien que ha hecho que trabaje hasta el límite de mis capacidades para intentar sacar lo mejor de mí. La doctora Melissa Baralt me ha dado todo lo que un profesional de la educación puede necesitar. Sus clases de metodología y de lingüística me han abierto un nuevo 
mundo al que dedicar mi tarea pedagógica. He aprendido de ella que la humildad profesional es una de las mejores cualidades porque te enseña que siempre se puede aprender algo nuevo. Ella me permitió también, tener el honor de publicar conjuntamente por primera vez en una revista norteamericana.

Agradezco también lo que he aprendido de todo el profesorado que me dio clases durante mi doctorado. Me han puesto en las manos un mundo que desconocía y que ha enriquecido mi conocimiento y admiración por la cultura hispana. No puedo olvidar tampoco a la doctora Gema Muñoz de UM, porque con ella descubrí una perspectiva alternativa de un mundo complejo de por sí. Ella me abrió las puertas al conocimiento de la teoría queer que tanta luz me ha ofrecido en el análisis que hago en esta tesis. Por supuesto, sin el apoyo de UGS que aprobó mi TAship, nada de esto hubiera sido posible porque mis recursos económicos eran inexistentes.

Gracias a mi comité de tesis formado por cuatro personas que dijeron sí desde el mismo instante en que les dije que sería un honor que formaran parte de él. Están la doctora María Asunción Gómez como directora, el doctor Santiago Juan Navarro, el doctor Nicola Gavioli y la doctora Ana María Bidegain del departamento de Religious Studies.

De mis cientos de horas en la Green Library de FIU, no puedo olvidar a todo el personal que en ella trabaja y que siempre han estado disponibles para cuanto he necesitado. Mi especial cariño por Virginia, una persona que derrama alegría y que siempre te recibe con una sonrisa. Además, en la planta séptima del edificio apareció una mañana el futuro doctor Sinchul Back, alguien que es mi inspiración por su tenacidad en 
el trabajo . Él también es una maravillosa persona que iluminó mi vida desde ese día en que nos encontramos.

No olvido a mis estudiantes de FIU, entre los cuales se encuentra la doctora Jordana Pomeroy, directora del Museo Frost. Tuve la oportunidad de seguir en contacto con ella tras finalizar el curso que tomó conmigo y para mí es un ejemplo de capacidad de constante mejora.

Pablo y Javier son mis dos hijos y tengo que agradecerles su apoyo y comprensión. Ellos representan para mí la energía que me mueve en la vida porque las conquistas que consiga para mí, también serán para ellos. Sin ellos no entendería la razón de vivir.

Agradezco a la vida que me haya demostrado que con el afecto que uno recibe por parte de quienes te quieren bien y trabajando duro, uno puede llegar a conseguir reinventarse, no importa la edad. Escribo estos agradecimientos desde Qingdao, donde vivo y trabajo como Instructor de español desde hace ya dos años. No podría haber llegado hasta aquí si no hubiera sido por todas las personas que he mencionado aquí. ¡GRACIAS! 


\begin{abstract}
OF THE DISSERTATION
MASCULINIDAD Y NACIÓN: MODELOS ALTERNATIVOS DE

MASCULINIDAD EN LA OBRA DE JUAN GOYTISOLO Y MARIO VARGAS LLOSA

by
\end{abstract}

José Manuel Morcillo Gómez

Florida International University, 2019

Miami, Florida

Professor María Asunción Gómez, Major Professor

This dissertation focuses on the construction of national discourse from a gender perspective and examines how the concepts of nation and masculinity intersect each other in the works of Spanish writer Juan Goytisolo (1931-2017) and Peruvian Nobel laureate Mario Vargas Llosa (1936). This study sheds light on how fiction and real life events are interconnected in some of the novels and autobiographical works of both authors. The works analysed include: Señas de identidad (1966), Reivindicación del conde don Julián (1970), Juan sin tierra (1975), Coto vedado (1985), and Carajicomedia (2000) by

Goytisolo, as well as La ciudad y los perros (1963), La tía Julia y el escribidor (1977), El pez en el agua (1993), and El sueño del celta (2010) by Vargas Llosa.

Gender and queer theory inform the analysis of a hegemonic heterosexual model of masculinity prevalent in the societies the authors narrate. State-run institutions namely schools, family, religion, and the military - sanction, propagate, and ensure a model of masculinity with a faithful adherence to a patriarchal script. This uncompromising and rigid discourse predictively leads to fissures of rebellion, as the state approved model of heteronormative masculinity slowly cracks from the inside out. In this investigation, we explore how some individuals are able to rise up from the fringes 
and eventually break free. In breaking free, they also undermine the structural integrity of the crumbling state control system. Sometimes this rebel attitude is punished and, most of the time, it is even dismissed by power. In this study, we also explore alternative models of masculinity, which at times suffer the consequences of not fitting with the hegemonic type of manhood that heteronormative society accepts. 


\section{ÍNDICE}

CHAPTER

PAGE

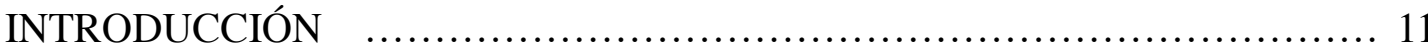

CAPITULO I:

Convergencias literarias e ideológicas en la obra

de Juan Goytisolo y Mario Vargas Llosa

CAPÍTULO II:

La vida se encuentra con la ficción: La hibridez en

la narrativa de Goytisolo y Vargas Llosa

\section{CAPÍTULO III:}

La masculinidad y la nación en la obra de Vargas

Llosa y Juan Goytisolo. (Comunidades imaginarias para la conformación

y también la crítica del estado-nación)

CAPÍTULO IV:

Modelos alternativos de masculinidad en la obra de

Mario Vargas Llosa y Juan Goytisolo

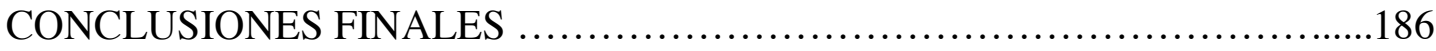

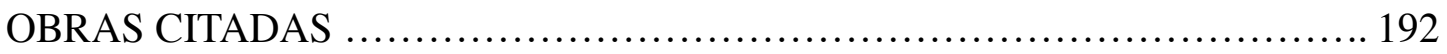

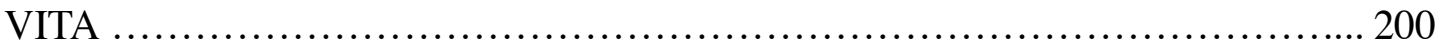




\section{INTRODUCCIÓN}

Esta tesis analiza cómo se representa la nación y la masculinidad en la obra narrativa, autobiográfica y ensayística de Juan Goytisolo y Mario Vargas Llosa. Goytisolo y Vargas Llosa comparten la experiencia del exilio y tienen una relación conflictiva con sus países de origen. Goytisolo decidió irse a vivir a Francia y más adelante trasladó definitivamente su residencia a Marruecos. A su vez, Vargas Llosa vive desde hace años en Madrid. Obtuvo la nacionalidad española en una decisión tomada con urgencia por el gobierno socialista de Felipe González tras recibir amenazas de expatriación por parte del entonces presidente de Perú, Fujimori, en venganza por las críticas que el escritor hizo al régimen que gobernaba en ese momento su país. Los dos autores comparten un sentido profundo por el significado de la libertad para los seres humanos y esto les llevará, en ocasiones, a ejercer un ataque directo contra los regímenes totalitarios que se vivieron en sus respectivos países y en otros puntos de Latinoamérica y Europa. Goytisolo mantuvo durante toda su vida una oposición frontal al régimen de Franco y esto se ve reflejado en su obra. Esta actitud le costó tener que abandonar España ante la presión política que sufrió, además de la censura a la que fueron sometidas algunas de sus obras. Vargas Llosa también hizo una dura crítica a los gobiernos totalitarios que se dieron en Perú, contra los que manifestó públicamente su oposición a través de sus textos ensayísticos y también en parte de su narrativa; de igual forma lo hace contra otros gobiernos totalitarios de otros países latinoamericanos. De esa crítica no se librarán tampoco gobiernos democráticos que, según su criterio, toman decisiones que ponen en peligro la libertad en su sentido más amplio. Fue crítico con el expresidente peruano Alan García y la decisión de nacionalización de la banca que tomó su gobierno. 
De hecho, este fue el asunto que provocó que Vargas Llosa participara de forma activa en política, presentándose como candidato a las elecciones presidenciales de Perú.

La crítica ha planteado en repetidas ocasiones que no podemos hablar de nación sin incorporar la cuestión de género. Algo que tienen en común estos sistemas totalitarios es la defensa férrea del sistema patriarcal, algo que también ocurre en las sociedades democráticas, aunque en estas últimas haya mayores opciones de disensión y expresión libre de alternativas. Para su supervivencia en el tiempo, el patriarcado se sustenta en modelos de género (masculinidad y feminidad) que garanticen el mantenimiento del poder masculino como eje de la organización social. En la obra de ambos autores encontramos una gran variedad de estos modelos de masculinidad que representan esa esencia de dominio masculino. Dichos modelos toman forma a través de los distintos personajes que aparecen en sus obras. Muchos de ellos son el fiel reflejo del modelo hegemónico masculino que tiene como señas de identidad la violencia, el poder y la heterosexualidad; esta última se considera indispensable para garantizar la reproducción y por tanto, la posibilidad de pervivencia del sistema. En este patriarcado, se considera que los hombres son quienes han de controlar la función de la reproducción, que es de las mujeres biológicamente, pero manejada desde el poder masculino a través de la promulgación de normativas y control para que se cumplan sus deseos sin importar el punto de vista de ellas. De esta forma ellos controlarán el linaje y, por tanto, la continuación en el tiempo del sistema patriarcal. Ese dominio llegará a tener como objetivo el control del cuerpo de la mujer, que son las únicas que en la especie humana tienen la capacidad biológica de tener descendencia. Ellas son consideradas también como indispensables en la cuestión de la reproducción no sólo biológica, sino en 
ocasiones, también de la ideología, eso sí, con un papel de sumisión a las decisiones que ejercen como derecho, los hombres. En el siglo XIX, la mujer era considerada el ángel del hogar y tenía el cometido de educar a sus descendientes para preservar los principios en los que se asienta la sociedad patriarcal. Durante la dictadura de Franco, y en otros regímenes totalitarios, la mujer es la virgen madre, alguien incapacitada para el placer sexual, pero encomendada socialmente a dar a luz a los hijos de la patria. Su cuerpo será controlado y legislado por parte del poder del patriarcado. Se le relega a un papel pasivo en el que se siguen los dictados del poder hegemónico masculino. Es un debate que vuelve a renacer con fuerza a estas alturas del siglo XXI con el surgimiento de movimientos ultraconservadores que entienden que la igualdad entre géneros es una amenaza para que el patriarcado permanezca.

Frente a este modelo de masculinidad controladora y hegemónica encontramos a los que se pueden considerar los Otros; quienes representan modelos alternativos de masculinidad y que también sufrirán en sus vidas, el efecto de ese sistema patriarcal que entiende como posible, solo una forma de ejercer la masculinidad. Algunos de estos hombres tienen voz y protagonismo en la obra de ambos autores y a ellos dedicaremos parte del trabajo que desarrolla esta tesis. Observando la interacción que hay entre ambos tipos de masculinidades podremos conocer los mecanismos de los que dispone la sociedad para garantizar la pervivencia del sistema patriarcal. Es aquí donde podremos comprobar la forma de actuar que tiene la sociedad disciplinaria de la que nos habla Foucault en su obra. Cuando leemos en la obra de Goytisolo y Vargas Llosa las historias de personajes masculinos como Roger Casement, Ricardo Arana, el esclavo; o Alberto, el poeta. Podremos comprobar que no cumplen con la norma hegemónica y lo que les 
ocurre; podremos comprobar cómo los que son considerados disidentes o transgresores del modelo, sufrirán en sus vidas el control social ejercido desde su entorno más cercano, Se les intentará reeducar, o dependiendo del momento histórico del que estemos hablando, curarles. En las situaciones más extremas serán enjuiciados, encarcelados e incluso ejecutados. Analizar las obras de ambos autores servirá para comprender las dos caras de la moneda: la forma en que actúan quienes controlan y la forma en que viven y padecen ese control los disidentes.

Entre ese grupo de los disidentes tendremos a los homosexuales. La homosexualidad es uno de los comportamientos más castigados a lo largo de la historia y la presión social sobre quienes la viven es feroz. Desde el sistema patriarcal se identifica constantemente la homosexualidad masculina con la feminidad en un intento de ataque directo a esta forma distinta de ser hombre. Para las sociedades patriarcales, la feminidad conlleva la inferioridad de las mujeres y su incapacidad para la autosuficiencia. Como bien explica Laqueur en Making Sex, las mujeres han ocupado un papel subsidiario a lo largo de la historia de Occidente. No es anecdótico que el movimiento de lucha por los derechos civiles de los homosexuales haya ido desde sus inicios de la mano con la lucha feminista, ya que son las mujeres las que inician esa oposición contra el patriarcado. La homosexualidad es considerada como un factor de riesgo para la supervivencia del poder del modelo hegemónico masculino ya que en parejas del mismo sexo, la relación sexual no tiene como finalidad la procreación. En la obra de Goytisolo y Vargas Llosa se aborda este tema de forma constante, aunque el planteamiento en cada uno de ellos es completamente distinto. Goytisolo representa en sí mismo ese modelo alternativo de masculinidad y hace pública su homosexualidad, al mismo tiempo que critica una 
ideología basada en principios religiosos que no toleran a las personas no heterosexuales. A partir de esta crítica al modelo controlador y la exposición de lo que supuso para él el reconocimiento de su orientación sexual, construye una idea alternativa de masculinidad que además servirá para formar un modelo muy diferente de identidad sexual y de identidad nacional en comparación con aquel en el que él fue educado. Sin embargo, a Goytisolo se le ha criticado su concepción falocéntrica del deseo sexual y el hecho de que su modelo ideal de masculinidad se inspira de forma continua en el mundo árabe y en esa visión romántica sobre la permisividad de este tipo de relaciones entre los hombres árabes; cuestión que está más cerca de una fantasía occidental que de una realidad, tal como veremos en uno de los capítulos de esta tesis.

En el caso de los textos de Vargas Llosa, se lleva a cabo un retrato certero de los mecanismos represores que la sociedad más conservadora utiliza para ejercer presión sobre todos aquellos que son o parecen homosexuales. A través de muchas de las historias de los personajes de su obra podemos analizar el efecto que tiene sobre estos hombres la censura, el control y la violencia ejercida sobre ellos para señalarles públicamente como culpables por su orientación sexual. Este rechazo es liderado por los propios hombres, son ellos los que se sienten con el derecho de juzgar y actúan violentamente contra los que son considerados como los otros. El escritor peruano ofrece en sus obras un espacio para estos hombres marginados, nos muestra la forma en que sufren, cómo reaccionan ante los ataques recibidos y cómo intentan protegerse. Todo ello nos ayuda a conocer de forma directa la presión social a la que esta forma de comportamiento masculino se ve sometido. Muchos de sus trabajos literarios se basan en su vivencia personal o en la de personajes históricos que le sirven de referente para 
desarrollar el personaje de la obra de ficción. Con respecto a su vivencia personal, conocemos a partir de su obra autobiográfica sobre el abuso que él mismo padeció a consecuencia de una relación tormentosa con su padre, quien temía que su hijo Mario pudiera ser homosexual, ya que mostraba en todo momento un gusto por la lectura, la música y el arte. Poner en evidencia la crueldad de una sociedad conservadora como la peruana, le ha costado críticas despiadadas por parte de muchas instituciones de su país. Sin embargo, a lo largo de toda su obra, Vargas Llosa ha seguido mostrando la vulnerabilidad y las injusticias que sufrieron los hombres que se alejaban del modelo hegemónico de masculinidad.

Al igual que en el caso de Goytisolo, en la obra del escritor peruano, encontraremos un discurso que nos muestra un modelo de nación que no entiende el ataque a la diversidad y a la existencia de libertad de pensamiento y acción por parte de los seres humanos. Ninguno de los autores objeto de esta tesis creen en el uso de la violencia ni tampoco apoyan una sociedad que no acepte como condición la existencia de la diversidad. La obra de ambos nos servirá para conocer el papel que tiene la masculinidad en la conformación de la idea de nación y cómo esta última necesita de la primera para poder expresarse en términos que van más allá del símbolo. La nación necesita de iconos, de modelos a seguir para poder llegar a ser algo más que una construcción abstracta.

Con respecto al trasfondo crítico sobre el que se basa el análisis de los textos de los dos autores, hemos encontrado abundantes estudios sobre ambos que analizan sus trabajos individualmente ${ }^{1}$. En algunos casos se trata de monografías sobre cada uno de ellos; en otros, son recopilaciones de artículos sobre sus obras . En contadas ocasiones, 
(Persino) encontramos trabajos que hablan exclusivamente de los paralelismos que se pueden dar en la narrativa escrita de los dos escritores. Pero no existen estudios comparativos, de ahí que esta tesis haga dialogar la obra de ambos autores y se centre en los paralelismos que se pueden apreciar en sus narrativas.

El aporte teórico del posmodernismo ${ }^{2}$, el feminismo y la teoría queer es fundamental para poder llevar a cabo el análisis de los textos seleccionados. La obra ensayística de Jacques Derrida y su cuestionamiento de la existencia de una verdad absoluta es el punto de partida de este estudio, el cual se propone deconstruir los textos de Goytisolo y Vargas Llosa para aportar una nueva lectura. Como explica Derrida, el texto escrito deja de pertenecer al escritor desde el momento de su publicación. Cuando se escribe se hace pensando en alguien y la lectura de esas palabras tendrán significado incluso cuando ya no exista el autor de las mismas. Roland Champagne recoge esa idea de Derrida que establece que "[in] every case, an event of writing detaches itself from its 'author'” (11). Esto permite abordar el análisis de textos desde perspectivas que permiten una visión más abierta y diversa.

Su visión se inspira por la arquitectura, aunque más adelante derivó hacia otras formas de expresión artística. Él niega que haya un cambio radical del modernismo al postmodernismo, habla de la existencia de un período intermedio al que denomina el "later modernism" que sería la transición entre dos momentos que además coinciden con el cambio profundo que comienza a tener la sociedad occidental con la aparición de las tecnologías y los cambios en las formas de producción. De lo planteado por este teórico,

\footnotetext{
2 Charles Jencks, uno de los padres del postmodernismo habla de cómo la gestación de este movimiento comienza en los años 20 y también plantea la polémica alrededor de la definición del mismo:

Post-Modernism to be as a cultural movement and historical epoch. But, as the reader will discover, the word and concept have changed over fifty years and have only reached such a clarification in the last ten. See as progressive in some quarters, it is damned as reactionary and nostalgic in others; supported for its social and technological realism, it's also accused of escapism (8).
} 
creo que es importante su idea sobre la posibilidad que ofrece este movimiento en lo que respecta a la hibridez de las obras que se producen: "Finally, to many of its adherents and me, it suggests the possibilities of hybridation, of being partly Modern and partly something else, or a critical and selective continuation of Modernism and its transcendence" (65).

Es un momento para experimentar e innovar en la narrativa, de abordar nuevas técnicas y esto es muy importante a la hora de analizar los textos de los dos autores que estudio en esta tesis. En el caso de parte de la obra de Goytisolo y Vargas Llosa podemos encontrar una perspectiva que huye del sistema binario de representación de la realidad. No comparten el hecho de que tan sólo existan dos únicas posibilidades a la hora de elegir personajes o tramas en sus textos, ya que esto limita poder conocer matices y la diversidad de opciones existentes. Goytisolo y Vargas Llosa huyen de la idea de la primacía de ciertas culturas y su discurso puede considerarse como poscolonial, en el sentido que Hommi Bhabha da a este término: "The postcolonial perspective resists the attempt at holistic forms of social explanation. It forces a recognition of the more complex cultural and political boundaries that exist on the cusp of these often-opposed political spheres" (248). En obras como El sueño del celta de Vargas Llosa o La reivindicación del conde don Julián de Goytisolo podemos encontrar ejemplos de esta perspectiva poscolonial. La obra de Goytisolo desarrolla una crítica mordaz de esa sociedad española colonizadora y ultra católica. A su vez, Vargas Llosa critica abiertamente a los imperios colonizadores europeos (Bélgica y Gran Bretaña) a través de la voz del personaje protagonista, un diplomático británico que escribió dos informes sobre la violación de los derechos humanos contra los indígenas en el Congo y en Perú 
por parte de los poderes de aquel momento histórico en que el poder colonial europeo sometía sin miramientos sus territorios en el continente africano y americano.

Cuando Benedict Anderson nos habla de la "nación imaginada" se refiere al hecho de que muchas de las personas que supuestamente pertenecen a ella no se conocen entre sí pero se encuentran identificadas con una idea que genera una unión entre todas ellas. Se trata de una construcción que tiene un carácter abstracto y que necesita de una serie de símbolos, de modelos, de narrativas que puedan ayudar a construir los rasgos que la definen. En Goytisolo y Vargas Llosa hay una crítica a diversas instituciones, a personajes históricos o al uso que se hace de la lengua de cada una de sus naciones de origen. Nos muestran a través de su obra, características de esa comunidad imaginaria a la que pertenecen y proceden en ocasiones a ejercer una crítica hacia el modelo resultante.

Además de la teoría de Benedict Anderson, se explora el concepto de nación basándonos en los ensayos de George Mosse, Ida Bloom, Karen Hagemann, Catherine Hall, Nira Yuval y Hommi Bhabha, y se presta especial atención a sus reflexiones sobre la relación entre nación y género. Mosse explica cómo la sexualidad juega un papel fundamental en la formación del ideario del estado nacional-socialista de la época nazi en Alemania. Los textos de Bloom, Hagemann y Hall muestran varios ejemplos de cómo lo femenino o lo masculino contribuyen a la formación de los símbolos de las naciones en una interpretación organicista de la idea de nación. Es la traslación del funcionamiento del cuerpo humano al cuerpo del Estado.

El cuerpo se considera una pieza fundamental en la representación de la nación, tal y como explica de forma convincente Aurora Morcillo en varios de sus ensayos que 
tratan sobre la función del cuerpo femenino en la conformación de la idea franquista de la nación española. El régimen de Franco utiliza el cuerpo de la mujer para representar la función que se espera de ella como madre, como virgen y también para simbolizar mediante ese cuerpo parte de las acciones represivas que pondrá en marcha el dictador. De forma similar, en Nationalism and Sexuality, Mosse explica el uso de iconos masculinos en la antigua Grecia para representar la fuerza, que será identificada a su vez como símbolo de la fortaleza del movimiento nazi en Alemania.

La aparición de los cuerpos con un valor simbólico es recurrente en las obras de Goytisolo y Vargas Llosa. En esta tesis analizaremos, por tanto, el rol del cuerpo masculino y su función simbólica en el proceso de creación de una identidad nacional. Para ilustrarlo, en el capítulo tercero exploro el cuerpo militar que aparece descrito en $L a$ ciudad y los perros (1963) y en el capítulo cuarto analizo la interpretación tan particular que se hace sobre el uso de los cuerpos masculinos en Juan sin Tierra (1970) de Juan Goytisolo, a la hora de abordar la homosexualidad. A través de la interpretación de las funciones del cuerpo en las obras seleccionadas llegamos a la lectura de las distintas construcciones sociales que se hacen de la masculinidad y, en definitiva, de la nación.

Goytisolo y Vargas Llosa incorporan en su trabajo una serie de personajes que nos permitirán conocer modelos alternativos de masculinidad. Connell hace un profundo análisis sobre los distintos modelos de masculinidad y el rol que cada uno de ellos tiene en la sociedad. Además de su trabajo, tendremos el de otros teóricos que han hecho estudios sobre este tema (Aboin, Eric Anderson, Blazina, Arnold, Brittan, Boker, Braudy), abordando distintas perspectivas sobre cómo son representadas las distintas formas de masculinidad. Aunque se defiende el hecho de que la forma de masculinidades 
es diversa, ya se mencionó anteriormente que hay un modelo hegemónico que se basa en la violencia, en el manejo del poder y en la heterosexualidad como principales rasgos distintivos. Es aquí donde juegan un papel fundamental los estudios hechos por Michael Foucault. El filósofo francés habla sobre la existencia de una sociedad disciplinaria y explica el papel que juegan para el control de ese poder hegemónico la familia y las instituciones educativas, religiosas, militares. En las obras de Goytisolo y Vargas Llosa hay alusiones continuas a todas ellas y a su funcionamiento.

En esa sociedad disciplinaria, la homosexualidad será castigada a través de la maquinaria de poder que protege el modelo hegemónico de masculinidad. Es algo que se trata en la obra de Foucault, pero que, además, cuenta con otras perspectivas que vendrán de la mano de otros autores, tales como Deleuze y Guatari en su Anti-Edipo. En esta obra nos hablan de los seres humanos como máquinas deseantes y el interés que hay a nivel económico para conseguir que el deseo siga su curso siempre que no ponga en peligro al sistema económico capitalista. Establecen por tanto una relación directa entre deseo y economía, un tema explorado también por Guy Hocquenghem, autor que vincula directamente el sistema económico capitalista y las formas de deseo, centrándose expresamente en qué papel juega en ese sistema el deseo homosexual. Que estos autores aborden la relación entre deseo y economía nos abre más opciones a la hora de interpretar la obra de nuestros dos escritores ya que la economía es algo que también está relacionada con la nación y el patriarcado. A lo largo de los siglos, ha habido un interés expreso por parte del sistema capitalista por castigar la homosexualidad. Como recuerda Mard D. Jordan, la sodomía fue inventada por los teólogos medievales (2) para castigar a todas aquellas personas que tuvieran relaciones homosexuales. Bajo esa construcción 
semántica se llevaron a cabo detenciones, torturas y ejecuciones. Fue el delito más castigado por la Inquisión desde sus inicios hasta sus últimas actuaciones en el siglo XVIII. El origen del vocablo se sitúa en siglo XI y se menciona al teólogo Peter Damian como el responsable de su utilización como categoría que calificaba pecados y culpas. El concepto de sodomía sufre un proceso de abstracción a lo largo de la historia, hasta el punto de perder su contenido semántico real:

To abstract an essence from a proper name is to reduce the person named to a single quality. All that you need to know about the Sodomites is that they practiced Sodomy. In this way, abstraction from a proper name is deeply connected with the project of essentializing persons. A term like Sodomy suggests, by its very grammatical form, that it is possible to reduce persons to a single essence, which can then be found in other persons, remote from them in time or place. (42)

Más adelante, como señala Guy Hocqhenguem, la palabra homosexual tal y como la conocemos en la actualidad, fue inventada en 1869 por un psiquiatra alemán. Existe la intención de buscar un término que ayude a identificar lo que en ese momento pasa a ser considerado como una enfermedad y la psiquiatría será la encargada de su tratamiento. Como dice Hocqhenguem: "The advent of psychiatry and mental hospitals manifests society's ability to invent specific means for classifying the unclassifiable (see Foucault's Histoire de la Folie a l'age classique); this is how modern thought has created a new disease, homosexuality" (51). Hay sin duda todo un proceso histórico para castigar, curar o eliminar a los que públicamente se declaren homosexuales. Estas nociones serán claves para entender el cuarto capítulo sobre masculinidades alternativas en la obra de Goytisolo y Vargas Llosa.

A lo largo de los cuatro capítulos de esta tesis, busco respuesta a las siguientes preguntas: ¿Cómo se establece la relación entre nación y masculinidad a través de los 
textos de ambos autores? ¿Cómo la obra de Goytisolo y Vargas Llosa nos ayuda a conocer la estructura de poder que mantienen los gobiernos totalitarios que existieron en España o Perú? ¿Cómo se refleja a través de sus textos su experiencia personal y su compromiso ideológico y político? ¿Cómo se representa en la obra de ambos autores el modelo hegemónico de masculinidad a través de personajes que simbólicamente representan a la nación? ¿Cómo es el proceso de inclusión o exclusión social vivido por los personajes masculinos que representan un modelo alternativo de masculinidad en la obra de ambos? ¿Cómo podemos ver reflejada a través de la obra de ambos ese sistema de control social para la defensa del patriarcado independientemente de la existencia o no de un gobierno totalitario? 


\section{CAPÍTULO I}

Convergencias literarias e ideológicas en la obra de Juan Goytisolo y Mario Vargas Llosa

Mario Vargas Llosa nace en Perú y lleva viviendo muchos años fuera de su país de origen; Juan Goytisolo, es barcelonés de nacimiento y ha vivido exiliado fuera de España durante muchos años también; es más, tras su muerte, no consintió ser enterrado en su país de origen y sus restos reposan en el cementerio de Larache. Como señala Wilfredo Corral, en ambos autores se da una situación de relación con sus países de origen que les hace sentirse como separados de ellos: "Un par de hechos concomitantes son la condición de autoexiliados (sobre todo en el caso de Goytisolo y Vargas Llosa) y cierta actitud hacia la literatura y sus países" (839). A lo largo de este capítulo haremos un repaso sobre qué puntos en común tienen ambos autores, así como sobre sus estilos narrativos, sus posicionamientos políticos e ideológicos y su visión acerca de la literatura.

Hay sendos artículos que estos dos autores se dedican mutuamente el uno al otro a través de los cuales se establece una comunicación entre ambos y nos permiten conocer cuál es la opinión que tiene cada uno de ellos sobre el otro. En ambos textos tenemos lo que escribieron el uno sobre el otro directamente, sin el filtro de ningún crítico literario. La mención a los artículos sigue un orden cronológico de publicación. Será en el año 1971 cuando Mario Vargas Llosa publica "Reivindicación del conde don Julián o el crimen pasional", que será incluido en su libro de ensayos Contra viento y marea. Llama la atención el inicio de su texto cuando califica a Goytisolo de forma irónica como alguien que no es "patriota": "Hay que desconfiar de los novelistas que hablan bien de su 
país: el patriotismo, virtud fecunda para militares y funcionarios, suele ser pobre literariamente" (174). Estas palabras cobran especial sentido al haber sido escritas justo un año después de la publicación de Don Julián. ${ }^{3}$ Recogen la admiración personal que siente Vargas Llosa por el escritor catalán al haber demostrado una gran valentía al hacer una crítica tan abierta de España, o mejor dicho, de la España más oscura, la que representaba en ese momento a la dictadura franquista. Goytisolo defiende que los valores principales de España son su historia multicultural y el beneficio que representa la coexistencia de varias tradiciones religiosas y culturales en un mismo territorio. Con respecto a esta cuestión de ataque a su tierra natal, dice al respecto: "el hispanicidio sistemático ocupa toda la vida de este narrador sin silueta y sin historia, voz pertinaz que desacredita y afrenta. Su furor es solo negativo (no quiere corregir, mejorar, sino demoler) y universal" (175). En el lenguaje utilizado en el ensayo encontramos esa complicidad y apoyo al texto del escritor de Barcelona. Este acercamiento y complicidad se da porque el Nobel también ha escrito obras donde critica abiertamente a su Perú de nacimiento.

No es sólo Vargas Llosa el que se enfoca en este homicidio de la patria, sino que críticos como Roy C Boland e Inger Enkvist hablan del ataque al país de origen como una característica de los autores del Boom: "Certainly after being exposed to Vargas Llosa's “perunicidio", Fuente's "mexicanicidio" and Goytisolo's "hispanicidio" it's impossible for a reader ever again to view Peru, Mexico or Spain in the same light" (8). Goytisolo procede al hispanicidio mencionado en su novela Reivindicación, obra de referencia en el desarrollo de esta tesis. En ese proceso de destrucción, atacará los mitos y símbolos que

\footnotetext{
${ }^{3}$ Reivindicación del conde don Julián forma parte de la llamada trilogía Mendiola. Es la segunda de tres novelas y en ella hay una crítica mordaz de esa idea de la España unida, del caballero cristiano y del honor y la pureza de sangre como valores principales del país a lo largo de la historia española.
} 
han sido utilizados en períodos determinados de la historia de España para construir una idea de país con la que el autor barcelonés no se siente en absoluto de acuerdo, ante todo porque será el dictador Francisco Franco el que haga uso de dichos mitos para borrar un pasado diverso y en el que la convivencia o la multiculturalidad formaban la esencia que hace diferente a la península con respecto a otros países de Europa. Este ataque se basa en la continua provocación y el sarcasmo. Don Julián será una novela donde se explica el daño irreparable que se hace a un país cuando se prescinde para su definición de visiones que incorporen la diversidad como elemento esencial de su historia y de una cultura llena de matices diferenciadores. ${ }^{4}$ Sobre este proceso de crítica que hace Goytisolo en su novela, con la que pretende aniquilar la idea de la España franquista, Vargas Llosa menciona en el artículo los instrumentos que usa el escritor español para llevar a cabo ese proceso de destrucción: por un lado, nos habla de cómo lo que realmente sirve para sublevarse es la forma en que se utiliza el lenguaje. Según el premio Nobel, la forma de escribir es lo más extremadamente provocador que tiene esta obra: "su blanco central es la lengua donde todas las falsedades, horrores y tonterías que lo abruman han dejado una marca" (175). No podemos olvidar que la lengua es uno de los signos de identidad fundamentales a la hora de dar lugar a la idea de nación y forma parte de su núcleo. ${ }^{5}$ Por eso su obra "consiste en un sabotaje, en la artera desintegración de esa lengua atrofiada por la sumisión al pasado" (Contra viento 176). Goytisolo hace de la lengua un arma

\footnotetext{
${ }^{4}$ Goytisolo pone atención en los rasgos que distinguían a la España mestiza, la España de la diversidad religiosa existente antes de la toma por los Reyes Católicos del último reino nazarí de Granada en 1492 y la posterior firma del decreto de expulsión de los judíos y de los musulmanes que no quisieran convertirse al cristianismo. Al-Andalus y su diversidad religiosa y cultural son una fuente constante de inspiración para Goytisolo. No olvidemos que durante los últimos años de su vida, Goytisolo residió en Marruecos y que tras su exilio en Francia, estuvo en Tánger, lugar de residencia para muchos escritores y artistas de origen europeo y norteamericano, como señala Joseph Boone en su artículo Vacation Cruise; or the Homoerotics of Orientalism.

${ }^{5}$ Hay varios capítulos dedicados a esta cuestión en Imagined Communities de Benedict Anderson.
} 
fundamental a lo largo de toda su narrativa. Hay ocasiones en las que inventa vocablos o utiliza varios idiomas o dialectos del español para crear ese ambiente crítico y destructor, que a la vez utiliza para provocar a quienes defienden la necesidad de tener tan sólo una lengua común que garantice el purismo del español. Como segundo instrumento para llevar a cabo ese hispanicidio al que asistimos en la novela de Don Julián, Vargas Llosa añade que hay otra forma de ataque que, según su punto de vista, utiliza el autor español:

La otra táctica es insidiosa, ligeramente masoquista. Consiste en un collage que viene sin aviso, disuelto en su contexto, que el lector sólo puede olfatear, adivinar, al verse enfrentado, de pronto, con frases de una asombrosa chatura o de una engolada ruidosa nimiedad. Así, paradójicamente, el libro se alimenta en buena parte de lo que denuncia, está construido con los materiales que aborrece. (176)

La España que ofrece Goytisolo como alternativa no puede ser explicada sin la España que él critica tan abiertamente. Vargas LLosa habla sobre la necesidad que tiene el autor español de la existencia de un modelo, de un mito ya existente, para poder proceder a su destrucción y así dar lugar a la generación de otro alternativo que sirva de contrapunto al que él rechaza. Según Vargas Llosa, Don Julián es una novela que representará "un crimen pasional, algo así como el disparo enfurecido del amante celoso contra la mujer que lo engaña" (Contra viento 178). Sin entrar en el matiz del símil, de lo que habla Vargas Llosa es de la existencia de un punto de inflexión que marca un antes y un después en la carrera literaria de Goytisolo. ${ }^{6}$ Se produce asimismo una catarsis personal, un proceso que va del plano personal al ámbito de lo público y de ahí, de nuevo a lo personal, como si no se pudiera desconectar el entorno y el contexto social del personal y viceversa.

\footnotetext{
${ }^{6}$ Es relevante el hecho de que la novela se publique en 1975, coincidiendo con la muerte del dictador español y el comienzo de la Transición política a la democracia. Es un nuevo momento político y social que invita a imaginar nuevos escenarios. Juan sin tierra tiene también ese valor de proyecto de futuro. Hay hechos que se refieren al pasado pero también aparece mucho de lo que será el proyecto de vida y el proyecto literario que se pretende desarrollar.
} 
En las palabras del ensayo de Vargas Llosa hay evidencia de su admiración por el trabajo y la talla intelectual de Juan Goytisolo. Veintitrés años después, Goytisolo publica en El País un ensayo con un título significativo: "Elogio en el desacuerdo”. En dicho texto, Goytisolo no procede al halago sin más de su colega, sino que hace de la diferencia entre ambos un elemento para exaltar las grandes cualidades que como intelectual, ensayista y escritor tiene Vargas Llosa. Goytisolo critica aquí el hecho de que se intentara vetar a Vargas Llosa para formar parte del jurado de la Mostra de Venecia en $2006 .^{7}$ Aprovecha además este incidente para hacer una crítica directa de la izquierda europea y su actitud sectaria, añadiendo que hechos como este "ilustran de manera patética la persistencia en el campo de la izquierda de unos hábitos de sectarismo, dogmatismo e intolerancia directamente responsables de su actual derrumbe y desbandada" (173). Si en algo coinciden ambos autores es en su crítica a ese sectarismo político del que escribe Goytisolo en el artículo y que vivió la izquierda a partir de las derivas que tomaron gobiernos del bloque comunista con acontecimientos como la invasión de Checoslovaquia por parte de la Unión Soviética, hecho contra el que ambos escritores mostraron públicamente su repulsa. De igual forma tendremos otro punto de coincidencia cuando ambos hacen una denuncia abierta a ciertas actuaciones del régimen de Fidel Castro. ${ }^{8}$ En el texto de este artículo sobre Vargas Llosa, Goytisolo expresa claramente la admiración hacia su colega profesional y resalta:

\footnotetext{
${ }^{7}$ Karmentxu Marín comenta en un artículo escrito en el suplemento de Cultura de El País a raíz de este incidente: ""Simpático: me parece que hayamos vuelto a la excomunión, al estalinismo, a la inquisición". Así ha respondido Mario Vargas Llosa al veto para que formarse parte del jurado de la Mostra de Venecia por parte de uno de los consejeros de la Bienal, el filósofo Umberto Curi, quien le considera carente del suficiente pedigrí democrático. El autor de La ciudad y los perros afirma haber llamado a la dirección de la Mostra por si querían prescindir de él, a lo que se ha negado el director, Gillo Pontecorvo".

${ }^{8}$ El caso Padilla fue el detonante para que muchos intelectuales que habían apoyado abiertamente la Revolución cubana, empezaran a tener dudas sobre lo que estaba ocurriendo en la isla caribeña. Hubo un
} 
La honestidad y la valentía con las que defiende sus ideas, a menudo impopulares, a cuerpo descubierto. No son por desdicha frecuentes en nuestros predios de estrategas zorrunos y ladinos tácticos, maestros en el cultivo de la restricción mental y la maniobra secreta, que más intelectuales, parecen ajedrecistas por su arte de mover prudentemente las fichas en el tablero de su grandiosa o mediocre carrera profesional. (173)

Ambos son intelectuales que no ocultan sus planteamientos políticos y la visión que tienen de la realidad. Es más, Goytisolo deja muy claro que Vargas Llosa es "un ensayista político de una enjundia y coherencia insólitas y admirables" (173), además de lo que dice sobre sus novelas que se "cuentan entre las mejores de las últimas décadas" (173). La excusa que se pone para no dejar al escritor peruano formar parte de este jurado, es que era fascista, cuestión que zanja Goytisolo en este artículo al recomendar la lectura de Desafíos a la libertad, un libro de ensayos en el que "el novelista denuncia en términos elocuentes los estragos del racismo, nazismo, xenofobia y de las llamadas dictaduras de derechas" (174). Queda por tanto claro, que no puede ser acusado de fascista alguien que repetidamente hace de la defensa de libertad y la democracia uno de sus principales principios de actuación.

A pesar de este apoyo explícito, Goytisolo también reconocerá algunas diferencias con respecto a Vargas Llosa y es que, según él, la deriva que toma la crítica hacia el comunismo es la de llegar a defender los principios del libre mercado como únicos que garanticen la libertad de los individuos. Él se refiere a esa frustración que sienten muchos intelectuales que apoyaron en su momento a la Unión Soviética y que tras ver la deriva de este proyecto político dejaron de hacerlo y entraron en una actitud de conformismo, aceptando que no había otra alternativa a la ley de libertad de mercado y el papel de éste como regulador social. La intervención del estado en la economía es 
considerada perjudicial. En este punto concreto, Goytisolo mostrará un espíritu más contestatario a esta idea de no intervencionismo estatal. A pesar de este distanciamiento entre ambos en lo que respecta a este punto, los dos escritores vuelven a coincidir en algo que afecta al sistema democrático y que tiene que ver con el mercado: "Su principal enemigo, advierte con razón, lo encarna el mercantilismo, esto es, las alianzas mafiosas del poder político y empresarios influyentes para, prostituyendo el mercado, repartirse dádivas, monopolios y prebendas" (175). Se trata de una crítica frontal a la corrupción y al interés económico personal como única guía en la toma de decisiones que afectan a la ciudadanía. Ambos rechazan estas prácticas que son una verdadera amenaza para cualquier sistema democrático.

Será al final del artículo de Goytisolo donde encontremos un desacuerdo manifiesto con Vargas Llosa. Eso sí, la forma en que es expresado demuestra ese profundo respeto intelectual hacia alguien que utiliza las mismas herramientas para argumentar la convicción profunda en la justicia y la necesidad de garantizar la libertad individual:

La confianza de Vargas Llosa en los valores y principios cívicos del ultra liberalismo para corregir unos comportamientos y mentalidades que no han cambiado desde los tiempos de Plauto y La Celestina, ¿no es excesiva y voluntarista? Si una visión del futuro de la cultura peca a mi entender de pesimismo, su fe en una ética del libre mercado incurre, creo yo, en el defecto opuesto. ¡Ojalá me equivocara yo en lo último y él en lo primero!. (176)

Con ese último guiño queda rubricada la mutua admiración intelectual que ambos se profesan y por supuesto. También se nos dan muchas pistas de que su trabajo como ensayistas, pensadores y escritores ha tenido muchos puntos en común. Otra cosa es cómo ha evolucionado cada uno de ellos con el paso del tiempo. 
Ambos autores forman parte de la conocida generación del Boom, un movimiento

literario clave que tiene conexiones no solo con Latinoamérica, sino también con España: ${ }^{9}$

In the case of the novel, writers form both the Iberian Peninsula and Latin America had been heading more and more in the same direction, experimenting increasingly with similar themes, styles and techniques since the heady days of the "boom" in the 1960s right up to the current vogues for postmodernist, detective and "new" historical fiction. (Boland y Enkvist 7)

El Boom surge en un momento en que hay cambios profundos a nivel social y con el surgimiento de revoluciones políticas y sociales de gran calado, como es el caso de las revueltas del 68 en Francia, las dictaduras de distinto signo en el continente latinoamericano, la dictadura fascista con Franco en España, el desarrollo de las teorías marxistas y el surgimiento de partidos de izquierda que se inspiran en el marxismo pero que se distancian del régimen soviético para dar lugar a lo que Santiago Carrillo identificaba como eurocomunismo. ${ }^{10}$ Se trata de un nuevo período de revolución en el mundo de la filosofía con pensadores como Camus, Sartre o Simone de Beauvoir, un momento en el que los movimientos feministas y los de defensa de los derechos sociales y por igualdad, cobran mucha relevancia. En el ámbito de las expresiones artísticas se dan

\footnotetext{
${ }^{9}$ No olvidemos que hubo un momento en que tan sólo se mencionaban a escritores latinoamericanos dentro de este grupo de escritores. Existen puentes entre ambos lados del océano que nos demuestran que esta generación no estaba presente tan sólo en el continente americano: "Gabriel García Márquez has declared that he feels uneasy at the continued separation of the literatures of Spain and Latin America" (Roy C Boland e Inger Enkvist 7). Es un momento que marca históricamente una nueva relación entre escritores de habla hispana de ambos continentes. Todos sabemos que a raíz de la proclamación de las repúblicas independientes americanas durante el siglo XIX hasta principios de los años 20 hay una situación que invita a apartarse de la metrópoli para así conseguir y desarrollar señas de identidad propias. Hay un rechazo de todo lo que venga de España y un intento de buscar inspiración en otros países del continente europeo. La literatura francesa es básica para entender el modernismo en Latinoamérica.

${ }^{10}$ The parties included in the "Eurocomunist" trend are agreed on the need to advance to socialism with democracy, a multiparty system, parliaments and representative intitutions, sovereignity of the people regularly exercised through universal suffrage, trade unions independent of the State and of the freedom, freedom for the opposition, human rights, religious freedom, freedom for cultural, scientific and artistic creation and the development of the broadest forms of popular participation at all levels and in all branches of social activity"(Carrillo 110).
} 
también importantes novedades que afectan a la pintura, a la arquitectura y por supuesto, también a la literatura. Es en esta última donde esta generación del Boom marca un antes y un después para la novela latinoamericana. Se puede decir que es el momento en que las obras de autores latinoamericanos adquieren una insólita proyección internacional.

Mayder Dravasa hace alusión a este contexto histórico, político y cultural en los siguientes términos: "It's clear that, for certain critics, if the Boom existed, it was due to a series of political, cultural, and economic factors which allowed certain SpanishAmerican writers to be recognized as a homogeneous group despite the differences in their ages and their background" (X). Sin ese contexto no se habrían dado situaciones que en muchos momentos hicieron que Goytisolo y Vargas Llosa participaran conjuntamente en eventos y publicaran escritos que mostraban su opinión y puntos de vista personales ante lo que acontecía políticamente en diversos puntos de América Latina y también en Europa. Barcelona es la ciudad clave para todo ello, el lugar donde se encontraba la sede de Seix Barral, la editorial que decide publicar las principales obras de este movimiento literario. Dravasa incide en la importancia de esta ciudad del Mediterráneo cuando señala que:

Barcelona was also connected with the foundation of the journal Libre in 1971. With its offices actually in Paris's Rue e Bievre and with collaborators such as the Spanish writer Juan Goytisolo, Gabriel García Márquez, Mario Vargas Llosa, the Argentine writer Julio Cortázar, Carlos Fuentes, the Chilean writer Jose Donoso, the Cuban writer Severo Sarduy, and the critic Carlos Franqui. (2)

Esa generación no sólo se dedicaba a escribir novelas, sino que era muy activa políticamente; es más, la política fue uno de los puntos de unión de muchos de los escritores que formaban parte de este movimiento literario. De hecho, Dravasa nos habla también de un hecho que ocurrió durante una reunión que tuvo lugar en el piso que en 
aquel momento tenía Mario Vargas Llosa en Barcelona. Allí fue donde se reunieron él, Juan Goytisolo y Carlos Barral, el dueño de la editorial Seix Barral, junto a otros críticos y escritores para redactar el segundo borrador de la carta que se dirigiría a Fidel Castro en protesta por la detención del escritor Heberto Padilla. ${ }^{11}$ Este hecho confirma que fueron varios los puntos en común y de colaboración entre ambos escritores, sobre todo en lo que a causas políticas se refería. La cuestión de la revolución cubana fue algo que unió a muchos de ellos y también fue algo que causó una decepción colectiva entre muchos de estos intelectuales cuando empezó a tomar una deriva más parecida a una dictadura militar que a una revolución popular. Esta cuestión de camaradería ideológica es importante, pero no sería la única razón por la que Goytisolo ha sido considerado miembro del Boom. Carlos Fuentes da razones de mayor peso, tal como nos cuenta la autora del libro The Boom in Barcelona. El escritor mejicano declaró que: "Juan Goytisolo deserves to be included in the Boom for the subversive aspects of his trilogy of novels: Marks of Identity, Count Julian, and Juan the Landless. These novels include a violent demythification of 'Eternal Spain', a project that makes it akin to the SpanishAmerican works of the Boom"(17). La intencionalidad de romper con una idea de España que representa la opresión y el lado más oscuro de la colonización es lo que hace cercana la postura ideológica y de interpretación de hechos históricos de Goytisolo con muchos de sus compañeros de Latinoamérica. El Boom es un movimiento que intenta crear estética y estructuralmente un nuevo tipo de novela que hasta ese momento en Latinoamérica se caracterizaba por ser poco innovadora, de contenido plano y sobre temáticas que no suscitaban un interés especial en los lectores extranjeros. Estos autores abren paso a la experimentación y quieren romper con una visión provinciana de cada

\footnotetext{
${ }^{11}$ Carta publicada en Libre . Revista de crítica literaria. (1971-1972)
} 
uno de los países a los que pertenecen: "The aesthetic and political realms mirror each other. By using experimental narrative techniques, Boom novels undo the traditional linearity of the realist/regionalist novel written during the 50s and before" (The Boom 17). Tanto Goytisolo como Vargas Llosa intentan presentar una imagen distinta de sus países de origen. En el caso del primero lo lleva a cabo a partir de su trilogía Mendiola, que marcará un antes y un después en su narrativa y en el caso del segundo encontramos algo muy parecido con la trilogía que forman tres de sus primeras novelas: La ciudad y los perros, La casa verde y Conversaciones en la catedral. José María Oviedo la plantea en los siguientes términos: "Las revisiones y replanteos intelectuales de Vargas Llosa continuaron y se agudizaron en la década del 70, justo después de la publicación de Conversación, que visiblemente cierra un ciclo creador" (190). Se trata de un paralelismo que merece un espacio aparte en este estudio y que ahora no voy a abordar en profundidad, tan sólo quiero dejarlo aquí como idea a tener en cuenta y que retomaré más adelante en el capítulo segundo, dedicado a la autobiografía y biografía de ambos escritores.

Ahora voy a centrarme en los referentes ideológicos comunes de los dos autores. A finales de los años 60 y a principios de los años 70 se encuentran ambos muy identificados con los planteamientos que Sartre hace sobre la necesidad de que los escritores tengan un compromiso social y que sus obras sean un medio que ayude en la lucha contra las injusticias que se están cometiendo en esos momentos de la historia europea. Tanto Vargas Llosa como Goytisolo tienen en el filósofo y ensayista francés un referente ideológico. Es más, leyendo la obra ensayística de ambos autores podemos saber la evolución que se da en esa relación e identificación personal con el 
existencialismo francés. De los dos, será Vargas Llosa quien a lo largo del tiempo se desvincula de los postulados de Sartre tras leer y profundizar en la filosofía de Albert Camus:

La relación triangular Vargas Llosa/Sartre/Camus no sólo ayuda a entender las ideas literarias y las posiciones intelectuales que el primero ha ido desarrollando a lo largo de más de 30 años de actividad, sino que echa luz sobre cuestiones todavía más vastas, como la formación ideológica de un escritor latinoamericano, su posición frente a la cultura europea y, sobre todo, el gran tema de la responsabilidad moral de un intelectual ante las demandas de la historia y la política. (Oviedo 183)

Esta evolución tiene mucho que ver con los acontecimientos históricos del momento y con la transformación que va experimentando el pensamiento político que el escritor peruano tiene a lo largo del tiempo. Él mismo menciona cómo cambió su visión sobre Sartre en un ensayo que escribe en 1974:

Sartre es uno de los autores a quien creo deber más, y en una época admiré sus escritos casi tanto como los de Flaubert. Al cabo de los años, sin embargo, su obra creativa ha ido decolorándose en mi recuerdo, y sus afirmaciones sobre la literatura y la función del escritor, que en un momento me parecieron artículos de fe, hoy me resultan inconvincentes; son los ensayos dedicados a Baudelaire, a Genet, sus polémicas y artículos lo que me parece más vivo de su obra. Su figura moral en cambio, ha ido agigantándose siempre en mí, en las crisis y dilemas de estos años difíciles, por la lucidez, honestidad y valentía con que ha sabido enfrentarse, no sólo al fascismo, al conservadurismo y a las trampas burguesas, sino también al autoritarismo y al espíritu clerical de la izquierda. (Contra viento 220)

En este fragmento deja claro lo que admira del filósofo existencialista francés, su lucha contra los totalitarismos y los sistemas que impliquen una reducción de las libertades individuales. Vargas Llosa es un intelectual que rechaza cualquier régimen o gobierno que limite la libertad de las personas. Es uno de los principios que Vargas Llosa mantiene intacto a lo largo del tiempo y a pesar de su distanciamiento con Sartre, esa convicción permanece. El motivo de su alejamiento, como decía, es provocado tras el 
descubrimiento de la obra de Flaubert y también de los escritos de Albert Camus, al que llega a conocer personalmente en París.

Goytisolo mantiene también esa admiración personal por Sartre, que además se refleja en su obra. Lo conoce en Francia durante su exilio y publica en la recopilación de sus ensayos una entrevista con él. Se trata de una conversación que tiene lugar "tras la terminación de la reunión soviético-americana en la "cumbre" que tuvo lugar en 1971 y a la que hace referencia en el volumen VI de sus Obras completas. En esta entrevista se recoge la crítica que Sartre hace del sistema político soviético que "es el de una burocracia en el poder. Desafortunadamente, la mayoría de la población quiere conservar esta burocracia" (Obras completas VI 1531). Los intelectuales de ese país son quienes únicamente denuncian esa situación, pero se encuentran desvinculados del resto de la población por lo que su influencia en la opinión pública es nula, como también dice Sartre en la entrevista que le hace Goytisolo. Encontramos además una crítica a la clase obrera que concuerda con las reflexiones de muchos intelectuales y artistas del resto de Europa:

Los obreros, en la medida que ahora ganan más, no protestan, están satisfechos con el régimen, aprueban sus medidas; muchos aprobaron, por ejemplo, la intervención de los soviets en Praga. No hay, pues en la URSS actualmente una masa dispuesta a actuar como podría encontrarse en Europa occidental; no hay nada. (Obras Completas VI 1533)

Lo que se encuentra finalmente es una sociedad que tiene "aspecto de dictadura pequeñoburguesa" (Obras VI 1533). Esta crítica al sistema soviético provocó reacciones por parte de sectores de la izquierda europea occidental al considerar que con ella se estaban legitimando los excesos del sistema capitalista. Ante este ataque, el pensador francés respondió que "no nos parece válida la objeción de que denunciar el sistema de la URSS 
es sinónimo de hacerle el juego al capitalismo. Para nosotros es más importante en este caso decir la verdad que ocultarla" (Obras VI 1538). Al igual que en otros autores del momento, hay una total coherencia en la postura de Sartre ya que en ningún momento aceptaría el totalitarismo, viniera de donde viniera. Este posicionamiento es algo que también comparten Vargas Llosa y Goytisolo. Podría parecer poco significativa esta coincidencia de pensamiento entre ambos autores, pero es precisamente el hecho de que Vargas Llosa encuentre otros planteamientos filosóficos que le inspiren más, lo que hará que se comience a producir una separación entre la forma de escritura de ambos. Puede que Vargas Llosa centre más su forma de escribir en las cuestiones de la estética literaria inspirado por Flaubert. Sin duda, mantiene un punto de crítica social en su evolución literaria que de alguna forma estará presente en todas sus novelas, pero en nada es comparable con el activismo social que mantendrá el escritor español a lo largo de los trabajos que hace durante su extensa carrera literaria.

Hay una entrevista que se publicó en la revista Libre originalmente, en la que Goytisolo habla de la idea que tiene Sartre sobre la violencia y la revolución: "En el caso de Chile, por ejemplo, no creo en la posibilidad de llegar al socialismo por la vía legal. La violencia, cierta forma de violencia, es necesaria" (Obras VI 1539). Desde este posicionamiento, en la entrevista se hace alusión al papel que ha de tener el intelectual ante una situación así. Sartre piensa que un "intelectual revolucionario" ha de escribir algo más que poemas o libros. Ha de comprometerse con la revolución activamente. Y esto es lo que hicieron tanto Goytisolo como Vargas Llosa con la revolución cubana cuando esta comenzó. Hubo una identificación con la causa revolucionaria. También lo 
hace Vargas Llosa en su país cuando publica un ensayo titulado "Toma de posición” en el que apoya la actuación de la guerrilla en Perú:

El movimiento de guerrillas que ha estallado en la sierra peruana no constituye un fenómeno importado, aberrante o ajeno a nuestra realidad, sino que es la consecuencia natural de una situación secular que se caracteriza por la miseria, la injusticia, la explotación, el inmovilismo y el abandono en que nuestros gobernantes han mantenido siempre al país. (Contra viento 75)

Es una forma de justificar la causa que provoca la necesidad del uso de la violencia para garantizar la igualdad y los derechos de una parte de la población peruana que se ve continuamente oprimida por las clases dirigentes. Es ese espíritu del que habla Sartre y que como decíamos, lo encontramos tanto en Vargas Llosa como en Goytisolo. La violencia que ambos utilizan es, ante todo, la violencia de las palabras. Como bien señala Brad Epps: "Juan Goytisolo is an eminently violent writer" (1). El uso que hace del lenguaje es un arma certera. En este sentido, es inolvidable el discurso provocador que pronuncia ante los Reyes de España y los principales miembros del Gobierno de la nación con motivo de la entrega del Premio Cervantes en 2014:

Esa empresa de los caballeros andantes decía Don Quijote "deshacer tuertos y acudir a los miserables". Imagino al hidalgo manchego montado a lomos de Rocinante acometiendo lanza en ristre contra los esbirros de la Santa Hermandad que proceden al desalojo de los desahuciados, contra los corruptos de la ingeniería financiera o a estrecho traviesa, al pie de las verjas de Ceuta y Melilla que él tomó por encantados castillos con puentes levadizos y torres almenadas socorriendo a unos inmigrantes cuyo único crimen es su instinto de vida y el ansia de libertad. $\mathrm{Si}$, al héroe de Cervantes y a los lectores tocados por el ansia de su novela nos resulta difícil resignarnos a la existencia de un mundo aquejado de paro, corrupción, precariedad, crecientes desigualdades sociales y exilio profesional de los jóvenes como el que actualmente vivimos.

El discurso continúa, fiel al más puro estilo sartriano, con una reflexión sobre cuál es el papel del escritor en estos tiempos: "Las razones para indignarse son múltiples y el escritor no puede ignorarlas sin traicionarse a sí mismo. No se trata de poner la pluma al 
servicio de una causa por justa que sea, sino de introducir el fermento contestatario de ésta en el ámbito de la escritura". Ese compromiso con lo que es trascendente políticamente y con lo que ocurre en sus países de origen y en el mundo, es algo que podemos encontrar continuamente en la obra de ambos escritores. Son escritores comprometidos en el sentido más sartriano del término. Es cierto que podremos encontrar grandes diferencias en la forma de acercarse a distintos asuntos de la actualidad, pero estará presente en la narrativa y también en la obra ensayística de ambos.

Para continuar este análisis de las cuestiones que justifican el análisis comparativo del trabajo de ambos autores, es importante detenernos un momento en lo que representa el movimiento del postmodernismo y sus planteamientos teóricos. Sophia A. McClennend habla de la influencia de este movimiento en Goytisolo y otros autores latinoamericanos:

Goytisolo writes about his contact with French intellectuals, like Roland Barthes, in his memoir, Realms of Strife. Placing the advent of postmodernism within a certain time period in these areas is extremely tricky, but it is clear that writers in Spain and Latin America had been exposed to European and U.S. theories of postmodernism by the 1970s. (19)

Aunque se ha señalado que la inspiración en este movimiento que en otros autores españoles es posterior, en el caso de Goytisolo, no será así debido a la influencia que recibe de estos planteamientos durante su estancia en Francia. Linda Hutcheon describe el postmodernismo así: "is a contradictory phenomenon, one that uses and abuses, installs and then subverts, the very concepts it challenges -be it in architecture, literature, painting, sculpture, film, video, dance, TV, music. Philosophy, aesthetic theory, psychoanalysis, linguistics, or historiography" (2). Es una tendencia que surge con fuerza como contestación a las posiciones ideológicas más conservadoras del momento. Se trata 
de un ataque directo al liberalismo burgués. Es una forma de entender la creación literaria y artística que, como también nos dice Hutcheon, comienza en Europa y sigue en América del norte y del sur. Es un cambio en la forma de escribir, en la estética que evita la omnipresencia de un narrador en tercera persona para intentar conseguir un diálogo entre la voz narrativa y el lector. Esto mismo es algo que encontramos en muchas de las novelas de Goytisolo y Vargas Llosa. En partes de Coto Vedado el autor utiliza la segunda persona. Lo mismo ocurre en la obra de Vargas Llosa, La ciudad y los perros. También hay textos que no son lineales, sino que se caracterizan por los paralelismos y los saltos temporales en muchas de las novelas del escritor peruano. El hecho de poder tener en las obras de ambos a personajes que son tratados en muchos casos como protagonistas o como parte esencial de las historias que nos cuentan, enlaza bien con uno de los principios del postmodernismo que además es mencionado por Hutcheon en la siguiente cita:

The center no longer completely holds. And, from the decentered perspective, the "marginal" and what I will be calling the "ex-centric" (be it in class, race, gender, sexual orientation or ethnicity) take on new significance in the light of the implied recognition that our culture is not really the homogeneous monolith (that is middle class, male, heterosexual, white, western) we might have assumed. The concept of alienated otherness (based on binary oppositions that conceal hierarchies) gives way, as I have argued, to that of differences that is to the assertion, not of centralized sameness, but of decentralized community another postmodern paradox. (Hutcheon 12)

Lo que ayuda a nuestro análisis de modelos de masculinidad alternativa en el caso de las obras de los dos escritores, es precisamente el hecho de que éstos, siguiendo los principios del postmodernismo, nos ofrecen obras literarias en las que hay personajes que pertenecen a colectivos marginales, pero que son presentados como parte esencial de la trama. Estos personajes se alejan de la presencia de modelos masculinos que pertenecen 
al modelo hegemónico. Las obras de Goytisolo y Vargas Llosa ofrecen esa posibilidad de ver al Otro en mayor profundidad y con mucho más detalle: cómo son, cómo piensan, cuáles son sus antecedentes personales y familiares, sus dudas, sus ansias, etc. Es por tanto una opción para mostrar modelos alternativos, para incorporar nuevos puntos de vista, para dar voz a personajes que en otros momentos de la historia de la literatura han quedado en la sombra. Ambos están especialmente interesados en ofrecer nuevos espacios en sus textos, que den cabida a otras formas de ser. Sin esta opción sería imposible por ejemplo pensar en Reivindicación del conde Don Julián donde el autor se permite hacer una relectura de muchas de las figuras históricas de España. En el caso de La ciudad y los perros, encaja perfectamente esta nueva perspectiva que ofrece el posmodernismo. En el colegio Leoncio Prado, institución peruana que tiene como misión "producir hombres de verdad" para la sociedad de este país latinoamericano, encontraremos como Vargas Llosa entra en los rincones más oscuros para desvelar la diversidad, la heterogeneidad de quienes están allí como estudiantes y también como instructores, de forma que no todo es homogéneo y sin fisuras (ambas obras contienen en sus páginas un mapa humano diverso). Es importante tener en cuenta que para hacer la descripción de este grupo de personajes los autores hacen uso de la parodia como recurso narrativo. Es una forma de ser incisivo evitando la alusión directa en la narración de ciertos hechos que son de una alta sensibilidad social y política. Tenemos el caso de Goytisolo en su Reivindicación del conde don Julián, donde se produce la violación del personaje de Isabel la Católica por parte de las hordas musulmanas. En el caso de La tía Julia y el escribidor, Vargas Llosa nos cuenta en una de las historias radiofónicas lo que ocurre con los miembros de la guardia civil a quienes se les ha encomendado la misión de 
matar a un hombre negro por considerarlo salvaje. El recurso de la parodia se utiliza en otra de las historias de esta misma novela donde se relata la relación incestuosa entre un surfero y su bella hermana y lo que ocurre cuando la obligan a casarse con alguien que no quiere. Como nos dice Hutcheon, la parodia forma también parte del movimiento postmodernista porque es algo que ayuda a abordar temas que pueden resultar ofensivos para una parte de la población, y esto se consigue adoptando un tono más suave y humorístico.

En la novela Reivindicación podría resultar insultante para los lectores encontrar imágenes tan absurdas como la aparición de la reina Isabel la Católica como si fuera una mujer negra cubana bailando al ritmo de la música afrolatina. Todo este tipo de crítica a los símbolos más tradicionales de la nación está hecha desde el humor y desde el poder que tiene la parodia para enmascarar imágenes ofensivas.

El enfoque de muchas de las novelas, y más aún, de la obra ensayística de ambos autores, incorpora diversas perspectivas al más puro estilo del movimiento posmodernista ya que como señala Linda Hutcheon hablando de esta corriente, es una opción que permite teniendo como base la diversidad, tanto de personajes, como de temáticas e historias; se trata más de una poética que del seguimiento de una estructura creativa rígida en la que no tengan cabida posibles variaciones. En el postmodernismo se puede encontrar una estructura novelística fluida. Aparecen innovaciones formales que rompen con lo que se venía haciendo hasta ese momento. Hay un enriquecimiento en los estilos literarios que se nutren de la aparición de nuevos géneros que se basan en la hibridez, de tal forma que se eliminan barreras entre ellos y se entremezclan. 
Esta hibridez de géneros literarios está presente en obras como Coto vedado de Goytisolo o El pez en el agua de Vargas Llosa, donde se mezclan rasgos de la narrativa de ficción con el género autobiográfico. En el caso de El sueño del celta, Vargas Llosa se mueve entre el relato histórico y la novela de ficción. Creemos que no es descabellado decir que gran parte de la producción literaria y ensayística de Goytisolo y Vargas Llosa podría enmarcarse en este movimiento posmodernista. Son dos personas que conocen los aspectos que definen la marginalidad, el sentirse diferentes a los demás. Es así porque ellos mismos han traspasado las fronteras físicas de sus países. Son autores que viven en el autoexilio desde hace muchísimos años y ven desde la distancia lo que ocurre en sus lugares de origen. Su percepción de la no existencia de fronteras en su experiencia vital les hace trasladar esa visión a su producción novelística. Sus puntos de vista sobre el mundo serán muy diferentes al común de la ciudadanía ya que el hecho de abandonar sus lugares de nacimiento les llevará a vivir en otros países, otros continentes y otras culturas donde entran en contacto con otras personas, otras lenguas y otros planteamientos filosóficos. Es esa experiencia de diversidad la que enriquece sus vidas y por supuesto, se deja también entrever en su producción literaria. En Reinos de Taifas, Goytisolo habla de todo ese aprendizaje que le permite su estancia en Francia y en qué medida el contacto con la vida intelectual parisina es clave para su vida personal y como escritor: "la noche en que fui por vez primera al lugar en el que escribo estas líneas y conocí a un tiempo a Monique y Genet, dos personas que por vías y maneras distintas influyeron decisivamente en mi vida y cuyo encuentro desempeña en ésta un papel auroral" (1745).También habla de ello Vargas Llosa en El pez en el agua (2003) donde relata su experiencia parisina y en qué medida se ve influido por sus vivencias fuera de su 
país natal. Ambos autores son "hombres de mundo" que dejan de pertenecer a un solo espacio político y económico. La salida de sus respectivos países hace de ellos personas que adquieren una visión del mundo desde una perspectiva más global y por supuesto, esto se refleja directamente en sus obras.

En el momento del surgimiento de las repúblicas independientes de los países latinoamericanos que fueron colonias de la corona española, surge una forma de literatura propia del siglo XIX, cuyos textos se caracterizan por ser planos y lineales en el desarrollo y con una serie de personajes previsibles, ya que suelen representar a los sectores sociales que en aquella época leían, la burguesía incipiente que representaba la clase criolla ${ }^{12}$. Una de las cuestiones que encontramos abiertamente en las obras de Vargas Llosa y de Goytisolo, es que lo que era una excepción en los albores de la novela latinoamericana y podríamos decir también en la peninsular (salvo el caso de la picaresca), pasa a ser algo habitual en sus narrativas, de forma que se puede resaltar la importancia que adquiere la representación de la periferia social y económica, así como el hecho de dar voz y forma a personajes que normalmente no formaban parte de las novelas que se escribieron en el siglo anterior por ser considerados ajenos al modelo hegemónico de masculinidad. Ese modelo de masculinidad se basa en la presentación de los hombres como los únicos con capacidad de decisión, los que pueden controlar y de hecho controlan las leyes. Ejercen además un control sobre las mujeres, que son relegadas a un papel subordinado. La violencia es otra de las características que distingue

\footnotetext{
${ }^{12}$ Es raro encontrar autores que aborden el protagonismo de personajes polémicos, más bien es una gran excepción, tal es el caso de Augusto D’halmar en su obra Pasión y muerte del cura Deusto, un texto que es valiente porque aborda la homosexualidad de forma abierta en una época donde este modelo de masculinidad era totalmente rechazado. En el texto del autor chileno, no sólo se aborda esta cuestión, sino que además entra en contacto directo con la religión, ya que el protagonista será un cura que viene del País Vasco y que se enamora de un joven gitano en la Sevilla de esa época.
} 
esta percepción de lo que es realmente masculino. Se cuestionará la masculinidad de todo aquel personaje que demuestre sensibilidad ante las artes o la literatura. Seguidamente se exponen algunos de estos modelos de masculinidad que encontramos en obras Goytisolo y Vargas Llosa.

“¿Quién me puede culpar por haber querido hacer de él un hombre?” (267). Es el lamento del padre de Ricardo Arana, el Esclavo, personaje de La ciudad y los perros (1962) de Mario Vargas Llosa. Es un lamento que recoge toda una ideología, una forma de percibir la realidad, un concepto de género, una identificación con un modelo masculino que tiene como consecuencia la exclusión de otras formas de ser hombre; que provoca violencia, rechazo, y ridiculización de todo aquello que no cumpla con lo esperado por la sociedad. En esta novela del escritor peruano tenemos representados perfectamente modelos alternativos de vivir esa masculinidad, como señala R. W. Connell: "It has become increasingly clear that different masculinities are produced in the same cultural or institutional setting" (36). Su existencia es algo evidente, otra cosa es qué tratamiento recibe todo aquel hombre que no cumple con la máxima de ser heterosexual y poderoso, alguien que no encaje con el modelo patriarcal. También encontramos a personajes como Roger Casement, protagonista de El sueño del celta, que es homosexual. ${ }^{13}$ Es alguien que encarna perfectamente esa forma diferente de ser hombre, aunque la consecuencia de ello no es el éxito, sino todo lo contrario, el castigo por considerarlo un traidor. En este caso, el término traición va más allá de lo político. La

\footnotetext{
${ }^{13}$ En ella se aborda el relato del diplomático británico que alcanzó prestigio mundial tras hacer una investigación in situ y redactar dos informes que condenaban la actuación abusiva contra los derechos humanos del rey de Bélgica Leopoldo II en el Congo y otro para denunciar los abusos en esta misma materia por parte de la dirección de la empresa británica de recolección de caucho en los campos de la Amazonia peruana. Finalmente es condenado por traición a la corona británica tras ser descubierta por los servicios secretos su negociación con Alemania para obtener armas con el fin de organizar una revuelta armada de los grupos independentistas irlandeses contra el Imperio Británico. A pesar de esto, el detonante de su ejecución fue el hecho de su homosexualidad. (para evitar el leísmo)
} 
publicación de sus diarios personales en los que recoge sus experiencias homosexuales es lo que desata el rechazo social hacia alguien, que además de traicionar a la corona inglesa por su apoyo a la causa independentista irlandesa, ha traicionado el principio máximo de la sociedad patriarcal: la heterosexualidad que garantiza la reproducción del ser humano.

También son castigados varios personajes de otras novelas, como ocurre con el Esclavo en La ciudad y los perros. Ricardo Arana (el Esclavo) y Alberto Fernández (el Poeta) proceden de dos familias distintas, de distinto origen social; no obstante, ambas confían en el resultado que se obtendrá tras el paso de los hijos varones por el colegio Leoncio Prado. Son además los padres los que tienen una creencia ciega en el poder del internado militar para educar a sus hijos en lo que la sociedad espera de ellos como hombres. Estos dos adolescentes sufren antes de ser enviados al Leoncio Prado el rechazo de sus padres por no tener un comportamiento que se ajuste a las expectativas sociales en lo que respecta a las maneras que la sociedad espera de ellos como hombres. Son juzgados por hombres (sus padres, en primera instancia y por sus compañeros, más adelante) en todo momento. Como señalan Alsop, Fitzsimons y Lennon, para considerar la adquisición del estatus de hombre es necesario obtener la validación de otros hombres: los padres, los amigos; no cuentan las mujeres, el poder de lo masculino se construye sobre la negación de lo femenino.

En el caso de Goytisolo encontramos dentro de su obra modelos alternativos de masculinidad empezando por él mismo. En Coto vedado publica abiertamente su experiencia personal en su autoreconocimiento como homosexual. Cuenta muchas de sus vivencias personales y habla abiertamente de cuestiones tan personales como el abuso 
sexual al que es sometido por parte de su abuelo, o confesiones como ésta: "Desde la adolescencia, había comprobado con inquietud y sorpresa que, a diferencia de mis amigos y compañeros, la cercanía o intimidad con las mujeres no me procuraban la menor emoción" (170). Es una afirmación que nos pretende mostrar su experiencia personal al enfrentarse a su homosexualidad y la angustia que esta le producía: "La idea de ser tomado por un miembro de ese gremio objeto de un desprecio y aversión universales me llenaba de angustia y espanto" (Coto 172). Siente la presión social por ser de otra forma y también siente la presión que recibe por parte de su padre, alguien que censurará en todo momento su dedicación a la literatura. En su trilogía Mendiola, Álvaro, el niño que aparece en Señas de identidad y que finalmente es simbólicamente violado y matado en Don Julián, representa la evolución sexual del propio autor. quien desvela abiertamente la doble sensación: por un lado está el rechazo que siente el Álvaro de Señas de identidad, al ser abusado por su abuelo y por otro, la atracción que siente al sentir placer mientras mantiene relaciones sexuales otro hombre. Era una forma traumática de descubrir su homosexualidad. Se trata de un acto de sumisión que tiene especial relevancia en la obra. En Don Julián, Goytisolo escribe el relato del proceso de enfrentamiento personal a los miedos de la infancia y en particular al miedo de enfrentarse a algo que socialmente se cree monstruoso e inadmisible. Finalmente, él lo acaba aceptando aunque sin dejar de mostrar esa angustia y ese sentimiento de culpa que le invade por ser homosexual.

En ambos autores podemos encontrar, por tanto, referencias a ese temor al qué dirán, lo cual es la consecuencia de la presión social que perciben constantemente. Esa presión busca garantizar que no exista opción de ser hombre fuera de los márgenes 
establecidos dentro de un modelo hegemónico. Todo aquel que no cumpla con esos preceptos será recriminado y considerado como una mujer. Es esta sociedad patriarcal y machista la que identifica al género femenino como inferior. No olvidemos que, como señala Anderson, el discurso misógino genera desigualdad entre hombres y mujeres, y además, reproduce la homofobia y ese rechazo a hombres que actúan de una forma distinta al modelo heteronormativo. En cualquier caso, es evidente que hay muchas formas de ser hombre y podemos encontrar a lo largo de los textos de ambos autores varios ejemplos más, además de los reseñados aquí. La presencia de una gran diversidad de tipos de comportamiento masculino es una constante en la novela de ambos autores y estos son presentados como modelos alternativos de masculinidad: homosexuales, bisexuales, hombres que tienen sensibilidad artística, hombres que son sensibles a la injusticia social, hombres que no tienen problema al reconocer su admiración intelectual por mujeres de su tiempo y no temen mostrar abiertamente la importancia que ellas han tenido en su desarrollo personal e intelectual. Es el caso de la escritora y esposa de Goytisolo, Monique Lange o la tía Julia, en el caso de Vargas Llosa. De alguna forma, ellos son también hombres que pueden representar un modelo alternativo como tal por su experiencia de vida.

Esta representación de distintos modelos de masculinidad implicará también la representación de un modelo de nación. La relación entre el género y la nación es inseparable: "constructions of nationhood usually involve specific notions of both "manhood" and "womanhood" (1) tal y como nos plantea Nira Yuval-Davis. Esta es una cuestión que requiere un planteamiento extenso en el que no voy a entrar ahora. No podemos olvidar que Goytisolo y Vargas Llosa critican a sus naciones de origen y como 
vimos al comienzo de este ensayo, incluso proceden a "matar" esa idea de nación que consideran obsoleta, represora y limitadora para sus habitantes. En el caso de Goytisolo siempre se ha identificado ese proceso con su trilogía Mendiola; en el caso de Vargas Llosa, como nos dice Raymond Lesllie Williams, sus novelas muestran un gran descontento con su país natal, Perú. Creo que podríamos decir que otra trilogía que podría marcar una forma de expresar ese descontento es la que formarían: La ciudad de los perros, La casa verde ${ }^{14}$ y Conversaciones en la catedral. Gran parte de la crítica escribe sobre esta última novela como la que completa a las dos anteriores en esa visión negativa de su país.

Otro tema importante es el papel de la mujer en la vida de ambos y cómo incide en el desarrollo de su obra literaria. En el caso de Goytisolo, quien fue su mujer, la francesa Monique Lange, escritora y editora que trabajaba en Gallimart, la editorial más importante del momento en Francia por ser la que publicaba todo lo que producía la nueva corriente de pensadores de la filosofía existencialista. Ella fue quien facilitó que el escritor barcelonés pudiera conocer a los principales componentes de la intelectualidad francesa de los años 60. En el caso de Vargas Llosa, una de las mujeres claves en su vida fue su tía Julia, con quien llega a casarse. El hecho de tener que buscar trabajo para poder ser autosuficiente y poder vivir con ella le lleva a aceptar un puesto que le permitió poder leer una gran cantidad de libros que le abrieron una nueva visión del mundo y de la literatura, como nos cuenta en El pez en el agua. Ambas mujeres están presentes en sus obras, pero tanto Goytisolo como Vargas Llosa dedican una novela expresamente a Monique, el primero, y a Julia, el segundo. En el caso de Goytisolo hay un diálogo

\footnotetext{
${ }^{14}$ Raymond Lesllie Williams dice que "according to Mario Vargas Llosa, this complex novel with its many intertwining stories represented a type of "emancipation" from a variety of experiencies of different periods of his life". (39)
} 
literario que se desarrolla en varias novelas y especialmente en Ella. En el caso de Vargas Llosa, tenemos la publicación de La tía Julia y el escribidor, donde se desarrolla la historia que se ambienta en la ficción, pero de clara inspiración personal.

Como conclusión a lo que aquí se ha ido comentando diremos que, tras la lectura de la crítica reciente y los estudios sobre la generación del Boom en la novela latinoamericana, ambos autores pertenecen claramente a esa corriente. A pesar de ser un grupo mayoritario de escritores de América del Sur, no deja de existir una conexión con España, sobre todo por el apoyo editorial que reciben las novelas por parte de Seix Barral y la difusión que se consigue. Bien es cierto que esto no es motivo suficiente para hacer un estudio comparativo de las obras de ambos autores, pero es el germen para entender que ambos van a compartir una visión del mundo y también una forma estilística y estética en el desarrollo de sus trabajos literarios y ensayísticos. Tanto Vargas Llosa como Goytisolo están en continuo contacto con la realidad que les rodea y a partir de ella, darán lugar a una obra ensayística, que merecería una tesis adicional a ésta por la gran cantidad de temas que abordan, en muchos casos coincidentes. Goytisolo tiene una forma de escritura en la que aborda el tema de España desde una perspectiva que se acercará más a la visión desde las colonias que a la visión desde la metrópoli. Ya mencionamos en este capítulo como resalta este asunto otro de los principales autores del Boom, el mexicano, Carlos Fuentes. Goytisolo rechaza la España que llegó a tierras de América y destruyó las peculiaridades que hacían a ese continente distinto a cualquier otro. Goytisolo, al igual que Vargas Llosa reflejan esa actitud de supremacía que se ejerce sin pudor por parte de las naciones europeas que implantan por decreto forma de organización y explotación económica en territorios colonizados. 
También se puede decir que ambos autores se nutren de un movimiento filosófico, cultural y de cambio que se ve reflejado en sus obras. Hay momentos en que la colaboración entre ambos escritores es estrecha, especialmente en las luchas políticas de los años 60 y 70. No es difícil encontrar también paralelismos en sus narrativas como hemos podido ver a lo largo de este capítulo. Existe esa relación en la obra autobiográfica que en ambos es extensa e importante, con las diferencias propias que les caracteriza (esta cuestión se abordará en el siguiente capítulo de esta tesis). Creo que es difícil no encontrar algo de Goytisolo cuando se lee un texto de Vargas Llosa y viceversa, ante todo, porque ambos crean obras comprometidas que requieren de lectores activos. Como señala Belén Castañeda, refiriéndose a Vargas Llosa: "El papel del lector es, por consiguiente, un elemento básico en la concepción literaria de Vargas Llosa. Los recursos técnicos del escritor tienen como fin el estructurar y ordenar la materia creativa de manera que el lector rellene por sí mismo los vacíos de la obra" (355). Y es claramente extensivo a la obra del escritor español también, quien hace a sus lectores cómplices en ese esfuerzo de análisis de una realidad distinta a la que tradicionalmente se ha podido encontrar en otros momentos de la literatura, tanto peninsular como de América Latina. 


\section{CAPÍTULO II}

La vida se encuentra con la ficción: La hibridez en la narrativa de Goytisolo y Vargas Llosa

En este capítulo vamos a centrar el análisis en la obra autobiográfica de Mario Vargas Llosa y de Juan Goytisolo. Sin duda que será difícil distinguir en muchas ocasiones si estamos hablando de obras de ficción u obras autobiográficas porque en ambos autores tenemos textos en los que, a pesar de ser un relato de ficción, encontraremos algunos hechos que también ocurrieron en su vida real. Estamos ante obras de autoficción. Sería imposible abarcar todos los elementos autobiográficos presentes en sus novelas. Por eso, vamos a centrarnos en el análisis de sólo algunas de ellas. En el caso de Juan Goytisolo, al igual que hablamos de la trilogía Mendiola como punto que marca un antes y un después en su trabajo novelístico; podríamos también mencionar que hay una secuencia parecida en sus relatos sobre su vida; se trata de lo que podríamos denominar la trilogía autobiográfica que estaría formada por: Coto vedado, En reino de taifas y Carajicomedia. La primera, recoge su vida personal y sus relatos familiares; la segunda, nos da a conocer su posicionamiento político e ideológico, así como su concepción sobre cuál es la finalidad de la literatura para la sociedad; en la tercera será donde finalmente Goytisolo aborda de una forma mordaz y satírica su homosexualidad.

En el caso de Mario Vargas Llosa no encontramos muchas obras que podamos calificarlas como puramente autobiográficas. El autor peruano opta más por incorporar elementos de su vida a muchas de sus novelas de ficción. En muchas ocasiones, podemos encontrar aspectos de su vida y de su pensamiento en cada una de las novelas que escribe. Como señala Belén Castañeda al hablar del autor peruano: "No es posible, por 
consiguiente, separar la vida y la biografia del escritor de su obra literaria" (350). En este capítulo trabajaremos con una de sus obras fundamentalmente: El pez en el agua, obra en la que, como señala Eduardo Muslip, "el texto se acerca más al diario personal que a las memorias." (109). En esta obra Vargas Llosa nos ofrece en una estructura narrativa de cajas chinas, propia de su estilo literario, lo que sería el relato de su vida familiar y amorosa y en capítulos alternos escribe sobre todo lo relacionado con su carrera política y las razones del porqué de su posicionamiento político.

Antes de entrar en profundidad en el análisis de todas estas obras nos vamos a detener en el marco teórico que nos permite poder hablar del género autobiográfico. Es un género literario que ha sido reconocido como tal muy recientemente. Sin duda, el teórico más conocido es Philippe Lejeune y su ensayo On Autobiography. Es precisamente en esta obra donde encontraremos argumentos a la hora de definir las características que conforman dicho género. Vamos a empezar por una de sus primeras definiciones cuando nos aclara qué se puede considerar autobiografía cuando dice:

Acknowledging autobiography to be a complex and unstable category, historically speaking, and eschewing any pretense to an essentialist or idealist objective, Lejeune proposed the following working definition of the genre: "we shall define autobiography as the retrospective prose narrative that someone writes concerning his own existence, where the focus is his individual life, in particular the story of his personality. (On Authobiography viii)

Se trata, como bien dice esta cita de una categoría que difícilmente fue considerada como un género en sí hasta hace poco más de medio siglo que aparece el trabajo de Lejeune. La importancia de este ensayo radica en proponer argumentos sólidos para hacer del género lo suficientemente importante como para que sea considerado su análisis de forma diferenciada con respecto a otras formas de narrativa. 
Al abordar el estudio de obras autobiográficas Lejeune se enfoca en cuatro aspectos: la forma del lenguaje, el tema tratado en la obra, el rol que toma el autor en el texto y por último menciona la posición del narrador. La mayor parte de las autobiografías que vamos a analizar en este capítulo son obras de carácter narrativo en las que en ocasiones tenemos incluso duda de si estamos ante una novela de ficción o ante un texto autobiográfico. De sobra es conocido que ambos autores huyen de las normas y de las estructuras formales tradicionales. Eso también ocurre en las novelas que analizaremos más adelante. Con respecto al tema tratado en la obra, Lejeune nos menciona que pueden ser "individual life, story of personality (4). Atendiendo a estas dos modalidades, las obras de Juan Goytisolo van a abarcar ambos tipos de temas. Podemos decir que Coto vedado y En los reinos de Taifa son las dos narrativas más autobiográficas. En la primera, Goytisolo inicia el texto en la primera página diciendo: “En mi caso- vástago, por ambos lados, de una común, ejemplar estirpe burguesa- , los informes tocantes a mis antecesores obtenidos durante mi infancia no exceden de la primera mitad del siglo XIX" (9). A partir de este punto se inicia un viaje por su historia familiar que nos ayudará a ir conociendo mejor el contexto social que marca la vida del autor. En la segunda, En los reinos de Taifa, también tenemos todo un relato vívido que incorpora, además, historia de pensamiento. En esta obra podemos conocer detalles del Juan Goytisolo adulto, el escritor maduro, el pensador y el político. El autor barcelonés explica su reacción ante hechos que tienen lugar en Europa y que impactan en su identificación con el comunismo internacional: "La rebelión de Budapest y su aplastamiento por los tanques soviéticos sacudieron entre tanto la firmeza de nuestras convicciones. Monique militaba aún en el PC francés y yo seguía frecuentando en París a 
algunos camaradas de Luis, miembros de la agrupación universitaria barcelonesa" (33). Son muchos los momentos en esta novela en los que pone el foco en las reuniones que mantuvo durante su momento de activismo político en el Partido Comunista. También son muchas las ideas que desarrolla sobre lo que para él es la literatura y el papel del autor: "Los ataques dirigidos a un escritor prueban muy a menudo que su obra existe, hiere las convicciones morales o estéticas del lector-crítico y, por ello mismo, provocan su reacción: en corto, entablan una relación dinámica con él” (1468). Hasta la publicación de Carajicomedia (2000), no podemos decir que tengamos ese segundo tipo de historia de la personalidad de la que nos habla Lejeune. Es precisamente una obra que es escrita en plena madurez literaria y personal. Su homosexualidad es públicamente conocida y será en este texto donde podremos descubrir su parte más íntima. Es un acto de confesión que además está escrito de una forma muy original y mordaz. Es un texto satírico en el sentido más puro del término. El humor con el que se habla explícitamente de las relaciones sexuales con hombres y el uso de una simbología puramente católica, nos permiten descubrir a un Goytisolo muy personal y provocador. Hace mofa de la religión católica en la que fue criado y educado y en la que la idea de pecado es lo que marca la vida sexual de cualquier persona que se salga de los cánones dictados por esta confesión que asocia las relaciones sexuales exclusivamente con la procreación y nunca con el placer sexual.

En el caso del Mario Vargas Llosa, no cabe duda de que su novela autobiográfica por excelencia es El pez en el agua. Se puede entender como una memoria personal y política, tal como dijimos al comienzo de este capítulo. Para llegar a un público más amplio, Vargas Llosa no revela su intimidad, evitando asimismo una posible 
vulnerabilidad. Ya veremos cómo Vargas Llosa prefiere dejar en manos de sus personajes de obras de ficción ese Yo más íntimo y personal. Se queda por tanto en la historia de un personaje de ficción y no tan claramente en un texto en el que el Yo sea el mismo autor. Hay varios ejemplos de este tipo de obras, siendo una de las más relevantes La tía Julia y el escribidor, obra de ficción, pero con unos claros apuntes autobiográficos por el papel que toma el narrador en el texto. Se trataría de la tercera categoría del relato autobiográfico, según Lejeune. Hay ocasiones en que "the author (whose name refers to a real person) and the narrator are identical" (On Autobiography 4) En el caso de La tía Julia habrá un personaje llamado "Varguitas" que será el que represente al propio autor: “-O sea que los escritores son unos muertos de hambre. Quiere decir que toda la vida vivirás fregado, Varguitas. Desde que se lo había oído a Javier, ella también me llamaba Varguitas" (2054). Si en El pez en el agua de Vargas Llosa es dónde podemos encontrar una clara identificación entre personaje y narrador, en el caso de Goitysolo, sucede lo mismo en Carajicomedia, en la que, en un juego parecido al de La tía Julia, un personaje ficticio traído de la historia de España, Fray Burgeo, será quien haga las veces del autor:

En el salón morisco de Alhama, inaugurado según la Dueña por Napoleón Chico y la emperatriz Eugenia, me sentaba a veces a platicar, después de mis ejercicios y preces, con algunos colegas asiduos, como yo, del lugar.

(No voy a describir éste pues el inevitable J.G. barcelonés lo hizo por mí en uno de sus libros y resultaría muy engorroso a estas alturas enmendarle una vez más la plana). (90)

No obstante, este monje es identificado continuamente con el autor barcelonés a lo largo de ese texto.

La cuarta y última categoría que menciona Lejeune es la posición del autor en los textos autobiográficos. Son dos los posicionamientos posibles: "a. the narrator and the principal character are identical; b. retrospective point of view of the narrative" (4). En 
todas las obras de ambos autores hay una visión retrospectiva y en todas ellas se nos relatan hechos ocurridos en el pasado de los autores. Como comentamos anteriormente, en ocasiones narrador y autor coinciden, pero en algunas ocasiones, ambos quedan algo más confundidos, más camuflados. Esto es lo que nos puede hacer dudar a la hora de hablar de un texto puramente autobiográfico al modo de los que se solían escribir por muchos personajes en el siglo XIX. En este caso, Juan Goytisolo y Mario Vargas Llosa, huyen en cierta medida de hacerse ver como personajes de importancia histórica, su forma de escribir les hace mucho más modestos y aunque se trate de dos de los "grandes" de las letras en español, no será porque se hayan autocalificado como tales. Saber sobre los miembros de la familia, sobre los acontecimientos históricos de los países en los que respectivamente nacieron; sobre la evolución de sus posicionamientos políticos a lo largo de su vida; sobre sus relaciones con otros personajes del ámbito de la literatura, el arte o la política; o sobre sus relaciones amorosas es, por supuesto, echar una mirada retrospectiva. Son ellos mismos los que relatan dichos hechos en primera persona, por lo que la identificación entre autor y narrador se da continuamente. De ahí que podamos clasificar como claramente autobiográfica la mayor parte de las novelas que analizamos en este capítulo. No obstante, y huyendo de una definición pura de autobiografía, es importante recordar que "the autobiographical novel includes personal narratives (identity of narrator and protagonist) as well as "impersonal" narratives (protagonists designated in the third person); it is defined at the level of its contents" (Lejeune 18). De ahí que en algunos de los textos la identidad del protagonista queda algo confusa o se puede pensar que se trata de un personaje de ficción. Eso sí, este personaje mostrará una serie de anclajes que conectarán sus experiencias ficticias con otras reales que vivió el 
autor. Es el caso de Fray Burgeo en Carajicomedia cuando habla de que hay ciertas cosas que las hace igual que un tal J.G. (Juan Goytisolo), o en momentos en que menciona amigos del personaje que "curiosamente" coinciden con amigos del autor de la obra. Como dice Lejeune: "If I write the story of my life without mentioning my name in it, how will my reader know that it was I? It's impossible for the autobiographical vocation and the passion for anonymity to coexist in the same person" (20). Aparecen esos personajes ficticios, pero en muchas ocasiones, los autores de las obras no dejan de ofrecer pistas para que podamos identificarlos con ellos mismos. Es precisamente por ello que, aunque se pretenda conseguir el total anonimato, es imposible cuando se trata de escribir novelas del género autobiográfico, incluso cuando la primera persona es utilizada en la narración: "The first person always conceals, then, a secret third person, and in this sense all autobiography is by definition indirect" (Lejeune 33). A pesar de que estemos leyendo sobre acontecimientos personales, hechos que han marcado la vida de cada uno de los personajes; o vivencias que marcaron un rumbo determinado. Se trata siempre un relato de forma indirecta, contado como si se refirieran a una tercera persona. Esto hace que en ocasiones podamos asistir al uso de diferentes personas en un mismo trabajo. Juan Goytisolo lo hace continuamente en sus textos autobiográficos. Hay veces en que esa forma indirecta se manifiesta en el uso del tú para marcar la distancia que permite una mayor perspectiva ante un hecho: "Una noche en la que has fingido sentirte más borracho de lo que estás realmente, volverás pies atrás camino del muelle y treparás al zaquizamí en donde se acuesta tu amigo: tus deseos de tumbarte a su lado, de sentir el cercano calor de su cuerpo han sido más fuertes que tu timidez e inhibición física" (Coto Vedado 225). Es habitual encontrar el relato en segunda persona cuando Juan Goytisolo habla de 
cuestiones que se acercan a su lado más íntimo, especialmente, cuando habla de sus deseos sexuales. Sin embargo, en el relato autobiográfico de Vargas Llosa no se produce esta equidistancia; como mucho, tal y como señalamos anteriormente, pone en acción a personajes ficticios que mantienen relación con aspectos que ocurrieron en su vida real como es el caso de "Varguitas". Se trataría de una forma de ampliar la distancia y así no exponerse tan a las claras ante sus lectores en lo que a sus vivencias más íntimas se refiere. Ese sello personal en cada uno de los textos es algo habitual ya que como bien dice Jean Starobinsky: "In a narrative in which the narrator takes his own past as theme, the individual mark of style assumes particular importance, since to the explicit selfreference of the narration itself the style adds the implicit self-referential value of a particular mode of speaking" (74). La personalidad de Juan Goytisolo y de Vargas Llosa se refleja en sus obras autobiográficas y cada uno de ellos imprimirá su sello personal en ellas.

El relato autobiográfico es un ejercicio personal difícil para un autor ya que como expone Staborinsky: "autobiography is not a simple recapitulation of the past; it is also the attempt and the drama of a man struggling to reassemble himself in his own likeness at a certain moment of his history. This delivering up of earlier being brings a new stake into the game" (43). A partir de esta cita incorporamos al análisis el elemento del tiempo en que se escribe una autobiografía. Se trata de un ejercicio que requiere la madurez personal del autor para enfrentarse al reto de escribirla. No todos estamos preparados en cualquier momento de nuestra vida para revisar nuestro pasado y menos aún para desarrollarlo en forma de texto y exponerlo públicamente tras su publicación. A partir de ese momento en el que se adueñan del texto las personas que lo leen, se hace que nuestra 
imagen quede en manos de los lectores. Es un medio para conseguir que el lector se identifique de una forma personal con el autor. El lazo se estrecha desde el momento en que el escritor y el lector comparten momentos íntimos y en algunas ocasiones, secretos que fueron guardados durante años incluso para las personas más cercanas al escritor.

La carta que escribe Juan Goytisolo a Monique Lange es un texto explícitamente autobiográfico; también forma parte del dominio público la relación de confrontación que tuvo Mario Vargas Llosa con su padre. Ambos autores han hecho partícipes a sus lectores de estos hechos personales. Se produce así una relación más íntima, de mayor complicidad y en algunos casos de identificación personal con el autor. Esa complicidad genera fidelidad en el lector pues aumenta el interés por leer lo que escribe alguien que ha tenido vivencias parecidas. De alguna forma es una terapia personal y como bien dice Bertrand Cohler:

It is inevitable that the reader seeks a connection between his or her own life and that of the author. Readers most often find some similarity between the person whose personal account they are reading and their own life. For example, gay and lesbian readers look to the personal accounts of other gay-life writers in order to help us understand the meaning of sexual desire in their own lives, to learn about how others have dealt with issues of coming to terms with a gay identity, how they have disclosed their gay identity to family and friends, how they have dealt with stigma at school and in the community and, alas, how gay men have managed issues related to the AIDS pandemic. (6)

Se refiere a personas homosexuales que tienen que luchar para vencer todo un sistema de control social que hace de su orientación sexual un obstáculo para poder tener una vida social normalizada, pero también podemos pensar en personas que no sean homosexuales y que encuentran en los textos autobiográficos situaciones personales que les hacen identificarse con el autor. Por supuesto que cada autor tendrá un nivel de exposición 
pública mayor o menor ${ }^{15}$. En el caso de Vargas Llosa y Juan Goytisolo, la diferencia es importante y es algo que recogeremos en las conclusiones de este capítulo. Independientemente de este matiz importante, ambos comparten con sus lectores vivencias personales y confesiones que ayudarán no sólo a conocerles mejor en lo personal, sino también, a entender el porqué de la publicación de gran parte de sus obras de ficción. Como dice Diane Jorklund: "Autobiographies can help us make sense of our lives and give voice to thoughts and feelings that we also may have had" (ix). Se produce una conexión lector-autor en una dimensión más personal y es un acto consciente como también señala esta autora. Se conoce el riesgo que corre un autor cuando se expone personalmente de forma tan abierta a sus lectores, de ahí que Vargas Llosa y Juan Goytisolo lo hacen de forma distinta. En el análisis que hacemos de los textos en esta tesis, es precisamente la subjetividad que se puede encontrar en muchos de esos libros lo que más aportará a nuestro trabajo. Esto lo comenta Diane Jorklund cuando escribe: "This concern over the unreliability and subjectivity of autobiographies is well-advised for those who would use them for factual data on topics such as criminal behavior or historical events. But as a record of prevailing ideas about self, the subjectivity of autobiographies is precisely what is interesting" (9). En el análisis literario de un autor es muy importante poder conocer esos elementos subjetivos que nos van a permitir entender mejor su obra y el porqué de la publicación de la misma.

\footnotetext{
${ }^{15}$ Cualquier texto autobiográfico implica una exposición personal al público. Diane Jorklund lo expresa perfectamente cuando dice: "By writing an autobiography, they are engaging in social act. Because they expose their personal lives to criticism, they attempt to give not only meaning to their lives but also value. We can see how they use rhetoric (sometimes adeptly, sometimes awkwardly) to persuade their readers that they have admirable traits and have made important choices in their lives for acceptable reasons. What traits they claim to possess and how they justify the choices they have made can tell us about extant values and ideas during the eras in which they wrote" (xi).
} 
Las autobiografías son útiles porque nos ayudan a conocer mejor no sólo al autor a nivel personal, sino también el porqué de que se hayan escrito algunas de sus obras; las razones por las que se ha elegido una determinada localización geográfica o la elección de un espacio histórico temporal en el que estarán ambientadas. Son claves que podemos encontrar en este tipo de obras porque como dice Jorklund:

The self- interpretations of autobiographers can tell us about changing ways of thinking and talking about the self. Their stories are not strictly personal and unique; they consider their own lives and organize their experiences in the light of general ideas they have learned about what it means to be human. Like all of us, their ideas about themselves have been significantly shaped by their culture and era. $(x)$

Son por tanto espacios de lectura que nos permiten conocer el contexto histórico y cultural en el que se movieron y vivieron los escritores y de qué forma éste, influye en ellos a nivel personal y en su obra. Sería imposible entender el ataque de Juan Goytisolo al canon tradicional de la literatura española si no leemos en Coto Vedado fragmentos como éste:

Muy significativamente, los libros sobre los que pronto me arrojaría serían, casi sin excepción, de autores extranjeros: leídas en francés o en las mediocres traducciones que llegaban bajo mano de Buenos Aires, las novelas que devoré entre mis dieciocho y veinticinco años no incluían a un solo autor en castellano. La instrucción dispensada en el colegio no solamente me hizo aborrecer nuestra literatura --- convertida en un muestrario de glosas pedantes y exegesis hueras --sino que me persuadió también de que no había cosa en ella cuyo conocimiento mereciera la pena. (120)

El autor español hace una crítica feroz contra esas obras del canon tradicional en su Reivindicación del conde don Julián. También Vargas Llosa nos ofrece datos del contexto histórico, social y educativo en el que se desarrolló como adolescente en El pez en el agua donde nos desvela el significado que tiene en la sociedad limeña el colegio Leoncio Prado al que él asistió como cadete militar: 
Entrar en un colegio militar, cuyos alumnos recibían grados de oficiales de reserva, resultaba una buena antesala para un aspirante a la Escuela Naval.

Así que cuando, al terminar el segundo de secundaria mi padre me matriculó en una academia del jirón Lampa, en el centro de Lima, para prepararme el examen de ingreso al Leoncio Prado, tomé el proyecto con entusiasmo. Ir internos, vestir uniforme, desfilar el 28 de julio junto a los dos cadetes de la Aviación, la Marina y el Ejército, sería divertido. Y vivir lejos de él, toda la semana, todavía mejor. (114)

Tras leer este fragmento podemos entender mucho mejor el significado de su primera novela, La ciudad y los perros ya que es en el Leoncio Prado donde se desarrolla toda la trama y en la que toman vida los personajes que Vargas Llosa inventa. Por lo tanto, las autobiografías establecen un hilo de conexión con la obra de ficción de ambos autores. Unas obras nos llevan a las otras y viceversa y esto ocurre porque en esos trabajos autobiográficos como dice Diane Jorklund: "They are an amalgam of cultural ideas, scruples, art, imagination, rethoric and self presentation"(x). Ese conjunto de experiencias, de ideas, de imaginación, de hechos familiares y personales servirán en momentos de inspiración para poner en marcha un proyecto literario que toma forma de ensayo o novela con el tiempo.

A partir de este momento nos vamos a detener en las obras que comentamos al comienzo del capítulo haciendo un análisis que nos permita entender mejor no solo la personalidad, sino también el porqué de la existencia de un fértil trabajo literario desarrollado a lo largo de toda una vida. Comenzaremos por la obra autobiográfica de Juan Goytisolo. Como ya se comentaba en el capítulo primero de esta tesis, es difícil poder encontrar una pureza de estilo que ayude a una clara clasificación en cuanto a género literario se refiere. Si algo distingue la obra y vida de Juan Goytisolo es precisamente esa huida de la pureza entendida como algo inamovible. El traspaso de las 
fronteras es algo común y la atracción por el mestizaje, no sólo el humano, sino también

el de los estilos literarios. Esto es lo que dice al respecto Juan Francisco Ferré

Como JG, cuyo empleo tanto de los modos de "ficción" como de los de "dicción" complica notablemente la recepción y favorece toda suerte de malentendidos y confusiones (tanto textuales como extra textuales) al situarse en las lindes genéricas o en el intersticio de unos y otros, allí donde se solapan ilusión referencial y estrategia retórica o elocutiva. (51)

No tendría sentido que Juan Goytisolo mantuviera un respeto a la norma pura puesto que él nunca lo hizo y precisamente utiliza el lenguaje como una forma para transgredir lo establecido $^{16}$ Es una forma de escritura que mezcla momentos que nos pueden llevar a parte de su obra de ficción y también en el sentido opuesto, de la ficción a la realidad, como dice también Ferré: "Lo autobiográfico de su obra, y no sólo de esta novela, se comunica por esta vía con los elementos ficcionales que también la constituyen, y viceversa, en una suerte de arabesco o anillo moebiano que no admite fáciles soluciones" (54). En este caso se habla de Coto Vedado que sería la primera novela autobiográfica del escritor español. Sí se establece un paralelismo entre su obra de ficción y su obra autobiográfica. ${ }^{17}$ En la primera obra, el autor centrará su relato en el momento de su vida que va desde su infancia hasta los años 50 que es cuando conoce a la que será su esposa, la francesa Monique Lange. Es un volumen que nos hace un recorrido por la relación con

\footnotetext{
${ }^{16}$ Goytisolo se posiciona claramente en contra de todos los elementos históricos y culturales que han alimentado ese pensamiento intolerante y que ha tenido siempre como consecuencia la exclusión de todo aquel que no se ajusta a un modelo caracterizado por la unidad de comportamiento, de pensamiento, de religión o de visión moral de la sexualidad. El autor necesita eliminar ese universo cultural, ese imaginario social. Lo hace cuando habla de su país de origen, España. La forma en la que escribe es también una forma de reivindicación y por supuesto, de transgresión. Hay una continua vulneración de las normas básicas de puntuación en ese desafío a la implantación de un modelo único que tiene como objetivo unificar y excluir a cualquier texto que no cumpla con las estrictas normas gramaticales. Esta cuestión del lenguaje no es algo que aparezca de forma continua en su obra autobiográfica, pero sí que podemos asistir a una lectura en la que en un momento dado no sabemos si estamos leyendo algo referido al Yo y contado por él mismo, o bien se trata de algo que más tiene que ver con la ficción que con la realidad.

${ }^{17}$ Cuando hablamos de la trilogía de obras de ficción nos referimos a la trilogía Mendiola que está compuesta por Señas de identidad, Reivindicación del conde don Julián y Juan sin tierra.
} 
sus familiares, la trágica pérdida de su madre y la existencia de personajes clave de la familia que hicieron que su vida tomara el rumbo de la escritura. También aborda la difícil relación con su padre y por supuesto, los inicios de sus sentimientos de deseo homosexual. El comienzo de Coto vedado nos hace pensar que el hecho de hacer una reflexión sobre el origen familiar no tiene mayor trascendencia. En sus palabras, esta obra comienza diciendo:

Espulgar genealogías se reduce a descubrir, dirá el narrador socarrón del Petersburgo de Biely, la existencia final de linajes ilustres en las personas de Eva y Adán. Fuera de este hallazgo capital e incontrovertible, las arborescencias y frondosidades de los troncos materno y paterno no suelen prolongarse-con excepción quizá de unas cuantas familias de aristócratas--- a ese limbo original pomposamente conocido por la noche de los tiempos. (9)

Realmente lo que nos intenta decir es que no hay ningún ánimo de grandeza en el hecho de escribir un libro en el que nos hable de sus orígenes familiares. En su caso, como señala, su familia pertenece a la "ejemplar estirpe burguesa" (9), cuestión que será clave para poder entender la razón de muchas de sus luchas personales en el futuro; sobre todo, teniendo en cuenta lo que significa pertenecer a esta clase social en una España que estaba justo en plena contienda de una Guerra civil cuando él nació. Abundar en los excesos de su familia es algo que le inspirará a la hora de dar lugar a su creación narrativa, así lo dice por ejemplo al mencionar los abusos de su bisabuelo contra los esclavos negros que trabajaron en la hacienda propiedad de su familia en Cuba, algo que le permite no sólo identificarse con la revolución castrista ${ }^{18}$, sino que además inspiró parte del texto Juan sin tierra. El autor lo cuenta así:

El proceso revolucionario cubano, iniciado unos años más tarde, sería vivido así, íntimamente, como una estricta sanción histórica a los pasados crímenes de mi linaje, una experiencia liberadora que me ayudaría a desprenderme, con la

\footnotetext{
${ }^{18} \mathrm{El}$ abuelo de Juan Goytisolo fue dueño de tierras en Cuba y tuvo esclavos para la explotación de las mismas.
} 
entusiasta inserción en él, del pesado fardo que llevaba encima. La misiva incluida en el último capítulo de la novela que cierra mi trilogía es auténtica si bien, por razones de adaptación novelesca, introduje algunos cambios al transcribirla. (11)

Las dos citas anteriores de Coto vedado son claros ejemplos de lo que significa el ejercicio autobiográfico que hace Juan Goytisolo en esta y las otras dos novelas de su trilogía de vida. Como señala Ferré:

El soporte autobiográfico de la obra de JG (su componente "autodiegético") sería entendido como primera fase de la empresa de deconstrucción emprendida por ella misma: crear, y no sólo recrear, el referente imprescindible, la figura, la personalidad, los hechos o acontecimientos, las versiones, en suma, sobre las que va a actuar en su obra narrativa y a partir de los cuales entender las transgresiones y subversiones que va a someterlas implacablemente. (48)

Cobra sentido que esta primara obra sea publicada en el año 1985, un momento en que ya hay una madurez creativa en el autor barcelonés; además, ya ha sido publicada su trilogía Mendiola que es la que marca, según gran parte de la crítica, un punto de inflexión en su evolución narrativa. Bien es cierto que muchos de los aspectos que Juan Goytisolo comparte en Coto vedado también aparecen en Señas de identidad. Ya lo comenta Randolph Pope:

En el caso de Juan Goytisolo, el autor de la autobiografía española contemporánea de mayor éxito tanto entre el público en general como entre los críticos, una autobiografía en dos volúmenes, Coto vedado (1985) y En los reinos de taifa (1986), la autobiografía vino al final de una larga serie de novelas de un claro contenido autobiográfico. (26)

La novedad es que la primera se escribe en un momento de madurez personal, tras haber podido conocer la reacción de la crítica ante la publicación de sus primeras novelas y al haber cerrado un ciclo narrativo con la trilogía Mendiola que se verá explicado claramente a través de la escritura de los tres textos autobiográficos de los que estamos hablando en este capítulo. Como dice Ferré en la cita anterior, se puede decir que 
encontramos una explicación al porqué de la existencia de las tres obras narrativas tras la lectura de estas tres obras autobiográficas. En esta primera novela autobiográfica el autor catalán hace una confesión personal hasta el límite y detalle más íntimo. Hablo del abuso sexual que sufrió durante su infancia por parte de su abuelo materno. El relato que hace de ese momento es realmente espeluznante, pero a la vez es un momento necesario a la hora de entender la cuestión de la orientación sexual que aparece de forma continua en la obra narrativa de Juan Goytisolo. La homosexualidad se muestra como algo que es considerado pervertido por la sociedad ultracatólica de la España franquista y también por el propio padre de Juan Goytisolo, a quien define con respecto a este tema de la siguiente forma:

La fobia visceral de mi padre a los homosexuales-cuyo símbolo execrable encarnaba su suegro-alcanzaba a veces extremos morbosos: había referido con gran satisfacción a José Agustín—y éste se había apresurado a repetírmelo-que Mussolini mandaba fusilar sin contemplaciones "a todos los maricones". Aunque por aquellas fechas yo no tenía la más remota sospecha de mi sexualidad futura, la noticia, en vez de exaltarme, me llenó de malestar. (105)

Lo más sorprendente de la denuncia del abuso pederasta de su abuelo es que tan lamentable vivencia se transformó a la vez en el detonante para obtener una prueba más de su deseo sexual hacia los hombres. Además, este hecho le hizo ser consciente de que él no quería ser como su abuelo, él quería vivir esa homosexualidad sin necesidad de ocultarse ante los demás y llevar a cabo abusos como los que él, como nieto, sufrió. La forma en la que llega a esas conclusiones es expresada así en la obra por Juan Goytisolo:

La idea de seguir sus huellas, de resignarme también a una existencia miserable y desecha fue el mejor antídoto de mis dudas y vacilaciones el día en que, de forma no enteramente imprevista, me hallé en la situación antinómica de vivir una intensa relación afectiva con Monique y descubrir una felicidad física ignorada hasta entonces con un albañil marroquí inmigrado temporalmente a Francia. (106) 
Lo ocurrido con su abuelo es la causa que finalmente le lleva a esta reflexión sobre la necesidad de no sucumbir a esa trampa de ocultar el deseo sexual y martirizarse psicológicamente ante esta evidencia. Es una idea que puede parecer difícil de entender. Goytisolo es una de las víctimas de la pederastia ejercida por su abuelo, y aun así, el escritor va más allá de ese espeluznante hecho; como señala Ribeiro de Menezes: "In this regard, the opposing blocs of family members serve as a metaphor for Goytisolo's rebellion against authority and his establishment of a dissident position" (22). Seguir los pasos de su familiar le llevaría a la misma miseria moral, por eso huye de esta opción y toma un camino muy distinto, un camino que no sólo marcará su vida, sino también el curso y desarrollo de su obra. Si no hubiéramos conocido este acontecimiento, difícilmente podríamos entender algunos textos de su narrativa. Es por ello que Goytisolo llega a confesiones muy íntimas, lo que provoca una mayor exposición pública de su persona. A pesar de la extrañeza que puedan causar los hechos que narra en su obra, Goytisolo expone abiertamente su pensamiento para darnos a conocer cómo fue su evolución personal y eso nos ayudará a entender mejor sus relatos. Menezes habla de cómo el hecho de hacer público su dolor, hará que el vínculo con quien lo lee es más intenso y cercano:

The writing of his autobiography is, for Goytisolo, a serious inquiry into the establishment of a dissident, homosexual identity. While he is aware of the pitfalls of the enterprise, his aim remains the structuring of a message - a particular narrative or metaphorical 'frame' that will painfully but beneficially enlighten his life - and its communication to a readership with whom he adopts a quasiconfessional relationship. (13)

Se produce por tanto una identificación personal, una unión y una complicidad entre el Juan Goytisolo escritor y sus lectores. A través de este nivel de intimidad es muy probable que, como decíamos anteriormente, se produzca una identificación de vivencias 
entre quien lo lee y ha experimentado cosas semejantes a las que relata el autor. Sin lugar a dudas, en el terreno de lo personal, la obra autobiográfica de Juan Goytisolo va mucho más allá en lo íntimo que la obra de Vargas Llosa. También es cierto que el desarrollo de la obra narrativa de Juan Goytisolo va en paralelo a esta obra autobiográfica.

En el caso de su segunda obra dentro de esta trilogía autobiográfica, En los reinos de taifa podemos asistir a todo un testamento del Juan Goytisolo político y del escritor. Bien es cierto que en esta obra se menciona su homosexualidad, pero es ante todo, un trabajo en el que podemos conocer de primera mano sus movimientos en París durante sus reuniones con el comité de Partido Comunista de España, así como sus contactos a nivel intelectual con el núcleo de pensamiento de la capital francesa a raíz de haber conocido a Monique Lange. Ella trabajaba en la editorial Gallimart, la más importante durante los años 50 y 60 en Francia. De su mano pudo tener contacto directo con Camus, con Sartre, con Simone de Beauvoir y Jean Genet. Todos ellos son su "brújula intelectual", su inspiración a la hora de analizar y ver el mundo que le rodea. Como dice Angel Loureiro:

Three strands in particular will be woven into his authentic identity: sexuality, politics and writing. On each of those fronts, Goytisolo breaks with his past, and those ruptures narrated in En los reinos de taifa, almost simultaneously: his assumption of homosexuality; his definite rejection of Marxism as a form of understanding and changing the world; and his transition from being a passive victim of Spain's dictatorship and its cultural-historical constrictions to an aggressive attitude that, presiding over his fiction since Reivindicación del conde don Julián (Count Julian), leads him to ransack the cultural and political fabrications of Spain and to adopt the Spanish language as his only and true "fatherland". (104)

En los reinos de taifa, novela publicada en el año 1986, tratará temas sobre su orientación sexual, pero, ante todo, como hemos dicho, habla sobre su posicionamiento político y su reflexión sobre la finalidad de la escritura. Atendiendo al segundo tema, en 
esta novela, Juan Goytisolo nos va a dar muchos detalles sobre su activismo político. Un activismo clave para poner en marcha en el país galo un movimiento que permitiera ver la situación política de ausencia de libertad y total injusticia que vivía España durante la dictadura franquista. El autor lo comenta así en la obra:

Al instalarme provisionalmente con Monique en su apartamento de la Rue Poissonnière abrigaba el designio, tantas veces discutido con Castellet y Elena de la Souchère, de crear una tribuna de discusión común a la oposición interior y el exilio, abierta a las corrientes literarias y políticas de la cultura europea. Mi primera idea en aquel quince de septiembre de 1956 en el que, sin saberlo, iniciaba un alejamiento de decenios de Barcelona y España, había sido proponer a Mascolo la organización de un comité de intelectuales antifascistas franceses solidarios de tal empresa. (16-17)

Su activismo político es fundamental en aquel momento y su intención de crear un movimiento intelectual europeo contra las acciones del dictador Francisco Franco era uno de sus principales objetivos. Esta empresa le lleva no sólo a contactar con intelectuales de la capital francesa y otros países europeos, sino también a comunicarse directamente con el exilio español en el país vecino de España. Describe así este momento:

En las primeras y ajetreadas semanas de mi estancia en París entré igualmente en contacto con algunos exiliados españoles y viajeros procedentes de la Península situados entonces, en su mayoría, en la órbita del PCE: Tuñón de Lara, Antonio Soriano, dueño de la librería española de la Rue de Seine, Eduardo Haro Tecglen, Ricardo Muñoz Suay, Alfonso Sastre y Eva Forest, Juan Antonio Bardem. A los pocos días de mi llegada, Mascolo me introdujo al despacho de Maurice Nadeau, director de Les Lettres Nouvelles, para que le expusiera mi idea de una revista en castellano destinada a romper el cerco de la censura: primera de una larga serie de iniciativas al respecto que concluyeron de ordinario, después de discusiones inútiles e interminables, vetos, exclusiones, enfrentamientos, con el carpetazo y olvido del proyecto, de puro cansancio, no sin haber provocado antes entre los participantes en el mismo unos sentimientos de encono y amor propio herido difíciles de cicatrizar. (51-57)

Juan Goytisolo es un hombre comprometido con la tarea de desprestigiar al régimen franquista español y no sólo lo hizo a través de Reivindicación del conde don Julián, la obra más demoledora escrita contra esa idea de una España ultra católica y fascista. Hace 
un ataque feroz a esa España que detesta y denuncia. Escribe la obra con el expreso deseo de iniciar un nuevo momento que le permita ser sí mismo. Se trata de una muerte con esperanza, la esperanza de inaugurar un tiempo nuevo:

Augurio de una vida mejor y más libre, lejos de la funesta península y de su aletargada fauna: con aguda y enigmática sencillez: sedativa diana que inaugura el nuevo día, compensación y antídoto del brutal despertar: apostado en el chaflán como de costumbre, fuera de tu campo de observación. (Reivindicación 90)

Gracias a la lectura de la segunda obra de su trilogía autobiográfica, podemos entender el porqué de un trabajo tan demoledor a nivel narrativo en lo que a crítica política del régimen franquista se refiere $\mathrm{y}$ que tantas reacciones en contra produjo tras su publicación, poniendo incluso en peligro su propia vida. Juan Goytisolo nos cuenta En los reinos de taifa todo el proceso político que pone en marcha en la capital francesa para poder dinamitar y generar todo un movimiento intelectual y político a nivel europeo con la intención de ejercer presión sobre el gobierno del dictador Franco y así, debilitar el Régimen para restaurar la democracia perdida tras el golpe de estado de 1936. Al igual que otros muchos intelectuales latinoamericanos y franceses, Goytisolo siente una gran atracción por la revolución de Cuba al ser la primera que había sido impulsada por el pueblo contra el poder del dictador. En un mundo dividido en dos bloques ideológicos, Goytisolo, en su continua atracción por los más desfavorecidos y marginados, tomará partido activo en los movimientos más progresistas y pretenderá poner su grano de arena en la defensa de un mundo sin injusticias sociales. El veía en Cuba un claro ejemplo de lo que podría y debería ocurrir en España para acabar con el régimen:

La perspectiva que presentía era tan clara como ingrata: el Régimen duraría lo que durara la estampa odiosa de su creador. El año que siguió a esta conclusión melancólica busqué en Cuba, de forma compensatoria, la llama de una revolución milagrosa con sus promesas de libertad y de justicia. (861-863) 
Con el paso del tiempo y tras varios viajes a Cuba, Juan Goytisolo también nos va a contar cómo aprecia un deterioro en la isla del Caribe y empieza a darse cuenta de que lo que para él era un símbolo de esperanza, empezaba a mostrar indicios que apuntaban hacia una dirección que más tenía que ver con un régimen autoritario que con una revolución popular que trajera la libertad y la justicia social:

La estancia en Cuba, justificada por el trabajo de guionista en el ICAIC y rica de acontecimientos políticos y personales, no respondió esta vez a mis expectativas ni entusiasmo: la paulatina degradación del proceso revolucionario, la inquietud de los escritores e intelectuales que frecuentaba, las primeras ratas mensajeras de la plaga que años después haría presa de toda especie de inconformismo y conducta impropia eran demasiado visibles como para que pudiera ignorarlas. Lleno de dudas sobre la viabilidad y condición deseable del modelo cubano respecto de la sociedad española, volví a Europa para encontrarme con una dura pero pertinente respuesta a mis vagarosas propuestas tercermundistas. (932-936)

Podemos ver una evolución en su planteamiento y activismo político. Goytisolo reflexiona sobre cuestiones políticas y literarias, al mismo tiempo que habla sobre su orientación sexual. Goytisolo lo menciona expresamente así: "La dicotomía existente entre vida burguesa e ideas comunistas, afectividad e impulsos sexuales -cuyos bruscos, devastadores ramalazos sufría de vez en cuando durante mis correrías nocturnas- sólo podría superarse, pensaba, en la vorágine de una escalada revolucionaria en la que aquélla perdiera su razón de ser" (633-635). Su situación personal es una pura contradicción y una lucha no sólo en lo personal. ${ }^{19}$ También en lo político padece esa contradicción que le hace enfrentarse a su origen burgués, alguien que en definitiva, ha tenido una vida cómoda y que su experiencia política se produce más en los círculos de poder y no tanto en la política de bases. Su propia esposa le recuerda que es difícil poder saber lo que sienten las personas que son víctimas de la pobreza y la injusticia cuando

\footnotetext{
${ }^{19} \mathrm{El}$ mantiene una relación intensa con Monique Lange y a la vez tiene experiencias con otros hombres. Es una formad de vivir el deseo emocional que le une a la autora francesa y el deseo sexual que le lleva a vivir intensamente su homosexualidad.
} 
uno no ha vivido esa situación personal nunca. Podemos decir por tanto que En los reinos de taifa nos permite conocer en profundidad la evolución del pensamiento y compromiso político del autor de Barcelona y por supuesto, nos ayuda a entender parte de su obra narrativa. Si Coto vedado nos puede ayudar a entender mejor lo que ocurre en Señas de identidad; En reino de taifas nos ayudará a comprender el porqué de la existencia de Reivindicación del conde con Julián. Se puede decir que hay paralelismo entre las dos trilogías.

Antes de pasar al tercer libro autobiográfico de esta trilogía que comentamos aquí, es importante señalar que la cuestión de la sexualidad, como hemos dicho antes, también se presenta de forma explícita En los reinos de taifa. Podríamos decir que es una cuestión transversal en esta trilogía y tiene sentido, ya que la sexualidad es algo que define toda una forma de vida y de actuación en cualquier persona. La sexualidad de Goytisolo hace de él un disidente ya que se separa del modelo de masculinidad hegemónico aceptado socialmente. Ese proceso de escritura y lo que ocurre más adelante es contado por Goytisolo en el capítulo seis de En los reinos de taifa:

Una sensación de ingravidez excepcional, como un súbito cambio de presión en cabina, envolvía los trámites y formalidades del vuelo en un nimbo impreciso de irrealidad. Liberado del peso que me abrumaba, tenía la impresión de actuar bajo el influjo sutil de la grifa. La angustia de los últimos días, consagrados a la penosa redacción de la carta y preparativos del viaje, había disminuido poco a poco a partir del instante en que, de modo irreversible, había confiado mi destino al buzón. (3543-6)

Era un acto en que se materializaba a través de la palabra algo que Monique posiblemente ya sospechaba. Esa carta forma parte de esta obra de Goytisolo y también estará presente en la novela de Monique Lange, Las casetas de baño. Linda Gould Levin habla sobre esta obra diciendo lo siguiente: 
La observamos comprensiva de su necesidad de expiar el pasado esclavista de su familia; irritada por su ausencia; incómoda cuando él vuelve a casa después de hacer el amor con un argelino; incapaz de sentir como él la pasión por la música beréber y los ritos de los derviches de Konya; celosa, descontenta, conmovida ante la imagen del amante analfabeto que apasiona a su marido; atraída al mundo de los parias pero dolorida al reconocer que se han convertido en su rival. El hecho de que narre la novela en tercera persona, creando así cierta distancia entre el ser que ha vivido los eventos y las emociones que describe y el ser que los relata, no impide que se transmita con fuerza e intensidad toda la carga de sus diversas reacciones. (820)

En esta obra Monique Lange inventa un personaje que en realidad es ella, se trata de una mujer francesa de la Bretaña que se casa con un hombre español que tiene pasión por toda la cultura árabe. Se trata de un escritor que se siente atraído por los marginados y que mantiene relaciones sexuales con hombres, la mayor parte de ellos son árabes y a la vez, obreros. En la obra de Monique se relatan parte de las vivencias que ella tuvo con Goytisolo, así como su visión personal sobre la relación entre ambos. Estaba profundamente enamorada y a la vez reconoce que fue un marido ausente. El autor barcelonés hablaba de lo que él pensaba al haber enviado esa carta de confesión sobre su homosexualidad a su mujer y se preguntaba por lo que ella habría estado pensando: “imaginaba, aprensivo, su sorpresa ante la carta, las imprevisibles reacciones a la lectura de su contenido, su desconcierto o pánico frente a la exposición de un problema que, aunque barruntado por ella, iba a cegar bruscamente su horizonte e interponerse abrupto entre los dos" (3549-51). Aunque lo sospechaba, la carta corroboró lo que sospechaba. En el terreno de lo personal, éste es el principal hecho que podemos resaltar del texto autobiográfico de Juan Goytisolo.

Es precisamente la lealtad entre ambos tras este momento de su relación, lo que hace de Monique una persona clave en la vida del autor. La buena relación tras la ruptura matrimonial no impide la continuación de la relación de amistad y amor con ella. De 
alguna forma, la forma en que ella acepta la homosexualidad de su marido da a Goytisolo energía para sentirse bien consigo mismo por su honestidad al reconocerse abiertamente homosexual ante quién más le quería. Es probablemente esa fuerza la que le hace escribir una obra tan atrevida como Carajicomedia, de la que hablaremos seguidamente.

Tendremos que esperar hasta el año 2000 para que se publique la que podríamos considerar la tercera novela de esta trilogía autobiográfica de Juan Goytisolo, tal como señala Jonathan Loesberg: "Por eso, la reciente Carajicomedia se nos presenta como una pieza central, fin de fiesta formal y obra a todas luces definitiva y maestra" (74). Se trata de un texto muy interesante por su forma de escritura ya que utiliza la sátira para hablar abiertamente de personajes de la vida real que pasaron por la vida del autor. Tiene un toque de humor y por tanto, también de sátira al utilizar la nomenclatura con que la religión católica nombra a los santos para hablar de estos amantes. El lenguaje del libro es el que utiliza oficialmente cualquier religioso o católico, pero en el libro adquiere un segundo significado que se referirá a las prácticas homosexuales. Es más, podemos decir que esta obra trata prácticamente de forma exclusiva sobre la homosexualidad. De ello habla Loesberg:

Desde el principio de su gestación la obra retornaba al territorio de lo autobiográfico para encontrar su asiento en la vivencia más inmediata y privada del autor. JG se propuso inicialmente elaborar un recuento completo y pormenorizado de sus numerosas amistades magrebíes. Visto el escaso interés literario del proyecto original, de índole exclusivamente memorística, JG decidió integrar tal catálogo de amantes en una estructura híbrida de creciente complejidad textual, y desplazar su propia figura a un segundo plano narrativo, de manipulador en la sombra, en favor del excéntrico personaje del pére de Trennes: protagonista heterónimo y proteico de narración a quien se le traspasa descaradamente la morosa relación de ligues y la responsabilidad autoral de los manuscritos. (71-72) 
El hecho de elegir a un cura como narrador del libro tiene mucho que ver con el espíritu disidente y ante todo con la postura crítica que Goytisolo ha tenido a lo largo de su obra contra la religión católica. Es de sobra conocido lo importante que ha sido el papel jugado por esta confesión religiosa en la condena de la sodomía lo largo de la historia. ${ }^{20}$ En España, además, la religión católica estaba absolutamente mezclada con el poder político de la dictadura de Franco y, por tanto, ejercía el poder mediante sus postulados en contra de las relaciones homosexuales. En la descripción del personaje del pére Trennes podemos leer así: "Sobre la mesa de su despacho junto al Kempis de nuestro tiempo, se erguía con todo la estatuilla de un efebo griego. Gabriel, Cucú y yo andábamos intrigados, con una curiosidad aguijonadora y un tanto perversa por los rebozos y conchas del personaje. ¿Entendía? Dese luego que sí o, como recordé yo citando a Lorca, estaba perdiendo el tiempo" (14). La religión ha sido una de las principales responsables de control social hasta que en el siglo XIX se produce el traslado de esta función a otros sectores de la sociedad. A pesar de ello, en España, sigue siendo el poder religioso el que controla y reprime a todas aquellas personas que mantienen relaciones homosexuales. Goytisolo, en su Carajicomedia transforma en santos católicos a todos y cada uno de los amantes masculinos que recuerda y homenajea en el libro. Cuando el personaje protagonista, fray Burgeo va a comenzar a hablar de ellos, dice así:

\footnotetext{
${ }^{20}$ Como señala Mark D. Jordan: "Sodomy was invented by medieval theologians" (2). Se trata de una palabra que tiene gran importancia para la Teología cristiana en occidente. El autor sitúa el origen de este vocablo en siglo XI y menciona al teólogo Peter Damian como el responsable de su utilización como categoría que calificaba pecados y culpas. Se trata de una palabra que sufre un proceso de abstracción a lo largo de la historia y se la desdota de su contenido semántico real:“To abstract an essence from a proper name is to reduce the person named to a single quality. All that you need to know about the Sodomites is that they practiced Sodomy. In this way, abstraction from a proper name is deeply connected with the project of essentializing persons. A term like Soomy suggests, by its very grammatical form, that it is possible to reduce persons to a single essence, which can then be found in other persons, remote from them in time or place"(42). Es precisamente la religión católica la que más utiliza esta técnica en el uso de palabras.
} 
Conforme a sus decires, se refugió como los antiguos anacoretas en las fragosidades de la Mauritania Tingitana, acompañado de varios santos de recia y acrisolada virtud, con quienes corea las preces canónicas y se entrega a muchos y fervorosos ejercicios de devoción con ánimo de edificar a los jóvenes y encarrirarlos por las Anchas Vías del consuelo y la gracia. (26)

Prácticamente todos los hombres que menciona son de origen árabe. Es conocida su atracción por la cultura árabe y lo que para el autor español representó la expulsión de los musulmanes de España tras la llegada y conquista del último reino nazarí de Granada por parte de los Reyes Católicos. En ese tono transgresor propio del autor barcelonés, hará un repaso por un santoral compuesto por casi doce hombres, número cercano al de los doce apóstoles de Jesucristo. Sus nombres son: Mohamed, Buselham, Lajdar, Abdalá, Zinedín, Kitír, Abdelkader, Ahmed, Omar y Alí. Todos ellos coinciden en que son de origen árabe pero también en el hecho de pertenecer a la clase social de los oprimidos. Este es un motivo para que él adquiera la personalidad de un religioso católico que procura así ayudar para que estas personas que son víctimas de su entorno social, salgan de sus miserias y de su pobreza. Surge aquí ese espíritu solidario que Goytisolo siente hacia los oprimidos y por supuesto, esa atracción por lo sórdido, por los ambientes urbanos más deprimidos. Además, hay un uso perverso de la interpretación de la historia que pretende justificar decisiones de carácter político y económico. Se hace un uso interesado del relato histórico para así, dar cobertura a intereses que nada tienen que ver con el bien común. Hay una parte de la sociedad española que demoniza a los árabes que estuvieron en la Península y justifica su expulsión. Sin embargo, nos encontramos que más adelante, algunas de estas personas, cambian su punto de vista y justifican la colonización del norte de África en los años 50, con la idea de salvarles de la ignorancia a la que se han visto sometidos tras tener que haberse ido del continente europeo. 
Es como dice Aurora Morcillo "Spanish Orientalism is utilized by both traditional and progressive intelectuals" (263). Goytisolo se identifica sin duda con esa primera corriente de arabistas que ensalzan la aportación de la cultura árabe en la historia de España y cómo su influencia no sólo marca el destino de un país, sino el de todo un continente y una civilización. Ahora bien, dicho esto, también es importante señalar que para este autor lo que adquiere importancia en su idea de lo oriental es esa visión romántica que ve a esta cultura como lugar donde el placer y la sensualidad son algo que forma parte de su imaginario. En la descripción que hace de cada uno de estos "santos", además de su clara visión falocéntrica, está como elemento común el que todos son hombres de rasgos duros y muy varoniles: "la fiereza de unos bigotes arrechos que se torcían y apuntaban como las bayonetas de un áscari hindú" (63); o cuando al hablar de Katir dice así: “Argelino de la región de Tremecén, casado y padre de numerosa prole, tenía unas facciones de feriante gitano o dueño de una caseta de tiro al blanco" (47); o el caso de "Ahmed era uno de esos visitantes episódico: su rostro de centurión y la llama de su cirio votivo correspondían al Código de la Santidad y el encuentro fue fructuoso para ambos" (55).

De nuevo, el lenguaje es un elemento de provocación. Hace de la blasfemia la forma de expresión de este texto porque con ello está utilizando su forma de escritura para criticar y castigar el lenguaje religioso que en muchas ocasiones ha ocultado tras de sí, las más perversas realidades y los más oscuros hechos. Las palabras, al igual que hizo en Reivindicación, son una forma de ataque. Se puede considerar un texto satírico porque hace una crítica mordaz a la religión y a su interpretación de la sexualidad humana. Hay un fragmento en el que se habla del valor de la virginidad en las santas católicas y se 
presenta a una de esas vírgenes sorprendida y seducida por su clítoris, órgano sexual femenino cuya única función es la del deseo. Vuelve a presentar la hipocresía social promovida por la iglesia católica cuando escribe esto:

Me agradaba encerrarme en la alcoba con mi espejo de cuerpo entero y mientras, fuera, decenas y aun centenares de devotos gemían y oraban de hinojos y se daban golpes de pecho, yo examinaba mi botoncillo y su linda caracola de nácar, enamorada de la nitidez de sus líneas, acariciándolos con la yema de los dedos hasta humedecerme de amor. (143)

Goytisolo presenta a la religión como un elemento que ha ejercido un control feroz sobre el comportamiento sexual de los seres humanos y desmonta su careta para mostrar el lado más humano de ésta. Quita ese halo de santidad para transformar a las vírgenes en mujeres y a los santos en hombres que practican su sexualidad sin ningún tipo de represión. Tras toda la experiencia de vida del autor y tras muchas de sus decisiones, no teme en absoluto la crítica que pueda recibir por parte de ese sector social que hace de la religión el escudo tras el que ocultar sus mayores perversidades. Se denuncia así a una parte de la España ultra católica que ha extendido su poder y control mucho más allá de la dictadura de Franco. Se trata de desmontar toda una maquinaria moral de control en la que la religión ha sido el eje inductor y la que se ha encargado de la elaboración de una doctrina que acabará haciendo que el sentimiento de culpa impida el ejercicio libre de algo tan humano como la sexualidad. Carajicomedia ataca directamente a todo ese sistema al igual que lo hace Juan sin tierra. Es una obra que tiene conexión con la tercera parte de la trilogía Mendiola. La religión también forma parte de la crítica que se hace en esta tercera parte y la homosexualidad es un elemento clave del argumento.

Todas estas obras tienen un carácter contestatario y guardan un cierto resentimiento a los rasgos que han caracterizado la cultura española. Él es un exiliado por 
motivos ideológicos, y como bien señala Loureiro: "one should ask why the most searching autobiographies in nineteenth - and twentieth-century Spain have been written by exiles. Perhaps it is a matter of historical responsibility, in sum" (184). Esa distancia física e ideológica queda reflejada en estas tres obras autobiográficas de Goytisolo que nos sirven en gran medida para tener una visión más clara de lo que era como persona y lo que inspiró el desarrollo del resto de su obra narrativa.

Vamos ahora a detenernos en Mario Vargas Llosa. Como dijimos en la introducción de este capítulo, vamos a analizar principalmente una de sus novelas, El pez en el agua aunque hemos incorporado algún comentario sobre La tía Julia y el escribidor. A diferencia de Juan Goytisolo, no ha tenido que lidiar con su orientación sexual. Ambos autores sí que van a coincidir en que son exiliados de sus respectivos países de origen, aunque en el caso de Vargas Llosa, ese exilio político se produce tras la amenaza que recibe por parte del gobierno del dictador Fujimori de arrebatarle la nacionalidad peruana a consecuencia de su enfrentamiento político y denuncia internacional de los excesos del gobierno del mencionado presidente. Sí que podemos decir que hay todo un manifiesto político en la obra ensayística de Vargas Llosa donde se expone más abiertamente a sus lectores en lo que a sus planteamientos de ideología política se refiere. Sin embargo, en sus asuntos personales controla más qué contar y cómo contarlo. Por supuesto que su vida personal tiene una traducción directa en lo que ocurre en su narrativa. La forma autobiográfica vargasllosiana es definida por Jacques Soubeyroux de esta forma:

Si admitimos el argumento del carácter necesariamente autobiográfico de cualquier novela, que correspondería a cierta "experiencia personal" del autor, hay que subrayar sin embargo que la utilización de elementos autobiográficos y la 
implicación personal del autor en el texto son muy variables de una novela a otra: hay grados y formas distintas en la autobiografía vargasllosiana. (99)

Este es el motivo por el que, aunque centrándonos en su novela autobiográfica por naturaleza, también hemos comentado algo sobre La tía Julia que oficialmente se considera un texto de ficción. El pez en el agua (1993). Es un texto que conserva la huella del autor peruano por la estructura en la que está escrita. Aunque se trata de un solo volumen, podemos decir que contiene dos libros en uno. Siguiendo la habitual estructura de las cajas chinas, al leerla encontramos en desarrollo paralelo dos historias totalmente distintas, aunque ambas están relacionadas con el autor. Comienza con el relato de su infancia, cuando él estaba haciendo quinto de primaria en la ciudad de Piura. A partir de aquí, irá hilando en capítulos alternos los acontecimientos personales y familiares del autor. En el capítulo dos de la novela nos encontramos con un Vargas Llosa que acaba de cumplir los 51 años y que su recorrido como escritor es más que conocido y popularmente admirado. Es a partir de este momento cuando se relata el interés que de pronto atrapa al escritor con respecto a la situación política de su país: "Lo que no aparecía ni por asomo era la actividad que, por capricho de la rueda de la fortuna, monopolizaría mi vida los próximos tres años: la política" (38-39). Se produce a partir de este momento del libro el desarrollo en paralelo de los dos aspectos de la misma persona: el aspecto familiar y personal que comenzará en el capítulo 1 dedicado a la controvertida figura de su padre; y la otra parte del libro en la que se hablará de su papel en la política, como se recoge en la cita anterior.

Hay muchos aspectos de su vida personal que van a aparecer en estas memorias y que también lo tendremos en parte de su obra narrativa. Su padre es una figura que marca un antes y un después en su vida personal. En todo momento aparece el reproche hacia 
alguien que estuvo desaparecido durante diez años y que de pronto vuelve a aparecer en su vida dándole un vuelco absoluto. En la primera página del libro dice: "Era una larga historia que hasta ese día---el más importante de todos los que había vivido hasta entonces y, acaso, de los que viviría después---me había sido cuidadosamente ocultada por mi madre, mis abuelos, la tía abuela Elvira—la Mamaé---y mis tíos y tías, esa vasta familia con que pasé mi infancia" (11). El papel que juega la familia en la vida de una persona es esencial para su desarrollo personal y por supuesto, en el caso de un escritor, marca también lo que será su evolución como autor. Recibe por parte de la familia de su madre el gusto por la lectura: "El abuelo era aficionado a la poesía—mi bisabuelo Belisario había sido poeta y publicado una novela $-\mathrm{y}$ me enseñaba a memorizar versos de Campoamor o de Rubén Darío y tanto él como mi madre (que tenía en su velador un ejemplar de los Veinte pomas de amor y una canción desesperada, de Pablo Neruda, que me prohibió leer) me festejaban esas temeridades preliterarias como gracias" (22-3). Su paso por Bolivia donde fue destinado su abuelo durante un tiempo le hace pasar por un colegio religioso. A esa educación religiosa seguía la que recibía en casa; su abuelo es uno de los que más le impulsaron en su habilidad de escribir poesía, un tiempo que recuerda el autor como el origen de su afición a la creación literaria.

La sensación de bienestar que tenía hasta ese momento con la familia de su madre, se rompe bruscamente con un viaje a Lima en el que conocerá a su padre, lo cuenta así: "Las dos cosas que decidirían mi vida futura y que ocurrieron en ese año de 1946 solo las supe treinta o cuarenta años después. La primera, una carta que recibió un día mi madre. Era de Orieli, la cuñada de mi padre" (32); y más adelante, en el segundo párrafo dice: "La segunda fue un viaje de pocas semanas que había hecho mi mamá a 
Lima, en agosto, para una operación menor. Llamó a Orieli y esta la invitó a tomar el té. Al entrar a la casita de Magdalena del Mar donde aquella y el tío César vivían, divisó a mi padre, en la sala. Cayó desmayada" (32). A partir de ese momento, él recoge en estas memorias que su vida cambió y la aparición de su padre tendrá consecuencias que nunca olvidará. Vargas Llosa dice sobre su padre: "Tenía una sonrisa falsa, congelada en la cara. Mi desconcierto se debía a lo distinto que era este papá de carne y hueso" (33); a lo que añade: "Tenía el sentimiento de una estafa: este papá no se parecía al que yo creía muerto" (33). Desde este momento, serán muchos los acontecimientos narrados en los que la figura paterna aparece como el mayor obstáculo al que él tiene que enfrentarse durante su infancia. Este momento también trajo enfrentamientos con su madre: "Yo le contestaba a gritos que ese señor no me importaba, que no le quería ni lo querría nunca, pues a quien quería era a mis tíos y a mis abuelos. Esas escenas le amargaban y la hacían llorar" (60). A esto, se añade la descripción de momentos en los que vivió violencia contra su madre y contra él mismo por parte de su padre. Todo ello truncó una vida placentera con la familia materna.

Vargas Llosa marca un hito por la forma en que nos cuenta las cosas que ocurren en su vida. Lo hace mediante una narración exacta de los hechos; no procede a una interpretación psicológica de los mismos. Es importante mencionar esto porque, como decíamos anteriormente, esta novela de Vargas Llosa se acerca más a lo que sería considerado un diario personal. A lo largo de los capítulos que relatan esta parte de su vida familiar y sus experiencias amorosas y personales se marcan momentos claves en su vida: la decisión de que vaya a estudiar al colegio de cadetes Leoncio Prado que es interpretado por Vargas Llosa como su entrada en la edad adulta: "Hasta que entré al 
Leoncio Prado, en 1950, se desvaneció la inocencia, la visión candorosa del mundo que mi madre, mis abuelos y mis tíos me habían inculcado" (113). ${ }^{21}$ Se suma a ello su afición por la escritura, de hecho, la oposición de su padre a que se dedique a escribir es lo que genera mayor energía en el deseo de Vargas Llosa por continuar haciéndolo. Él se reconoce como escritor y también reconoce que: "Es probable que sin el desprecio de mi progenitor por la literatura nunca hubiera perseverado yo de manera tan obstinada en lo que era entonces un juego, pero se iría convirtiendo en algo obsesivo y perentorio: una vocación" (113).

Observamos a partir de este momento al Vargas Llosa que es capaz de formar su propia personalidad en ese entorno familiar que le es hostil. Hace de la escritura un medio de vida durante su estancia en el colegio de cadetes de Lima y escribe novelas eróticas y cartas de amor para sus compañeros. Más adelante evoca el momento en que trabajó en el diario La Crónica de Lima. También habla a lo largo de estas memorias sobre su admiración por su tío Lucho, considerado ejemplo de éxito profesional y personal, además de hombre culto.

Hay lecturas que van a influir en su vida definitivamente, tal es el caso del libro de Jan Valtin, La noche quedó atrás, del que dice que "fue para mí un detonante, algo que me hizo pensar por primera vez, con cierto detenimiento, en la justicia, en la acción

\footnotetext{
${ }^{21}$ Desde el inicio de la novela el autor insiste en que era muy inocente en las cuestiones de sexualidad y que hasta que no llega a Lima no sabe ni siquiera sobre cómo se engendran los bebés. Esto hace que la cuestión de la sexualidad no sea algo especialmente reseñable, por lo que en ningún momento vamos a atender a cuestiones íntimas en lo que a esta faceta de su vida se refiere.
} 
política, en la revolución" (207). Esta obra es uno de sus referentes en la toma de conciencia sobre la falta de idoneidad de los regímenes totalitarios. ${ }^{22}$

Otro momento importante que luego se verá reflejado en su obra narrativa es cuando conoce a Julia: "Comenzó un emocionante período de citas clandestinas, a distintas horas del día, en cafecitos del centro o cines de barrio, donde hablábamos en susurros o permanecíamos largo rato en silencio, con las manos enlazadas y la permanente ansiedad de que apareciera de pronto alguien de la familia" (358). Este asunto generó revuelo en la familia por la gran diferencia de edad entre ambos miembros de la pareja. Para él, fuera de la atracción, fue también una forma de reafirmar su posición ante su padre que no sólo condenó el noviazgo, sino que llegó a amenazar de muerte a su hijo si llegaba a casarse con esta mujer.

En esta relación de momentos clave de la vida de Vargas Llosa nos detendremos en el viaje que hizo a París para recoger el premio concedido en un concurso de cuentos convocado por la revista La revue Française. Lo describe de esta forma: "He hecho muchos viajes en la vida y casi todos los he olvidado, pero recuerdo aquel vuelo de Avianca de dos días con lujo de detalles, así como el pensamiento mágico que no se apartaba de mí: "Voy a conocer París" (504). Fue un acontecimiento que inicia un nuevo momento al que se unirá más adelante la obtención de una beca para hacer investigación en la Universidad Complutense de Madrid. Todo ello acabará dándole la oportunidad de ver Perú desde la distancia y acrecienta su necesidad de salir de país y plantearse el hecho de vivir en Europa.

\footnotetext{
${ }^{22}$ Cuenta la historia de un espía que trabajó para los nazis y también para los comunistas de Stalin. El era del partido comunista alemán y la GESTAPO le mató. Es un libro que le hace tomar conciencia de que los
} totalistarismos se tocan. 
En el caso de los relatos que encontramos a partir del segundo capítulo de El pez en el agua, podremos leer a ese Vargas Llosa maduro que de pronto hace de la política una opción de vida. Toda esta parte de las memorias se dedica a relatar desde el instante en que él toma la decisión de ser candidato y el momento en el que fracasa su intento de ser presidente de Perú. Será en el capítulo dos cuando hable de las palabras que le dijo su pareja en ese momento, Patricia: "Si subes a ese estrado terminarás haciendo política y la literatura se irá al diablo. Y la familia se irá al diablo también. ¿Acaso no sabes lo que es hacer política en este país? (47). Finalmente, esto ocurrió y a raíz de una protesta popular contra la nacionalización de la banca peruana planteada por el presidente en aquel momento, Alan García, Vargas LLosa llegará tras todo un proceso a ser el candidato que pretenda dar la alternativa desde la derecha del país andino al partido de izquierdas APRA (Alianza Popular Revolucionaria Americana). En esta serie de capítulos vamos a conocer al Vargas Llosa olítico, a alguien que nos va a explicar el porqué de su contacto con sectores más conservadores y el porqué de su crítica a las ideologías de inspiración socialista y comunista. Podremos seguir en su obra un relato detallado de su compromiso ideológico y político. Él será una persona que en su madurez acaba posicionándose a favor de planteamientos políticos totalmente distintos a los que tuvo durante su juventud. Este cambio lo explica Austin Kelly:

When Vargas Llosa was a committed socialist, he thought that the kind of intellectual freedom he espoused for a creative writer was consistent with the political ends of the Cuban Revolution; when he realized that the two propositions were not compatible, he turned away from socialism, an began to brand a number of leftist politicians and intellectuals as fanatics. This turn informs his literature, and it also informs his political views in the memoir. (177)

Hay toda una obra ensayística que demuestra este proceso de evolución en su pensamiento durante los años previos a los que se relatan en estas memorias. A lo largo 
de toda esa obra encontramos un rechazo frontal del autor a cualquier régimen que en América Latina intente implantar un sistema de gobierno de inspiración marxista por entender que con ello se priva del bien supremo de la libertad a la ciudadanía. No podemos olvidar que Vargas Llosa dice en El pez en el agua que la literatura para él tenía también una función política:

El poder me inspiró desconfianza, incluso en mi juventud revolucionara. Y siempre me pareció una de las funciones más importantes de mi vocación, la literatura, ser una forma de resistencia al poder, una actividad desde la cual todos los poderes podían ser permanentemente cuestionados, ya que la buena literatura muestra las insuficiencias de la vida, la limitación de todo poder para colmar las aspiraciones humanas. (103)

En el caso de Mario Vargas Llosa hay conexiones entre sus vivencias personales y pensamiento político con la trama de gran parte de su narrativa. La tía Julia recoge hechos de la vida real del autor que están en El pez en el agua; La casa verde es un lugar que él mismo conoció y se identifica como el sitio donde iban a tener relaciones sexuales con prostitutas algunas de las personas que vivieron en Piura, lugar de residencia del escritor en su juventud. De igual forma se plantea la inspiración en hechos reales que le hacen dar forma a su novela Conversaciones en la catedral, donde se hace una crítica a la dictadura de Odriá y a la sociedad peruana que se encuentra atrapada en sus usos sociales más corruptos y conservadores. ${ }^{23}$ Sin duda que sobre la parte en la que se relata la vida más personal podemos identificar claramente novelas tan importantes como La ciudad y los perros. En ella son muchas las escenas de violencia, de agresión, de miedo y de ocultación. Muchos de los personajes de todas estas novelas son personas reales con las que el autor tuvo contacto directo. En otros casos, Vargas Llosa, tan sólo toma prestado el nombre para generar personajes de ficción. Con esto queremos decir que abordar el

\footnotetext{
${ }^{23}$ Militar peruano que implantó un régimen militar en el país andino desde 1948 a 1956.
} 
componente autobiográfico en la novela de Vargas Llosa, requeriría tener que hacer una revisión de prácticamente toda su obra de ficción. En sus primeros años como novelista, en muchas de esas obras veremos recogido el ambiente donde él nace, donde se hace adulto, donde decide hacerse escritor ó donde vive del periodismo porque es la forma más fácil de obtener ingresos. Él hace de la escritura un medio para ganarse la vida, algo que él menciona continuamente en las entrevistas que le han hecho y de lo que se siente orgulloso de haber conseguido en su vida. Para él la escritura es su vida, por lo tanto, es imposible desconectar su obra de sus vivencias.

Podemos encontrar rasgos autobiográficos a través de sus personajes y de los lugares donde se desarrollan sus novelas. Esto también ocurre con la obra autobiográfica de Juan Goytisolo. Es inevitable al leer parte de su narrativa no ver al autor español como persona que inspira también muchos de los personajes de ficción. Hay una continua conexión entre lo ocurrido en la vida real y parte de los hechos narrados en la obra de ficción. Tiene mucho sentido, porque en ambos encontramos la convicción de que el autor no se puede desvincular de su realidad personal ni de las circunstancias históricas en las que se produce la escritura de sus obras. Todo ello bebe del concepto sartriano en el que la literatura tiene una finalidad social. Ambos autores van a recoger parte de esta crítica social en su obra narrativa, no solo en su obra ensayística. Bien es cierto que en el caso de Juan Goytisolo podemos decir que su actitud es más beligerante y transgresora desde el momento en que además utiliza como arma de ataque el lenguaje y la gramática. Vargas Llosa, sin embargo, mantiene unos usos más ajustados a las normas gramaticales en su lenguaje narrativo, para cuidar la corrección 
estética de la que habla Camus. Este filósofo y escritor francés tiene una gran influencia en este autor.

Para ambos, la escritura es un proceso de catarsis en la medida que les ayuda a liberar parte de sus fantasmas personales, pero en el caso de Juan Goytisolo, además de esta catarsis, encontramos una forma de compartir una vivencia personal que puede ayudar a personas de su misma orientación sexual a identificar un proceso por el que quizá, también han pasado sus lectores. Ambos autores acaban generando alrededor de este trabajo de escritura un perfil de lectores que se identifican con ellos, con sus vivencias, con sus ideologías y visión del mundo y la actualidad. Cada uno en su medida hace que quienes les leen se vean reflejados en sus obras: unos a nivel psicológico y personal, otros a nivel político e ideológico. Sin duda que, para conocer mejor a los dos escritores, su obra autobiográfica nos ayudará a arrojar luz sobre el porqué de sus proyectos narrativos y ensayísticos. Estos textos autobiográficos recogen los fundamentos de sus ideologías y también nos ayudarán a interpretar las derivas de pensamiento sobre política y también sobre cuestiones como la igualdad, la libertad y la orientación sexual.

Esta lectura también nos permite observar la actitud de ambos sobre los conceptos de nación y masculinidad. Goytisolo rompe con un modelo de país y también con una forma de masculinidad hegemónica. Ya lo hace a partir de su trilogía autobiográfica. Sin embargo, Vargas Llosa, no establece una ruptura frontal, sino que se limita a hablar de hechos, describir situaciones y espacios. Muestra cómo es la vida en una sociedad burguesa a la que él pertenece, pero no la rechaza abiertamente. No cuestiona abiertamente el modelo de masculinidad aceptado por la mayoría de esta sociedad capitalista. Sin embargo, su propia experiencia personal, le va a servir para mostrar las 
consecuencias que tiene en una persona el hecho de que se pueda desviar de lo esperado. La reacción de su padre marca claramente cómo vive él su educación como hombre.

A pesar de sus grandes diferencias, veremos que también hay grandes similitudes, sobre todo en lo que se refiere a la intención de la obra y el objetivo que pretenden alcanzar a través de la escritura autobiográfica. Cuando leemos esta parte autobiográfica y de memorias entenderemos mucho mejor la creación de ficción ya que muchas de las historias que se recogen en sus novelas, tienen su origen en hechos que han ocurrido en la vida real de ambos. 


\section{CAPÍTULO III}

La masculinidad y la nación en la obra de Vargas Llosa y Juan Goytisolo. (Comunidades imaginarias para la conformación y también la crítica del estado-nación)

En este tercer capítulo se aborda la cuestión de la nación y su relación con la masculinidad: Reivindicación del conde don Julián y La ciudad y los perros. Para este análisis tomaremos como base teórica el trabajo desarrollado por Benedict Anderson en Imagined Communities. Anderson hace un exhaustivo trabajo sobre todas las cuestiones que, desde su punto de vista, ayudan a explicar la idea de lo que es una nación. Al afirmar que las naciones son "artefactos culturales" nos hace pensar en el papel que puede jugar en esa formación de la idea de nación una parte de la cultura como es en este caso, la literatura. Anderson nos habla de la importancia de dos sistemas culturales en la conformación de la nación: la religión y la herencia dinástica como pilares de esa comunidad imaginaria:

For present purposes, the two relevant cultural systems are the religious community and the dynastic realm. For both of these, in there heydays were taken-for-granted frames of reference very much as a nationality is today. It is essential to consider what gave these cultural systems their self-evident plausibility, and at the same time to underline certain key elements in their decomposition. (12)

Señalar la religión y también la cuestión del linaje, son asuntos clave en este análisis, más que la cuestión de la herencia dinástica. Ambas cuestiones forman parte esencial de la trama en parte de las obras de ambos autores. Es el caso de La guerra del fin del mundo o La fiesta del chivo en el caso de Vargas Llosa y en Reivindicación, Carajicomedia o Juan sin tierra, de Goytisolo. La cultura europea, y por supuesto, especialmente la cultura de España y latinoamericana tienen como eje central estos dos elementos y, por tanto, todo ello también aparecerá de forma explícita en los textos de las dos novelas objeto de estudio en este capítulo. Goytisolo hace una clara alusión a ese 
sistema religioso que, según su punto de vista, tiene consecuencias devastadoras para la formación de un proyecto de nación plural y diversa que él defiende a lo largo de sus ensayos y también en su narrativa. En el caso de Vargas Llosa, aunque con menor beligerancia, la cuestión religiosa subyace también en parte de su obra, aunque en $L a$ ciudad y los perros resalta la importancia de la ascendencia familiar que sería desde un punto de vista contemporáneo, las clases sociales.

La sociedad peruana es una sociedad clasista y el colegio Leoncio Prado es uno de los instrumentos que tiene el aparato político administrativo del estado para estandarizar los comportamientos de hombres que proceden de diferentes clases sociales con la finalidad de que su formación sea homogénea y en sintonía con esa idea de masculinidad que hará de la nación peruana un ejemplo de los valores más apreciados por el patriarcado. El ejército, según se lee en este texto de Vargas Llosa, ha de ser un espacio donde las individualidades desaparecen para dar lugar a la preparación y formación de un espíritu nacional común que sea compartido y, ante todo, aceptado por la sociedad que dará su visto bueno a los valores y comportamientos que esta institución tiene. Es tan delicado este asunto que cualquier crítica velada a la institución del ejército es recibida con beligerancia. De hecho, La ciudad y los perros fue objeto de esas críticas y ataques violentos por parte de la sociedad peruana. Penny Lernoux, dice que se quemaron en público más de 1000 copias en el colegio Leoncio Prado.

En el trabajo de Anderson se señala al lenguaje como otras de las claves para entender de qué forma se utiliza éste en la formación, difusión y desarrollo de los proyectos de nación; de hecho, se menciona que el lenguaje escrito es uno de los canales esenciales utilizados por la comunidad para aglutinar a las personas que forman 
parte del proyecto del estado. Los medios escritos en cualquiera de sus formas, serán los instrumentos para conseguir esa identificación personal de cada uno de los miembros de esa comunidad nacional. Benedict Anderson lo explica así: "This splendidly engEuropean conception of nation-ness as linked to a private-property language had wide influence in nineteenth-century Europe and, more narrowly, on subsequent theorizing about the nature of nationalism" (68). Es durante el periodo mencionado en esta cita cuando las ideas de la Ilustración toman fuerza en Europa y las nuevas clases sociales burguesas hacen de ellas su arma para romper con las monarquías absolutas que controlan los distintos territorios europeos; de igual forma estas ideas nuevas sirven de inspiración a las clases criollas en los países de la actual América Latina. La clase criolla, considerados españoles de "segunda" por parte de la metrópoli, son los que en su mayoría encuentran inspiración y refugio para sus nuevas ideas sobre lo que debe ser la forma de organización política y en su gran mayoría se harán garantes y promotores de estos nuevos fundamentos ideológicos en los territorios de la actual América latina.

El lenguaje escrito utilizado fundamentalmente en las publicaciones periodísticas será un arma efectiva en este proceso de promulgación de las ideas burguesas y los valores de la independencia. A través de la prensa se difundirán los nuevos conceptos sobre la nación que se inspiran en principios fundamentales como la libertad y la no dependencia de la metrópoli. Todo ello hará que se ponga en marcha un profundo proceso de cambio que dará lugar a los movimientos por la independencia de estas colonias de la corona española. ${ }^{24}$.

\footnotetext{
${ }^{24}$ A todo ello se suma la creación de poderes representativos mediante Asambleas nacionales de representantes de la ciudadanía de esos territorios. Hay casos tan significativos como el artículo del Acta de Independencia de Centroamérica que recoge el derecho a voto por parte de la población procedente de África. Es cierto que el tono en cada una de las actas que se firman en los distintos países tendrán ciertas
} 
Es, por tanto, no sólo el lenguaje, sino en particular, el lenguaje en periódicos y textos escritos, lo que hace posible que se difunda esa nueva forma de organización de la nación; será así, un instrumento indispensable en este momento de grandes cambios en las estructuras de poder del continente americano. Aun así, existirá un control férreo por parte de la metrópoli sobre sus colonias. ${ }^{25}$ No obstante, la aparición de los periódicos nacionales en estas colonias será lo que haga que esta dinámica cambie. De ahí la importancia de este medio de comunicación para la difusión de los nuevos valores. Como señala Susan Kirkpatrick es un elemento de cohesión, que sirve de referente a la hora de difundir las ideas de la nueva burguesía que surge con fuerza en el siglo XVIII en la península y que en el XIX tendrán su reflejo en Latinoamérica, con los criollos, que se identifican con los valores del liberalismo surgido tras la revolución francesa: "This incipient bourgeoisie, increasingly liberal and militant since the beginning of the nineteenth century, not only had its Constitution, elaborated in Cadiz in 1812, but also had its press, a legacy of the enlightened minority of the eighteenth century" (30). La prensa es el medio más eficaz para llegar a un mayor número de personas y ante todo un medio que permitía también las lecturas en grupo, de forma que se convierte en una herramienta eficaz para la difusión de las nuevas ideologías liberales. Todo esto sirve de ejemplo para entender la idea que Benedict Anderson afirma en su trabajo.

diferencias, pero, en definitiva, la mayor parte de ellas, recogen un nuevo modelo de organización social y política, la de estado-nación. Por supuesto, es poca la población que sabe leer en el siglo XIX, aunque no importa tanto el número como el hecho de que esos pocos son quienes pertenecen a las nuevas clases sociales liberales y burguesas que ansían la toma del poder político que hasta ahora les había sido negado. "The pattern is plain in the Americas. For example of the 170 viceroys in Spanish America prior to 1813, only 4 were creoles"(Anderson, 56).

${ }^{25}$ Como señala Benedict Anderson: "Print itself spread early to New Spain, but for two centuries it remained under the tight control of crown and church. Till the end of the seventeenth century, presses existed only in Mexico City and Lima, ant their output was almost exclusively ecclesiastical" (61). 
La literatura, por tanto, se transforma en un medio con poder para difundir el conocimiento de esa nueva realidad social. La prensa también es determinante en la conformación de los nuevos estados-nación. Seguirá siendo así a lo largo del tiempo, incluso en el siglo XX, ambos medios nos permiten analizar, entender y obtener modelos que nos muestren las características que conforman una nación. En este capítulo analizamos textos del siglo XX. Además, Goytisolo y Vargas Llosa utilizan la prensa como medio para difundir sus ideas políticas y análisis de la realidad social en la que se encuentran. Sigue por tanto este poder de influencia de los medios escritos para ayudar a comprender las características y también las críticas que se hacen a la idea de nación.

Esta es una cuestión importante en el desarrollo de la narrativa de ambos escritores, especialmente en el caso del Goytisolo que hace del uso de la lengua un arma de ataque y también de crítica. Puede que el hecho de haber tenido que exiliarse por motivos políticos hiciera que su forma de expresión fuera más beligerante, cuestión que como señala Sophia McClene, es habitual en autores exiliados: "Furthermore, writers in the exile typically are forced to leave their countries precisely because of their relationship to, and use of, language. Consequently they see language as both a source of power and a source of pain" (40). En el caso de Vargas Llosa no es tan acentuada esta rebeldía a través del lenguaje; no obstante, a pesar de no estar exiliado en el momento de escribir La ciudad y los perros, sí que la escritura será el medio que utilizará para hacer una crítica a la sociedad peruana en la que él vivió durante su juventud. De hecho, tanto él, como otros autores de la generación del boom romperán 
precisamente con una forma de lenguaje romántico que caracterizó a las novelas latinoamericanas durante dos siglos, tal y como menciona Penny Lernoux.

La forma en la que se utiliza el lenguaje a la hora de describir personajes y la forma en que interactúan en estas novelas, nos permitirá establecer una relación directa con la representación del género en una nación. Nosotros nos vamos a centrar en la representación de la masculinidad que hacen los autores en sus obras. En cuanto a la relación entre lenguaje y masculinidad Victor Seidler Jeleniewski señala: "We have to explore ways in which dominant masculinities can begin to recognize themselves within their own experience. We have to be ready to question a dominant masculinity's relationship to language and we have to recognize language as an important source of male power" (12). Son muchos los pasajes de las novelas objeto de este análisis en los que el uso del lenguaje es un aspecto fundamental de sus contenidos. A través del lenguaje de los narradores y del lenguaje utilizado por los personajes que aparecen en las novelas que analizamos aquí, podremos ver cómo se lleva a cabo una clasificación de quienes son dignos de alabanza o quienes son marginados en la sociedad a la que pertenecen y que se describe en los textos. Quienes son reconocidos socialmente recibirán palabras de apoyo y enaltecimiento, mientras que quienes son rechazados recibirán de forma implacable, insultos. Existen códigos lingüísticos que ayudan a establecer relaciones de camaradería que reforzarán esa idea de masculinidad hegemónica que hemos mencionado a lo largo de esta tesis. De ahí que la forma de expresarse a través del lenguaje tiene el poder de expresar ideas y también ayuda a establecer una clasificación de quienes son considerados hombres aceptables para la sociedad y quiénes no. La escritura es una tecnología que ayuda a presentar 
subjetividades como señala Paul B. Preciado. Quien lee lo que otra persona escribe, está percibiendo una realidad desde el punto de vista de quien la ha escrito. El poder de la escritura está en revelar un punto de vista que en algunos casos puede ser contrario a los intereses de un estado. Por eso, los libros y la prensa, en algunos estados nación son elementos que hay que controlar. Ese control pretende hacer que esa tecnología de la escritura de la que nos habla Paul B. Preciado, no ponga en peligro sus principios básicos.

Muchos de los personajes que aparecen en las novelas más allá de mostrar su individualidad, representarán modelos que ayudan a identificar a la nación como entidad comunitaria. Personajes como el Jaguar de la novela de Vargas Llosa representa al hombre que usa sin límite la violencia para poder ser aceptado por la comunidad del Leoncio Prado. Todo lo contrario ocurrirá con el Esclavo que es ninguneado, insultado, marginado y señalado por el grupo de cadetes que están en el colegio militar ya que su forma de comportamiento no se corresponde con lo que se espera de un chico que será militar y luchará por la patria. Le gusta escribir y se siente fuera de ese ambiente hostil que representa esta academia militar. Se deja llevar por emociones y formas de comportamiento que no son aceptadas como propias de esa masculinidad del ejército. Alguien que no cumple con lo esperado por la institución puede ser marginado y de esa forma, se rompería el prestigio que adquiere la familia al tener miembros en esta academia militar. Esa pérdida de reconocimiento social podría provocar problemas en la familia y por tanto, se pone en peligro la continuidad de la fama y apoyo social al apellido que uno representa. La nación necesita de sus cachorros que reproduzcan sus intereses para garantizar su pervivencia. En el fondo de esta idea, subyace la cuestión de 
la importancia que tiene el linaje, un concepto que se remonta al tiempo de los caballeros medievales y que se transforma a lo largo de la historia. Leo Braudy nos ofrece claves para entender como el estado asume este asunto como algo propio de la masculinidad que lo define:

The social rituals of violence that had taken up so much of medieval masculine life were therefore to be focused instead on violence in the name of the state. At the same time, the actions of the man of violence, whose personal inclination as well as class compulsion was to fight, would be justified no only by a chivalric code but also by a nascent sense of national identity. (133)

Este tipo de personajes que también pueden identificarse en las novelas de Vargas Llosa o Juan Goytisolo, están hechos a semejanza de los caballeros medievales que nos comentaba Braudy. El Jaguar, o los militares de rango del colegio Leoncio Prado, sirven de base para establecer los principios que definan el modelo de masculinidad hegemónico. En el caso de la obra de Goytisolo, este tipo de hombres son objeto de crítica explícita en Reivindicación y con ella, manifiesta su total rechazo porque cree que su enaltecimiento genera un gran daño para que aparezcan otros modelos de masculinidad que representen un estado más diverso y rico culturalmente. Juan Goytisolo ha tenido como referencia en su idea de nación española la mezcla de culturas, la diversidad de religiones y las distintas formas de ser personas. La diversidad será el elemento que defina el modelo de nación para el autor barcelonés. En las novelas de Vargas Llosa también aparecen personajes que perfectamente podrían ser ejemplo o modelos que se pueden identificar con las distintas clases sociales que forman la sociedad peruana del momento, ofrece también ese punto de vista en el que se muestran diversos modelos. Alberto y el Esclavo provienen de la clase media limeña, mientras que el Jaguar pertenece la clase obrera. Es curioso que este último sea un 
personaje muy violento; de alguna forma ha de conseguir su validación por parte de la comunidad haciendo valer su fuerza para poder sobrevivir; si no lo hace, tiene mucho que perder. En el caso de Alberto, personaje que tiene la habilidad y la sensibilidad de saber escribir, sobrevive porque hace de ello su negocio y evita la crítica por ser sensible al ayudar a los demás a conquistar a las mujeres que desean. Se transforma en un instrumento para esa comunidad. El Esclavo, Ricardo Arana, es quien se lleva la peor parte. Su relación con la escritura es íntima y nada tiene que ver con la cuestión mercantil. Al final, a pesar de venir de la clase acomodada, acaba desapareciendo porque no encuentra su lugar en esa estructura de poder que representa la escuela limeña de cadetes. Todos estos personajes conforman un mapa humano que nos permite conocer las estrategias que siguen las personas para poder encajar en un modelo de nación en el que se les considera miembros con la responsabilidad de hacer pervivir los principios de un sistema patriarcal basado en la reproducción como elemento definitorio del mismo. Quienes no se ajusten a esa expectativa, acabarán recibiendo un castigo por disidencia.

En el caso de Reivindicación del conde con Julián, tendremos un claro ejemplo de esa disidencia, de esa crítica a un modelo de nación que, según el autor, ha provocado un gran daño en la historia de España. Es una obra que establece una ruptura entre el autor de Barcelona y esa España del caballero cristiano y la unidad de lengua, raza y religión; esa España de la pureza de sangre y la honra como elementos de estratificación de clases sociales que acoge con fuerza el régimen de Franco a partir de que el General ganara la guerra y tomara el control del país tras su golpe de estado contra la II República. En un pasaje de esta obra dice así: "Y abriéndote paso entre la 
manigua, inaugurarás caminos y atajos, inventarás senderos y trochas, en abrupta ruptura con la oficial sintaxis y su secuela de dogmas y entredichos" (222). Con estas palabras expresa ese narrador proteico el momento de ruptura que podemos relacionarlo con la vida personal del propio autor. ${ }^{26}$ Goytisolo expresa su deseo manifiesto de comienzo de un tiempo nuevo que le ofrezca nuevos campos para la exploración no sólo literaria, sino también para su vida personal, y es que la segunda novela de la trilogía Mendiola, es una pieza más en este estilo de escritura que marcará un antes y un después en la producción literaria de este autor.

Goytisolo llega a abandonar su país de nacimiento tras la gran presión a la que es sometido por el régimen franquista. Vive un exilio que le hace alejarse de esa nación opresora y vivirá en palabras de Angel Gasquet, la muerte civil y la muerte física:

Otra gran diferencia entre estos dos tipos de viaje reside en que en el viaje forzado la ecuación pérdida-ganancia ya no existe; todo contabiliza como pérdida. El viajero forzado lo pierde todo: una existencia completa, sus certezas, sus seguridades, la unión y cohesión con sus pares, la identidad, etc. La partida del viaje forzado está en un punto más próximo a la muerte física que a la muerte civil. (46)

Bien es cierto que Goytisolo elige voluntariamente la marcha de su país de origen, pero no es menos cierto que se sintió presionado por el acoso al que fue sometido por parte de la maquinaria de propaganda que el régimen de Franco puso en marcha contra todos los que estaban en contra de sus preceptos, ideologías y doctrinas. En Reivindicación mata simbólicamente a la nación española, al mismo tiempo que se establecen las bases del nacimiento de un nuevo mundo, un nuevo espacio y una nueva cultura que ayudarán a Goytisolo a definir un nuevo momento vital y literario; un mundo en el que construye

\footnotetext{
${ }^{26}$ Carmen Sotomayor en su libro Una lectura orientalista de Juan Goytisolo nos habla del narrador proteico. Se trata de una figura narrativa que se transforma a lo largo del texto adoptando a veces la forma de narrador, o la voz del propio autor.
} 
desde su visión de Oriente, desde su visión de la cultura árabe, un imaginario que dé sentido a sus futuras obras y a su propia vida. Analizamos aquí cómo se produce esa muerte simbólica, esa pérdida del vínculo con la madre patria y cómo se teje una idea de otro modelo de nación deseada con la que Goytisolo se siente cómodo a nivel personal y como escritor. Se identifica con este nuevo mundo, entre otras razones, porque le ofrece la posibilidad de vivir su homosexualidad de forma abierta. Plantea por tanto una nueva posibilidad de dar lugar a una nueva nación y por tanto, también a un nuevo modelo de masculinidad. A través de este proceso, es clave su conexión y entusiasmo con el Sur, un sur geográfico y cultural por el que se siente atraído desde sus primeras visitas a Almería donde se encontró un ambiente absolutamente distinto al que le ofrecía su Barcelona natal. Un sur que se extiende hasta el norte de Marruecos y más concretamente a Tánger, una ciudad que tradicionalmente ha acogido a numerosos autores y artistas del siglo XIX y XX como nos comenta Joseph A Boone en su artículo "Vacation Cruises".

A través de su obra se recoge un viaje en lo personal, y por otro lado, un análisis de su visión sobre la España que ha dejado atrás. Ejerce una crítica feroz a ese país que le ha excluido y cuando lo hace, se encuentra en un espacio desde el que puede ver la península a lo lejos. Ese lugar es supuestamente Tánger y allí se encuentra al abrigo del ideario de la cultura árabe que será la que le permita encontrar un nuevo espacio vital y de inspiración artística, además de soporte para la construcción de un nuevo modelo de nación y también de masculinidad. Para él, la conexión de España con la cultura árabe es determinante. Al-Andalus será una gran fuente de inspiración continua 
para él. De ahí que el sur de la península sea un lugar clave en su vida y también en su obra.

En Señas de identidad, primera de novela de la trilogía, hay una búsqueda de todos aquellos elementos que identifican el contexto en el que vivió desde su infancia hasta su juventud. Escribe sobre esas señas de identidad que le ayudan a explicarse a sí mismo y la influencia que ejercieron sobre él las personas con las que pasó ese período de su vida, así como el contexto histórico, político y cultural de ese momento en España en el que se vivió el estallido de la Guerra Civil y la implantación de un régimen totalitario fascista. Se trata de una necesidad de saber de dónde se viene para poder explicar el porqué de ese deseo de romper, de escapar, de desvincularse del lugar al que se ha pertenecido por nacimiento. Con su segunda novela procede a materializar a través de la escritura esa muerte física, con el expreso deseo de iniciar un nuevo momento que le permita ser él mismo. Se trata de una muerte con esperanza, la esperanza de inaugurar un tiempo nuevo: "Augurio de una vida mejor y más libre, lejos de la funesta península y de su aletargada fauna: con aguda y enigmática sencillez: sedativa diana que inaugura el nuevo día, compensación y antídoto del brutal despertar: apostado en el chaflán como de costumbre, fuera de tu campo de observación”. (Reivindicación 90) En estas palabras observamos esa visión esperanzadora de lo bueno que vendrá. A lo largo de la obra vamos a encontrar mezclados dos tonos de ánimo a la hora de hablar de su país de origen: un tono de esperanza por ese ejercicio catártico que para él tiene la escritura de esta novela y a la vez un tono de reproche y crítica feroz hacia un modelo de país que cree perdido para siempre por su sinrazón hacia quienes piensan de forma distinta a los principios oficiales de una España unida, sin cabida para la diversidad en cualquiera de 
sus expresiones. Precisamente ese sentimiento es el que conduce al autor a la necesidad de atacar a todo aquello que ha provocado que España haya llegado a un punto de la historia en que tras el enfrentamiento de la Guerra Civil, se encuentre con que la persona que provocó la sublevación contra la II República sea ahora el dictador que implantará un régimen totalitario que eliminará, perseguirá y encarcelará a todos aquellos que no estén bajo su mismo posicionamiento ideológico. Es precisamente el reproche a la intolerancia ejercida contra todo aquel que se mostró crítico contra el régimen lo que genera sus palabras más críticas e incisivas en ese deseo de dejar en evidencia los defectos de la "madrastra". ${ }^{27}$ Todo ello hace que Goytisolo se posicione claramente en contra de todos los elementos históricos y culturales que han alimentado ese pensamiento intolerante y que ha tenido siempre como consecuencia la exclusión de todo aquel que no se ajusta a un modelo caracterizado por la unidad de comportamiento, de pensamiento, de religión y de visión moral de la sexualidad. El autor necesita eliminar ese universo cultural, ese imaginario social, esa España del caballero cristiano que desde su punto de vista ha causado tanto daño a lo largo de su historia y que toma de nuevo fuerza con la dictadura franquista, por ser defensora a ultranza de esa visión miope de una nación.

¿Cómo procede a la ejecución de su "madrastra"? Lo hace desde varios frentes y uno de ellos es con el uso que hace del lenguaje al entender que éste es uno de los elementos esenciales que han ayudado a formar ese imaginario totalitario de una España unida, donde la diversidad no ha tenido cabida. Las palabras en esta novela son utilizadas como arma de destrucción. Lo hace con un estilo que muestra una continua vulneración y ataque de las normas básicas de puntuación. Se trata así de expresar de forma desafiante su disconformidad con cualquier normativa, también la ortográfica, que

\footnotetext{
${ }^{27}$ Término que también utiliza Luis Cernuda en parte de su obra para referirse a España como madre patria.
} 
obligue a seguir unas reglas sin posibilidad de que sean aceptadas nuevas propuestas. Los tratados de gramática son vistos por Goytisolo como una forma de controlar y excluir a quienes no cumplan con sus preceptos. No podemos olvidar cómo en el siglo XIX, momento de surgimiento de todos los nuevos estados-nación en muchos lugares del mundo, tiene lugar en el ámbito de la cultura hispana, la publicación de gramáticas que tienen como objetivo principal, controlar el lenguaje de los países de habla hispana y unificar las normas gramaticales para garantizar la pureza de la lengua. Goytisolo reacciona también contra estos dogmas utilizando como técnica narrativa un uso desordenado de las palabras de forma que sumerge al lector en un laberinto que tiene como consecuencia que éste tenga que volver continuamente hacia atrás en la lectura para encontrar sentido al texto. Otra de las técnicas para provocar esa sensación es el cambio de código al pasar de un idioma a otro como señala Ellen Mayock: "The autor also breaks through linguistic borders by surprising the reader at every turn with his constantly creative, innovative use of the Spanish language and by using as well phrases in Arabic, French, and English"(11). No acepta que se imponga la existencia de una sola lengua cuando la historia de la península ha demostrado que siempre ha sido uno de los territorios con mayor número de lenguas de Europa. También reflexiona sobre la arbitrariedad del género cuando nos habla de "caperucito rojo", rompiendo así toda una tradición narrativa y de género en su afán de mostrar la vulnerabilidad y debilidad de una realidad que se ha mostrado hasta ese momento como absoluta y que el autor demuestra mediante la escritura de esta novela, que no es así.

Reivindica la riqueza que ofrece la mezcla de culturas, la consecuencia de esa hibridez surgida de la convivencia entre tradiciones y formas de lenguaje que se dan en 
los abundantes territorios donde llegó el español tras la conquista del continente americano. Lo hace evidente en una parte del texto cuando escribe con los giros propios de otros dialectos del español de Latinoamérica. Lo hace con sarcasmo y con una clara intención de subrayar el hecho de que el mestizaje produce riqueza y no es necesario eliminar nuevas formas surgidas por esa mezcla con personas de otros territorios en los que existían otras lenguas, otros vocabularios y que al llegar esta lengua desde la península e imponerse durante más de tres siglos, tiene como consecuencia, entre otras cosas, una diversidad de expresiones y vocabulario que hubiera sido impensable si ese encuentro entre culturas no se hubiera producido. Al incorporar estas formas diversas de dialectos del español, Goytisolo da valor a las mismas al incorporarlas a su obra narrativa y cede un espacio para que estas formas distintas de utilizar el español tengan cabida. Además, para ser aún más provocador, menciona a uno de los padres de la literatura nacional española en ese texto híbrido cuando dice: "boy boy pinche gachupín quiobas con totacho abusadísimo mi cuás ya chingaste hace ratón con tu lopevega ora te chinas gachupas ora te desflemo el cuaresmeño". (261) Se trata de un desafío en toda regla a las normas básicas de un concepto único de léxico y de gramática, que trata de unificar, clasificar y sobre todo, marcar la clase social en función de la adecuación del lenguaje a los preceptos establecidos. La colonización de un territorio no implica una reproducción exacta de la cultura del colonizador, sino que, como dice Homi Bhabha, en Location of Culture, da lugar a una mímesis, a una nueva forma que nunca es exactamente igual a la de la metrópoli que ejerció su poder colonizador, sino que tiene su aspecto y forma de desarrollo propio en base a esas características físicas, geográficas, culturales y ambientales del lugar donde se produce. Pretender que tan sólo exista una forma correcta 
de hablar español es cerrar el reconocimiento al valor que puede adquirir una lengua al hablarse por millones de personas de distintos territorios y continentes y que, además, viven realidades muy distintas a las del país que los colonizó.

También hay un ataque directo a las obras canónicas de la literatura española. Estos listados de obras tienen como finalidad la selección de textos que garanticen la pervivencia de una idea de nación con la que el aparato del estado esté de acuerdo. Como señala Jo Labanyi en "Relocating Difference: Cultural History and Modernity in Late Nineteenth-Century Spain", la finalidad de este canon es el de clasificar qué autores merecen ser leídos y cuáles quedarían excluidos. Goytisolo se mofa de ese canon defendido desde el régimen franquista; lo hace al hablar del Siglo de Oro español cuando dice: "nostalgia fugaz que te arrebata al bello siglo de Cartón Dorado y a tu país de mierda" (120), o cuando se refiere a la generación del 98 con su admiración por un único paisaje posible, el de Castilla, la tierra que marcó los destinos gloriosos de la expansión del Imperio Español. El hecho de criticar obras literarias que sitúan la mayor parte de los relatos en la región castellana cobra más sentido cuando leemos lo que Jo Labanyi dice al respecto de estos textos de la periferia:

It is thus important that a large number of novelists, including most of those incorporated into the national canon, should have located many or all of their novels in the provinces rather than the capital. For one of the functions of the late nineteenth-century "national novel" is to bind the nation together by encouraging readers from anywhere in the national territory-provided they are Castilianspeakers-to empathize with the issues and anxieties of characters located in the whole of the Peninsula. (171-72)

Por lo tanto, la intencionalidad de Goytisolo en su ataque a la Generación del 98 tiene como objetivo ir contra otro de los pilares que definen a esa España que él ataca, como nación. Utiliza un humor mordaz al hablar de este período literario: "Entre los lentos 
paisajes del Noventa y Ocho: graves, monacales, adustos: por la llanura inacabable donde verdea el trigo y amarillea el rastrojo: centrando tu interés en una araña de dimensiones medias" (113). Al leer sus palabras parecería que habla de un conjunto de novelas vacías, que no tienen sentido, que no aportan nada nuevo, que tan sólo cuentan historias carentes de contenido y que se centran en temas intranscendentes, novelas pesimistas, sin color. También lo hace con autores de otras épocas. De hecho en ese ataque se hace mención a 55 autores, como apunta Gonzalo Sobejano ${ }^{28}$. Con unos muestra confrontación directa, con otros, como es el caso de Góngora, hace del uso de sus versos y la mención de parte de su obra un eje conductor que inspira su escritura a lo largo de toda la novela. El autor cordobés es siempre una inspiración para escritores que quieren romper con esa idea de nación unitaria y homogeneizadora que inspiró momentos oscuros de la historia de España.

Como hemos visto hasta ahora encontramos un ejercicio continuo de violencia contra el país de origen del escritor, pero esta violencia no es sólo practicada contra algo externo, también la ejerce contra sí mismo. Es lógico que lo haga porque, como dijimos anteriormente, el modelo de nación también se identificará con un modelo de masculinidad determinado. De ahí que el autor español al criticar la patria, también critique y haga una reflexión de su experiencia como hombre nacido en esa construcción cultural e ideológica de una España con la que no se identifica. Goytisolo relata un acto de sumisión y a la vez de perversión sexual que tiene especial relevancia en la obra. Se trata de un acto de pederastia donde un niño, que es el Álvaro de Señas de identidad, se

\footnotetext{
${ }^{28}$ En el artículo de Gonzalo Sobejano se hace una investigación por las distintas citas que Goytisolo incorpora en Reinvindicación del conde don Julián y clasifica en tres grupos a los 55 autores que se encuentra citados dentro de la novela: el sector positivo entre los que se encuentran Américo Castro o Cervantes, el sector negativo entre los que se encuentran Antonio Machado, Manuel Machado o Menéndez Pelayo; y el sector neutral entre los que se encuentra Alfonso X el Sabio, Espinel o Espronceda.
} 
ve entre atacado y "seducido" por alguien de quien en principio tiene miedo pero a quien finalmente acaba aceptando y entregándose. En ese fragmento asistimos al enfrentamiento de los miedos infantiles y en particular al temor que siente al enfrentarse a algo que socialmente se considera monstruoso e inadmisible: la homosexualidad. Hablamos del fragmento en el que se cuenta como un abuelo abusa cada noche de su nieto, sin que éste lo denuncie. Finalmente, el personaje acaba aceptando sin resistencia ese abuso sexual, aunque no deja de manifestar esa sensación de angustia y ese sentimiento de culpa que le invade ante tal hecho. Es también en este pasaje donde se puede decir que se produce el suicidio simbólico de Álvaro y el nacimiento de otra persona distinta al reconocer abiertamente su nueva orientación sexual. Goytisolo lo hace como si se tratara de un cuento en el que el lobo se acerca "hacia el niño paralizado, mudo, que no quiere ni puede apartar de ti la vista en tanto que la belicosa sierpe se insurge y tu sangre, al sentirlo cerca, brinca y brinca hacia él sin poder contenerse" (285). ${ }^{29}$ Ese monstruo tiene varios nombres; en principio se llama Bulián que es alguien que surge de un mundo nuevo al que hasta ahora Álvaro no pertenecía. Este personaje le dice “soy Bulían, tu admirador y amigo: pobrecito guardián de infaustas, avarientas obras: el abismo social que nos separa me impedía declararte mi pasión” (285). Ese abismo social que menciona puede interpretarse como la distancia que existe entre la cultura y el mundo al que pertenecía Goytisolo en su infancia (España) y el mundo al que pertenece tras su exilio (el mundo árabe). Ha tenido que llegar este momento de ruptura, de desvinculación con su pasado y con su país para que pueda estar en disposición de afrontar no sólo esa ruptura con su lugar de origen sino también con su pasado heterosexual y el encuentro

\footnotetext{
${ }^{29} \mathrm{El}$ cuento tiene la función pedagógica de mostrar el mundo de los adultos en una forma que sea asequible a un público infantil. Muchos de los personajes de los cuentos tienen una función simbólica.
} 
consciente con su nueva orientación sexual. Un reconocimiento no ausente del sentimiento de culpa cuando dice:

"Postrándose de hinojos ante el sagrario y repitiendo entre lágrimas el Yo Pecador: pero todo es inútil y lo sabéis los dos: llegada la hora a su regreso del colegio, los pasos le encaminarán inexorablemente hacia la calle desierta en donde el prudente celador de las obras aguarda" (286).

A pesar de ese sentimiento de rechazo, sigue existiendo una poderosa atracción por quien le atrapó entre sus brazos, por esa homosexualidad que se identifica con violencia pero que no por ello deja de serle atractiva. Goytisolo muestra esa lucha entre el cargo de conciencia por lo que se cree que está mal hecho y el deseo profundo de hacerlo: "la enfermedad, la miseria, el tormento le invaden: un fuego destructor convertirá un limpio y gallardo corazón del niño en un endurecido trozo de lava: su cuerpo se cubrirá de pústulas, sentirá en los huesos un dolor vivísimo" (291). Es una lucha entre el sufrimiento y la atracción; es un proceso de transformación que acaba con el suicidio imaginario de ese niño que hasta ese momento se sentía culpable por sentir deseo por alguien de su mismo sexo. El responsable de esa muerte es Julián, el traidor, y todo lo que representa como personaje perteneciente al mundo árabe con el que se siente tan identificado el autor de la novela. En ese acto de suicidio se produce a la vez el nacimiento de un nuevo ser que afronta cara a cara una nueva realidad. Lo describe así:

balanceándote: y así como en la mente del que agoniza desfila entera la vida en unos cortos instantes, así su primitivo candor fugitivamente aparece; delgado y frágil: vastos ojos, piel blanca: el bozo no asombra aún, ni profana la mórbida calidad de las mejillas; y tal halcón al acecho, apuras la brevedad del milagro, abrazándote a él: serpiente troglodita, flagelador hircino, en simbiosis fulmínea: 
impugnando la muerte que os cierne: monstruo no, ni bifronte, ni $\mathrm{Jano}^{30}$ : tú mismo al fin, único, en el fondo de tu animalidad herida. (294-95)

Ese "tú mismo al fin" muestra el alivio que produce el enfrentarse cara a cara a algo que hasta el momento había causado angustia y desazón. Es un momento de esperanza porque como decía al inicio de este capítulo, no todo es destrucción en esta obra. Se trata precisamente de un texto que hace de la destrucción el paso previo necesario para generar un espacio alternativo, un nuevo mundo en el que el escritor se sentirá no sólo cómodo, sino que además hará de él el lugar para su inspiración intelectual y también el lugar para ambientar sus historias futuras. ${ }^{31}$ Ese nuevo espacio se caracteriza por la visión de Oriente que tiene Goytisolo. Se puede apreciar a través de sus palabras cómo el autor se siente atraído por su filosofía, su arquitectura, su forma de vida y sus principios. Es precisamente esta visión de lo árabe la que sirve de contrapunto constante a lo largo del texto y, como señala Sotomayor, sobre este nuevo mundo: "este aparece como contraposición al mundo occidental que el autor quiere criticar" (100). Es simbólico que el personaje protagonista sea el conde don Julián que es conocido según la leyenda -se duda de que fuera un personaje real- como el responsable de la invasión musulmana de la Península. Se trata de un visigodo que ante la pérdida de poder se alía con los musulmanes y les facilita el acceso a la península por Gibraltar para luego tomar en un plazo corto de dos años prácticamente todo el territorio peninsular. El propio Goytisolo habla sobre su intencionalidad en la elección de este personaje como protagonista de su novela:

\footnotetext{
30 Jano es el dios romano de los "buenos principios" representado por dos caras, una joven y otra vieja, colocadas de tal manera que podrían mirar en dos direcciones a la vez.

${ }^{31}$ Se entiende que la escritura de esta trilogía marca un punto de inflexión en la creación literaria de Goytisolo. A partir de ésta aparece una nueva forma de escribir.
} 
Count Julian is not (as title might suggest) a historical novel within the connotation in which the term is generally used. The narrator is an anonymous being who contemplates the Spanish coast from Tangiers and identifies himself with Count Julian, the visigothic governor of the area, the Great Traitor who, as legend has it, opened the portals of the Peninsula to the Muslims. (Count Julian 112)

Goytisolo comparte una idea en la que Occidente siempre ha interpretado a Oriente desde su visión colonizadora bajo una mirada de superioridad cultural y política. En este punto coincide el autor de Reivindicación con Edward Said, autor de Orientalism. ${ }^{32}$ Es tal el vínculo entre ambos que Said llega a decir sobre Juan Goytisolo en la edición española de su libro:

Desde 1978, y debido en gran parte a mi creciente familiaridad con la obra de Américo Castro y Juan Goytisolo, he llegado a darme cuenta no solo de cuanto hubiera deseado saber más acerca del orientalismo español mientras escribí mi libro durante los años setenta, sino hasta qué punto España es una notable excepción en el contexto del modelo general europeo cuyas líneas generales se describen en Orientalismo. (Orientalismo 9)

El elogio entre ambos autores es mutuo y si bien el escritor español es defensor y admirador de la obra de Said, no se puede olvidar que quien ejerce una influencia determinante en Goytisolo a la hora de interpretar la cultura oriental, será Américo Castro. Cuando Sotomayor define la visión sobre Oriente de Goytisolo, la nombra como "Oriente castrista": "Los juicios del historiador condicionan además su percepción de la cultura española en contraposición a la árabe" (74). De hecho, como señala la misma autora, Reivindicación del conde don Julián es "su contribución a la tarea emprendida por Castro" (75) y sigue diciendo: “Tanto para Castro como para Goytisolo, las secuelas del conflicto siguen afectando al devenir histórico de la España del siglo XX. Las 'voces oficiales’ del régimen franquista perpetúan la visión imperialista y católica a ultranza de una España que el narrador de Reivindicación del conde don Julián quisiera eliminar con una nueva invasión sarracena de la península" (77). Castro y Goytisolo coinciden en la

\footnotetext{
${ }^{32}$ El propio Goytisolo escribió la presentación para la edición en español de esta obra.
} 
crítica sobre el mito que explica la ancestral esencia histórica española; también critican ambos el análisis que se hace del pasado de España, la visión de grandeza que inicia el relato de los orígenes prehistóricos de la Península en las Cuevas de Altamira y que siempre ha restado importancia a la influencia ejercida por la cultura semita. De lo que no cabe duda es que el Oriente que habita Goytisolo se fundamenta en una visión personal que tiene sus propias características. El autor no puede dejar de mostrar la extraordinaria influencia que ejerció en la Península la presencia de los musulmanes durante tantos siglos y lo que ello implicó para las ciencias, las letras, el arte, la gastronomía, la lengua y las costumbres sociales de aquella época. ${ }^{33}$ Esto es fundamental para entender la visión alternativa de nación que subyace en su obra y por qué hace del estudio de las culturas condenadas a la expulsión de la Península por los cristianos, su principal objeto de estudio y en muchos casos, tema redundante en su obra ensayística y narrativa.

Goytisolo rechaza los valores absolutos y eso es lo que no le gusta de esa España cristiana que tiene la religión como guía y que niega lo que dejaron de influencia a lo largo de su historia las aportaciones a la cultura de la Península otras religiones y culturas. ${ }^{34}$ Hay un jesuita del siglo XVIII que fue muy importante a la hora de valorar la

\footnotetext{
${ }^{33}$ Roberto Dainotto hace una reflexión sobre los países del sur de Europa en los que hubo influencia de la cultura musulmana (Italia, Portugal y por supuesto España) y lo que ello implicó en el desarrollo de la historia y cómo ha afectado a la relación con otros países del continente europeo a los que los musulmanes no pudieron llegar. Realiza un estudio sobre estos países del sur al hablar de Europa y qué papel juega la historia en la percepción de las naciones. En su libro Europe in Theory habla de algunas cuestiones que pueden perfectamente entrelazarse con la visión de Goytisolo sobre su idea de Oriente. En ese trabajo se plantea el concepto de historicismo que queda definido de la siguiente forma: "Historicism had emerged as the conviction that every civilization and every period has its own possibilities of aesthetic perfection; that the works of art of the different peoples and periods, as well as their general forms of life, must be understood as products of variable individual conditions, and have to be judged each by its own development, not by absolute rules of beauty and ugliness". (107)

${ }^{34}$ Ese interés en negar parte de la historia es algo que coincide también con la Europa del norte. Daniotto hace un magnífico estudio sobre cómo se origina el eurocentrismo a partir de las ideas de Montesquieu en contraposición a esa visión más abierta y tolerante de Voltaire. La intencionalidad del primero es la de magnificar la importancia de la aportación francesa al origen de la Europa moderna situando a Francia como el epicentro donde surge la civilización occidental. Será precisamente Juan Andrés, un jesuita
} 
aportación que hicieron otras culturas y religiones a Europa y más concretamente, a la Península. Su nombre es Juan Andrés y apuesta por la importancia de las Belles Letres ${ }^{35}$ como elemento en el que ha de basarse el estudio de la realidad. También tiene una visión novedosa en ese tiempo sobre lo que para él es el historicismo: "Andrés's historicism, instead, was based on the assumption that no place and no time was the ultimate end of history” (115). Es precisamente la investigación que él llevó a cabo durante su estancia en Italia la que le lleva a la conclusión de que el origen de la Europa moderna está precisamente en lo árabe. El jesuita español sitúa como origen de la poética de la Europa moderna la influencia que ejercieron los textos árabes, cuestión que choca frontalmente con esa visión euro centrista que tradicionalmente ha considerado lo Oriental como irrelevante para la historia de Europa y que ha tenido como consecuencia la consideración de España y del resto de países europeos en los que hubo presencia musulmana, como países de segundo nivel. ${ }^{36}$ Goytisolo y Juan Andrés coinciden en esa visión que tienen sobre la importancia de lo árabe y el papel que jugó no sólo en la definición de la historia de una parte de Europa, la del sur, sino en el resto del continente, al situar precisamente en esa influencia musulmana, el origen de la poética occidental y como consecuencia el origen de la civilización occidental. Pretender que haya una separación abrupta entre un momento histórico y otro como si nada estuviera relacionado tiene como consecuencia una visión sesgada de la historia. Coinciden también en que

español del siglo XVIII que tuvo que exiliarse a Italia por resultar incómodo su forma de pensamiento en la Península, el que rompa con esa teoría eurocentrista.

${ }^{35}$ La idea de que la palabra era necesaria como instrumento para expresarse en cualquiera de las disciplinas del conocimiento, incluidas por supuesto las ciencias. Una visión en la que cualquier texto puede tener importancia por sí mismo, lo importante es el poder contextualizarlo históricamente y apreciar el valor que tiene en ese momento.

${ }^{36}$ Italia también se encuentra en este grupo por la importante presencia musulmana en Sicilia. 
ambos se tuvieron que exiliar y sus trabajos más importantes son producidos fuera de España. Goytisolo sería como uno de esos escritores románticos que hacen de la hibridez un valor y construye una realidad nueva con sus propios rasgos de identidad. Esos valores conforman su idea de nación y su deseo de acercarse a los territorios donde la cultura musulmana sigue en pleno vigor. Parece desprenderse de este análisis que quienes ejercen una crítica a un modelo de nación excluyente en temas de diversidad, tan sólo lo pueden hacer desde fuera del territorio geográfico que ocupa esa patria.

Siguiendo en la búsqueda de elementos que ayuden a identificar el concepto particular que Goytisolo tiene sobre lo oriental, cabe mencionar el trabajo que hace Susan Martín-Márquez con su análisis sobre el colonialismo africano español. La autora analiza en su trabajo ese proceso de generación de la idea de la nación de España a lo largo de la historia y el papel que ha jugado lo árabe en esa construcción. Señala dos momentos en ese proceso de crear una identidad: el que llama primera oleada que se identifica con la España que defiende la pureza de sangre ${ }^{37}$ y que tiene como consecuencia la expulsión de los judíos y de los musulmanes. Le sigue otro período que ella denomina la segunda oleada que coincide con la España ilustrada y liberal y que se distingue por resaltar la aportación de la cultura árabe en la forja de esa idea de nación. Esta segunda oleada surge en el XVIII y se mantiene hasta finales del XIX. Es un momento en el que España tiene especial interés en enaltecer lo árabe porque se piensa que con ello se jugará un papel determinante en ese deseo de conquistar territorios del norte de África, ya que Europa está pensando en ese momento histórico en poner en marcha un nuevo proyecto colonizador de expansión hacia ese continente. Es tal el interés por lo árabe que surgen

\footnotetext{
${ }^{37}$ La autora señala cómo se produce una vision organicista de la nación al decir: "Study is grounded in the conviction that from very early on in Spain, "biology" frequently underpins the imagination of national identities, albeit in ever-shifting, historically contingent ways (203).
} 
arabistas que se dedican al estudio en profundidad de todo ese legado. Estos se dividen en dos corrientes opuestas: los que presentan este pasado como algo que provocó un efecto positivo (Fernández y González) que se traduce en su influencia en las letras, las artes, las ciencias y la cultura; y otros que lo presentan como un momento en el que la historia de España estuvo sujeta a un tiempo de barbarie y destrucción (Simonet). Esta última comenta cómo en un momento se produce el auge del segundo punto de vista que servirá de argumento para quienes creen que hay que colonizar el norte de África con la idea de volver a culturizar a quienes fueron expulsados en 1492 y huyeron a estos territorios, ya que tras todo ese tiempo han perdido la esencia que les distinguió durante el periodo andalusí en la Península. Hay un uso perverso de la interpretación de la historia con fines puramente económicos e interesados en el que hay una parte de la población que demoniza a los árabes que estuvieron en el territorio peninsular y justifica su expulsión para más adelante cambiar su punto de vista y justificar la colonización del norte de África con la idea de salvarles de la ignorancia a la que se han visto sometidos tras irse del continente europeo. Como dice Aurora Morcillo: "Spanish Orientalism is utilized by both traditional and progressive intelelectuals" (263). Los unos intentan resaltar la diversidad cultural que fue consecuencia de esa convivencia entre las tres religiones (judía, cristiana y musulmana) en el mismo territorio y otros, intentan mostrar a España como un país civilizado que tiene que ejercer su dominio colonial para atajar la situación de desvarío y salvajismo de todos aquellos territorios que no se gobiernan bajo los principios del catolicismo. Goytisolo se identifica sin duda con esa primera corriente de arabistas que realzan la aportación de la cultura árabe en la historia de España y cómo su influencia no sólo marca el destino de un país, sino el de todo un continente y una 
civilización. Sin duda que Goytisolo participaría de la visión del arabista Fernández y González que se dedicó a escribir sobre la importancia de Al-Ándalus y la influencia de su legado cultural y cómo este período marcó una gran diferencia con el resto de los territorios europeos que no tuvieron presencia musulmana. Su idea de nación tiene que ver con esa diversidad, con el entender que el resultado de la idea de España se forma como consecuencia de un mestizaje, de una interacción entre culturas y religiones. Es una forma de ver la nación totalmente distinta a la mostrada por esa España franquista en la que hay valores absolutos y se excluye todo lo que se identifique con el único modelo de nación que bebe de la religión católica.

En esa idea del orientalismo que alberga su modelo de nación, habrá un aspecto que forme parte de ese imaginario que el escritor barcelonés defiende. Hay un modelo de masculinidad que pasaría a tener cabida dentro de ese modelo de nación. Goytisolo se asemeja aquí a un grupo de escritores que ven en ese Oriente la existencia de lugares donde el placer y la sensualidad son algo que forma parte de su esencia. El deseo por el otro es algo que, en el caso de los homosexuales, sobre todo en el siglo XIX, se identificará con los habitantes de Oriente Medio. De este asunto nos habla Joseph Boone: "For such men, the geopolitical realities of the Arabic Orient become a psychic screen on which to project fantasies of illicit sexuality and unbridled excess" (89). No sólo ha sido un sueño de los homosexuales, sino también de hombres hereterosexuales que como señala Boone en el mismo artículo:

Many heterosexually identified men have traveled to the Arabic Orient in pursuit of erotic fulfillment as well, but even these adventurers have had to confront the specter of male-male sex that lurks in their fantasies of a decadent and lawless East; such encounters put into crisis assumptions about male sexual desire, masculinity, and heterosexuality that are specific to Western culture. (90) 
Es un mito inventado por los occidentales, ya que si indagamos en los preceptos religiosos musulmanes sobre la homosexualidad encontraremos que esta orientación sexual es castigada desde el punto de vista religioso, como señala Louis Cromptom : "It is a decree that both the active and passive partners should be stoned, a tradition which have a definitive influence on Islamic law" (143), e incluso habla de escuelas teológicas musulmanas que llegan a pedir la aplicación de la pena de muerte para quienes tienen relaciones con personas del mismo sexo. Dicho esto, el mismo autor hace un estudio sobre la presencia de relatos en los que se mencionaban historias entre parejas del mismo sexo en la obra de poetas y escritores de Al-Ándalus. Entre estos escritores destaca el poeta Ibn Hazm, del cual es admirador Goytisolo. Este autor andalusí escribió El collar de la paloma, un tratado en el que se recogen diferentes historias de amor: "Yet Ibn Hazam repeteadly intermingles stories of men falling in love with other males" (Crompton 146). El mismo poeta confesaba que intentaba evitar asistir a fiestas y lugares donde pudiera sentir la tentación de relacionarse con otro hombre porque lo consideraba pecaminoso, pero a la vez reconocía que tenía que luchar contra la atracción que sentía por personas de su mismo sexo. Este autor andalusí sacó a la luz muchas historias de amor entre personas de gran la renombre de la sociedad andalusí entre las que se encontraban personajes importantes de la política del momento: el emir de Sevilla Al Mutamid o el califa Abd al-Rahman III. Se alimenta así la idea romántica de permisividad ante este comportamiento sexual que ha formado siempre parte de ese Oriente imaginado por parte de muchos autores occidentales. Quizá Goytisolo entiende la homosexualidad en el mundo árabe desde esta perspectiva y es por ello que demanda una idea de nación que incorpore todo ese pasado que tuvo que ver con la cultura musulmana 
porque es la forma de hacer posible la existencia de masculinidades alternativas, que en el caso del ideario católico, eran imposibles de incorporar y reconocer. En muchas de las obras de Goytisolo encontraremos esa búsqueda de conexiones entre las distintas culturas que han habitado en la península a lo largo de su historia y la razón es la necesidad de demostrar que podría haber otra idea de país que sería mucho más inclusiva y en la que la diversidad de modelos podría tener cabida sin que se establezcan venganzas o persecuciones. Tiene su lógica, ya que el autor, como hombre homosexual, se sentiría mucho mejor en esa comunidad diversa que en la que Franco implantó por orden dictatorial.

Ahora vamos a hacer este mismo acercamiento a la cuestión de la nación y la masculinidad en la obra de Vargas Llosa y lo vamos a hacer a través de su primera novela. Un trabajo que aborda de forma directa la influencia de la institución militar en la conformación de ese ideal masculino y cuya misión será la de conseguir formar a los hombres en los valores que garanticen la pervivencia del modelo hegemónico. En $L a$ ciudad y los perros podemos encontrar un retrato de la sociedad peruana de los años 50, tal como dice Vargas Llosa en una entrevista que le hicieron en México con motivo del estreno de la adaptación teatral de la novela. En sus páginas podemos observar como hay grupos sociales dentro de esa sociedad que saltan ese muro de lo permitido públicamente y basan su supervivencia en mantener una actitud de confrontación con las normas del entorno. En la novela de Vargas Llosa hay un ejemplo claro de lo que significa esta actitud de lucha y cómo se ejerce una tarea de control de estas conductas que pueden generar disonancias con el modelo de masculinidad hegemónico. Uno de los ejemplos de este tipo de comportamiento es el que se lleva a cabo en la novela por el llamado Círculo, 
un grupo de jóvenes que da lugar a liderazgos alternativos y conductas que ponen a prueba la rigidez de una institución militar de prestigio nacional en Perú, el Colegio Leoncio Prado. Partiremos del análisis de la experiencia vital del autor de la novela como base para entender la influencia que ejerce dicha experiencia sobre lo que escribe; de ahí iremos al análisis sobre qué elementos del texto nos ayudan a la construcción social del modelo de masculinidad y en último lugar revisaremos qué tipos de estructuras de control se dan para que el modelo de masculinidad esté garantizado y qué consecuencia tiene esa disciplina severa, ese control de la norma y el uso del castigo como elemento corrector para quienes la transgreden, algo que es habitual en instituciones de este tipo.

En la novela aparecen nombres, lugares, hechos que pasan de la realidad a la ficción literaria, en algunos casos como espejo de lo que Vargas Llosa vivió en su vida personal, y en otros, con elementos que desdibujan, cambian o modifican historias vividas por el autor en su vida real. José María Oviedo nos da a conocer datos sobre la biografía del escritor. Oviedo es un experto en la obra del Premio Nobel como crítico literario, pero, además, tiene un vínculo personal con él, ya que fueron compañeros de colegio en La Salle de Lima cuando eran niños. Nos ofrece claves que ayudan a entender la realidad y crudeza de algunas de las vivencias de Vargas Llosa. Sobre la estancia en el Colegio Leoncio Prado, Oviedo señala: “Los años que allí pasó Vargas Llosa, constituyen su primera experiencia fundamental, el descubrimiento del dolor, de la violencia, del compañerismo del mal; en una palabra, de la vida". (22) En la novela son muchas las escenas de violencia, de agresión, de miedo y de ocultación. Muchos de los personajes que aparecen en La ciudad y los perros están basados en personas que existieron en la realidad y con las que el autor tuvo contacto directo; en otros casos tan sólo toma 
prestado el nombre que tenían en la vida real y construye un personaje de ficción en su novela. El padre de Alberto, el personaje principal de la novela es el alter ego del padre de Vargas Llosa, tal y como hemos comentado en el capítulo dos. Si hay alguien que aparece con fuerza en ella y que tiene una conexión directa con el autor en la vida real, es este personaje que en la vida real fue también quien decidió el ingreso en el Colegio Leoncio Prado y Vargas Llosa lo explica así:

Su idea era la de muchos papás de clase media con hijos díscolos, rebeldes, inhibidos o sospechosos de mariconería: que un colegio militar, con instructores que eran oficiales de carrera, haría de ellos hombrecitos disciplinados, corajudos, respetuosos de la autoridad y con los huevos bien puestos. (El pez en el agua 113)

En esas palabras traducimos el concepto de masculinidad que tiene su padre. Vargas Llosa era continuamente castigado y agredido físicamente por su progenitor al entender que su afición por la lectura y la escritura no encajaba con el modelo de "hombre de verdad” que esperaba de él. Como señala Robert Richmon Ellis:

In the narration of childhood and adolescence, Vargas Llosa charts the mechanisms through which masculinity is fashioned and men are made. Like many traditional Peruvian and Latin American writers, he equates the facticity of maleness with masculinity, and in turn posits masculinity as synonymous with male heterosexuality. (224)

Al final, Vargas Llosa será alguien que acabe actuando conforme a lo esperado por parte de su padre. Es cierto que la escritura y la lectura son sus pasiones, pero la forma en la que va a acabar enmascarando ese gusto considerado poco masculino, será haciendo de él su forma de vida, la forma en la que va a poder conseguir subsistir. La escritura es motivo de castigo por parte de su padre por ese temor a que su hijo tuviera un comportamiento desviado. Cualquier acercamiento al mundo de las emociones, de los sentimientos, de la ternura o de la sensibilidad artística eran considerados como femeninos y por tanto, rechazados y tratados para que se cambiara de actitud. Es tan importante esta vivencia 
personal que de ella surgen dos personajes protagonistas en La ciudad y los perros. Es como si se produjera un desdoblamiento de la personalidad de un ser real a dos personajes en la ficción. Tenemos por un lado a Alberto Fernández, el Poeta, que tiene gusto por la lectura, pertenece a una familia de clase media peruana y hace de la escritura una vía de escape personal y un modo de supervivencia en el Colegio Leoncio Prado ya que cobra dinero de sus compañeros a cambio de escribir cartas de amor o historias eróticas para las mujeres a las que quieren conquistar. Utiliza de esta forma su talento literario para sobrevivir en un mundo hostil, en un mundo en el que la violencia y la ausencia de sensibilidad son valores apreciados y premiados con la aceptación del grupo. La escritura es para él una forma de evasión; escribe en un rincón oculto del colegio, donde nadie lo ve, pero eso si, lo hace con la esperanza de conseguir a cambio dinero, cigarrillos o favores que le permiten planear sus salidas: "Mientras, Alberto planea la salida del sábado. Podría que unos diez tipos se soñaran con la película esa, y viendo tantas mujeres en calzones, tantas piernas, tantas barrigas, tantas, me encarguen novelitas, pero acaso pagan adelantado......Podría que me pidan cartas pero quién se fía de un negro" (23). Esta persona se salva del acoso porque está siendo utilizado como recurso para que los compañeros puedan tener relaciones con mujeres que quedan seducidas por las palabras de alguien que no son ellos, pero que les permite conseguir a alguien deseado.

El segundo personaje que representa ese desdoblamiento de la experiencia personal de Vargas Llosa es Ricardo Arana, el Esclavo. En la novela, este personaje tiene una relación traumática con un padre, que aparece en su vida tras mucho tiempo sin saber nada de él. Además de aparecer tarde, le castiga, le agrede físicamente en público y 
continuamente le dice que tiene que hacer de él un "hombre de verdad". Su padre culpa a la madre y a la familia de ésta por la educación que ha recibido Ricardo en su ausencia y encuentra en el colegio Leoncio Prado el lugar idóneo para que se corrija la forma de ser de su hijo, que hasta ese momento estaba totalmente apegado a su madre. El Esclavo se siente traicionado por ella al no encontrar su apoyo cuando denuncia el trato abusivo de su progenitor. La madre intenta convencer a su hijo de que ese maltrato físico que recibe de su padre busca en el fondo conseguir lo mejor para él.

A diferencia de Alberto, Ricardo Arana no consigue que las burlas recibidas por parte de sus compañeros no le afecten. Se siente impotente ante este tipo de agresión verbal. Lo único que le alivia es su relación con Alberto, alguien que comparte gustos similares con él. Su percepción de sí mismo es muy negativa y sus recuerdos de infancia hacen que se reafirme en su actitud de víctima: "No era la primera vez, en el Colegio Salesiano le decían "muñeca". Era tímido y todo lo asustaba. "Llora, llora, muñeca', gritaban sus compañeros en el recreo, rodeándolo. El retrocedía hasta que su espalda encontraba la pared" (153). Su mayor error fue el de hacer evidente ante los demás su debilidad: "Ahora ya no tenía esperanza, nunca sería como el Jaguar, que se imponía por la violencia, ni siquiera como Alberto, que podía desdoblarse y disimular para que los otros no hicieran de él una víctima. A él lo conocían de inmediato, tal como era, sin defensas, débil, un esclavo" (154). Esta desesperación le lleva a utilizar la traición como herramienta para conseguir la posibilidad de salir de lo que se había convertido en su trampa, el colegio Leoncio Prado. Ricardo es una persona diferente en una institución que pretende homogeneizar comportamientos para producir el modelo de hombres que la sociedad patriarcal demanda. El objetivo Ricardo Arana, sería claro, si no se transforma 
habrá que eliminarlo. En realidad, es imposible no tener diversas formas de comportamiento conviviendo en un espacio colectivo como este colegio militar. Como dice R. W. Connell: "It has become increasingly clear that different masculinities are produced in the same cultural or institutional setting" (36). En este caso, Ricardo es alguien que traspasa unos límites y transgrede los principios que definen a ese modelo hegemónico de hombre. Por ello, será una víctima y como resultado, desaparecerá. Su actitud asociada con un comportamiento que es entendido como femenino, desencadena la ira de los demás y provoca que se sienta desplazado, marginado y también maltratado, tal y como le ocurría en casa con su padre. A diferencia de lo que Alberto hacía con sus escritos, Ricardo no ofrecía nada al grupo, no había un interés económico y no había un intercambio con el resto de compañeros, así que cuando da lugar a la traición delatando hechos que ocurrían en el colegio a los mandos superiores, nunca se le perdonó. Es más, que desapareciera no cambiaría en nada lo que estaba ocurriendo entre el grupo de cadetes. Como señala Connell: "We must also recognize the relations between the different kinds of masculinity: relations of alliance, dominance and subordination. These relationships are constructed through practices that exclude and include, that intimidate, exploit, and so on" (37). En el caso de Ricardo las relaciones están basadas en la subordinación y provocan su marginación y también la ira del grupo por considerarlo un traidor y alguien que no aporta nada que beneficie al grupo.

Ese proceso de censura, de insulto, de enaltecimiento o de camaradería que se da en el Colegio Leoncio Prado nos ayuda a conocer cómo se produce la construcción de lo masculino en una institución de este tipo. A lo largo de la lectura de La ciudad y los perros encontramos distintas actitudes, omisiones, silencios y acciones 
que nos ayudan a percibir cómo se construye un modelo de hombre, un modelo de masculinidad que pretende ser el único posible y que, para su defensa, genera mecanismos de rechazo contra todo aquel que intente actuar de forma contraria a los principios sobre los que se genera. En ese proceso de construcción podemos apreciar tres elementos importantes: la actitud de las madres de dos de los personajes principales de la novela; el tipo de lenguaje que se utiliza por parte de los perros y cadetes del Leoncio Prado y, por último, viendo los comportamientos y comentarios homófobos que están presentes de forma constante en algunos de los personajes de la obra.

Hay un componente social y psicológico en ese proceso de construcción de lo masculino. Nancy Chodorow nos habla sobre el modelo de maternidad. Se centra en el papel de la mujer como cuidadora con carácter exclusivo, cuestión básica para garantizar la supervivencia de la hegemonía de un modelo en el que como también señala la autora americana, las mujeres transmiten a sus hijas su educación para ser buenas madres, cuidadoras; mientras que de igual forma, en el caso de los hijos, se reprime su capacidad de preocuparse por el cuidado de sus hijos ya que esto sería función exclusiva de la madre (mujer). En la novela, las madres de Alberto y Ricardo se han dedicado a la crianza de sus hijos, pero no tienen capacidad de decisión en todo aquello que implique pensar en el futuro de sus hijos cuando sean adultos. En ambos casos, son los maridos quienes plantean, sin importarles lo que opinen ellas, cuál es el camino a seguir. En este caso lo que imponen es que sus hijos vayan a formarse como hombres al colegio de cadetes Leoncio Prado. Es más, la figura del padre maltratador está presente en esta novela. La madre de Ricardo recibe palizas del padre porque éste considera que ella ha maleducado y consentido a su hijo al haberle permitido hacer cosas que no son propias de 
los hombres, según el criterio de su padre: "Lo has educado mal", decía él; "tú tienes la culpa de que sea así. Parece una mujer" (95). Este maltrato se hace extensivo también al hijo que recibe palizas de su padre. Ante esta violencia, la madre pide a su hijo que tenga comprensión hacia el padre; ella misma asume que el hombre es violento por naturaleza y que merece la pena aguantar este maltrato porque el objetivo es hacer del hijo un hombre de provecho. Insiste en la bondad de esa violencia, incluso lo empuja a la humillación ante el agresor:

“Anoche me pegó”, dijo él, roncamente. Un puñete, como si yo fuera grande. No quiero vivir con él. Su madre seguía pasándole la mano por la cabeza, pero ese roce ya no era una caricia, sino una presión intolerable. "Tiene mal genio, pero en el fondo es bueno", decía la madre. "Hay que saber llevarlo. Tú también tienes algo de culpa, no haces nada por conquistarlo. Está muy resentido contigo....Ahora que vuelva, pídele perdón por haber entrado al cuarto. (136)

La madre acepta también que esa violencia es necesaria para poder educar correctamente al hijo. Esta actitud de justificación de lo que ocurre por parte de la mujer está generando también un modelo de entender la masculinidad asociado al comportamiento agresivo.

La doble moral es otra de las cuestiones que surgen del texto del autor peruano, el personaje de la madre de Alberto refleja falta de capacidad para luchar contra la infidelidad de su marido. Ella se encuentra atrapada en su matrimonio y no toma ninguna decisión al respecto. En ese modelo hegemónico masculino, el hecho de la promiscuidad es valorado positivamente si es el hombre el que la lleva a cabo ya que se considera que tener sexo es una necesidad masculina y nunca femenina. En muchos casos, la infidelidad en los hombres, es valorada como símbolo de virilidad y de éxito. De hecho, los amigos de Alberto comentan sobre las aventuras con otras personas que tiene su padre y lo tratan con admiración por ello. Se construye así ese enaltecimiento de la figura del hombre conquistador de mujeres como ejemplo de la actitud del modelo de masculinidad 
heterosexual. Como señalan Tim Carrigan, Bob Connell y John Lee: "the institutionalization of heterosexuality, as in the family, was achieved only by considerable effort and at considerable cost not only to homosexual people but also to women and children" (109). La madre del Poeta, aunque emocionalmente dolida, no tiene la posibilidad de rebelarse y decide mantener la relación para no generar comentarios en el vecindario o en la propia familia. Hay una actitud de inmovilismo, de resignación. Se dibuja de nuevo una forma de reaccionar desde lo femenino hacia ese poder avasallador de lo masculino. El texto de Vargas Llosa nos muestra así el rol que se espera de las mujeres en ese modelo de masculinidad y también en ese modelo de nación que relega a las mujeres al papel exclusivo de cuidadoras.

Otro de los elementos sobre los que podemos medir la percepción del modelo hegemónico masculino se basa en el rechazo hacia todo lo femenino. El sistema binario para establecer diferencias entre masculino/femenino, heterosexual/homosexual, provoca que el modelo masculino que ostenta el poder se defina en función del contraste con su opuesto. Ese rechazo explícito de todo lo que pueda significar que un hombre tenga una conducta asociada con lo femenino provoca que sea ridiculizado e insultando en ese entorno de masculinidad hegemónica; se dan comportamientos homófobos. Esta homofobia, como señala Eric Anderson, ha sido un elemento fundamental para la producción de una masculinidad ortodoxa; por ejemplo, los adolescentes reciben mensajes para que repriman cualquier actitud o forma de comportamiento con sus iguales que pueda identificarse como propia de una mujer. Es también un arma arrojadiza contra los jóvenes. En el caso de La ciudad y los perros, Ricardo Arana es el más castigado con este tipo de actitudes por parte de sus compañeros y también por su propio padre. Hay un 
discurso generalizado en la sociedad, que excluye a todo aquello que pueda identificarse con lo femenino: actitudes que demuestren debilidad física o ausencia de agresividad. Ricardo recibe continuamente este tipo de mensajes; por la mañana, en su casa, escucha: "Fuera de la cama, entonces - dijo la voz - Sólo las mujeres se pasan el día echadas, porque son ociosas y tienen derecho a serlo, para eso son mujeres. Te han criado como a una mujerzuela. Pero yo te haré un hombre". (194) De igual forma, Alberto y el Esclavo reciben bromas que intentan ridiculizarles hablando sobre su posible homosexualidad, ya que siempre están juntos. Es inconcebible una relación entre hombres fuera del componente de la dominación o la violencia. Ese odio a lo femenino, ese rechazo continuo a lo que representan socialmente las mujeres provoca desigualdad no solo en ellas, sino también en todos aquellos hombres que no cumplan con el modelo del vencedor. Como señala Anderson, el discurso misógino genera desigualdad entre hombres y mujeres, y, además, reproduce la homofobia y ese rechazo entre hombres.

El uso de determinado tipo de lenguaje es otro elemento que nos permite distinguir rasgos de ese modelo masculino hegemónico. Incorporar a la oralidad palabras malsonantes, usar habitualmente el insulto compulsivo, en este caso con carácter claramente sexista y homófobo con palabras como marica, mujerzuela, maricón, mujercita, muñeca, hace que se visibilice el rechazo hacia todo aquél que no cumple con los rasgos que la sociedad patriarcal espera del hombre. Hay una continua elocución de términos y palabras que tienen como misión avisar de qué se espera de ese hombre de verdad: "Es usted muy macho"; (La ciudad 198) "leonciopadrinos de pelo en pecho y bolas de toro". (91) Es otra señal de masculinidad el tener conversaciones explícitas entre los cadetes sobre sexo, por supuesto, siempre que se hable de relaciones sexuales con 
mujeres. También será habitual entre ellos el uso de palabras malsonantes como formas habituales de expresión para demostrar su hombría. El lenguaje adquiere así un tono más violento. En un estudio basado en la grabación de diferentes conversaciones entre hombres, Jennifer Coates señala que los hombres mediante su discurso pretenden mostrarse como ejemplos de esa masculinidad hegemónica, que mantienen la forma que se espera de ellos de ser hombres. De igual forma ocurre en la novela de Mario Vargas Llosa. Hay un uso continuo de las palabras para censurar o enaltecer actitudes. Las palabras dan visibilidad a los pensamientos y a través de ellas se construye también un modelo de género. A lo largo del texto será común leer un lenguaje soez, agresivo; en el caso de que alguien del grupo no hable en esos términos, será objeto de sospecha por parte de los demás. El grupo se controla a sí mismo para que no haya disensiones.

La Ciudad y los perros es una novela en la que aparecen mayoritariamente personajes masculinos y en la que son ellos no sólo los protagonistas, sino los que en todo momento toman la iniciativa en un mundo de hombres. Podemos interpretarlo como un retrato de la sociedad masculina peruana en la que el poder está en torno a un modelo que se fundamenta en el rechazo a todo lo femenino para garantizar su supervivencia: "Hegemonic notions of masculinity demand that to be a 'real man' requires the rejection of all things femenine, in that masculinity is constructed in oposition to feminity". (Altsop 143) Ese poder hegemónico ha de dotarse de estructuras que permitan hacer que prevalezca sin fisuras. En la novela de Vargas Llosa distinguimos dos instituciones básicas: la familia y el Colegio Leoncio Prado. Es en el núcleo familiar donde comienza el proceso de socialización y transmisión del modelo para conseguir que los miembros masculinos de la misma cumplan con los valores que la sociedad espera de ellos en base a 
ese modelo de masculinidad hegemónico. Ricardo Arana (el Esclavo) y Alberto Fernández (el Poeta) proceden de dos familias de distinto origen social; no obstante, ambas confían en el resultado que se obtendrá tras el paso de los hijos varones por el colegio Leoncio Prado. Son además los padres de ambos personajes, los que mantienen una creencia ciega en el poder del internado militar para educar a sus hijos en lo que la sociedad espera de ellos como hombres. Estos dos adolescentes sufren antes de ser enviados al Leoncio Prado el rechazo de sus padres por no tener un comportamiento que se ajusta a lo esperado de ellos como hombres. Son juzgados por hombres (sus padres, en primera instancia y por sus compañeros, más adelante) en todo momento. En esta etapa de adolescencia, la madre es relegada a un papel secundario y sin capacidad de decisión mientras que los hombres son los únicos "autorizados socialmente" para tomar este tipo de decisiones: todo queda entre hombres. Para considerar la adquisición del estatus de hombre es necesario obtener la validación de otros hombres: los padres, los amigos; no cuentan las mujeres, el poder de lo masculino se construye sobre la negación de lo femenino. La familia forma parte de una estructura superior a nivel social y su función es claramente relevante en el contexto de la educación formal, tal como se señalan Connel en un trabajo sobre la importancia de esta institución en el proceso educativo de cualquier persona. De esta forma, podremos conocer cómo es un estudiante conociendo rasgos de la vida familiar que ha tenido. En el caso de Alberto y Ricardo, esta cuestión condiciona cómo será el paso por el colegio. La forma de vivir en esa estructura no puede obviar las experiencias familiares que han tenido antes de llegar a ella.

El Colegio Leoncio Prado asume todo un mandato social como institución educativa. Este espacio es considerado como el lugar idóneo para poder cubrir las 
deficiencias educativas que se han podido cometer en el ámbito de la familia. De hecho, sus responsables definen en la novela la misión del colegio de la siguiente forma: "A la mitad los mandan sus padres para que no sean unos bandoleros - dijo Gamboa -. Y, a la otra mitad, para que no sean maricas" (204). En el caso de Ricardo y de Alberto, son literalmente los padres quienes los envían a estudiar allí, confiando en que ocurra lo segundo que se menciona en la novela. En el caso de esta institución, el principal elemento diferenciador es que pertenece al ejército; se organiza por tanto, bajo la normativa militar y será esta una de las claves para poder interpretar todo lo que allí ocurre con los cadetes.

El ejército hereda a lo largo de la historia el papel que en la Edad Media cumplían los caballeros. Como señala Leo Braudy en el siglo XVII aparecen los primeros ejércitos y será en el siglo XIX, cuando la burguesía, como clase dominante, adopta esos valores de la antigua aristocracia y los toman como propios. Surge el concepto de nación que hace suyos esos valores y los transforma en algo colectivo, para toda la ciudadanía. Se garantiza así ese modelo de masculinidad hegemónico haga de la institución militar una garante de los principios patriarcales que se traspasan a estas nuevas clases sociales. Si hay algo que puede representar los valores de la masculinidad hegemónica es lo militar:

Writers who have developed critiques of masculinity suggest that there is a form of masculine identity (hegemonic masculinity) that boys and men are generally encouraged to aspire to. This form of masculinity is characterized by the interrelationship of stoicism, phallocentricity and the domination of weaker individuals, competitiveness and heroic achievement. Thus, men who exemplify this model of masculinity tend to be accorded a higher social status than those who do not.... Military organizations, military successes, military pageantry, and rituals such as the "passing out" parades for successful recruits to the armed forces represent the public endorsement of such values and their institutionalization in national culture. (Higate 112) 
El Colegio Leoncio Prado cumple esta función de estandarización y control de todo lo que no se ajuste al modelo que la sociedad patriarcal necesita para su supervivencia. Se trata de un lugar en el que la sociedad deposita la tarea de mantener esos valores masculinos hegemónicos y a cambio, quienes pasen por él, obtendrán prestigio social y poder. Esos valores, además, se asocian con el concepto de nación como entidad colectiva. Quienes llegan a este centro son formados bajo un modelo de enseñanza que asegure que no se pondrá en riesgo la estructura de la sociedad para la que trabajan. Sus propios responsables (oficiales) asumen su papel de ejemplo, de modelo a seguir. Es una institución masculina, como nos dice Todd W. Reeser: "Historically speaking, of course, the military has been an all-male institution and serves as a coming-of-age institution for boys, so increasing the connections between the military and the nation can do help render the nation more masculine" (173).

El sistema de monitorización es estricto; los reglamentos, la disciplina y la cadena de mando son la supuesta base para que todo esté controlado. El Colegio Leoncio Prado puede ser un ejemplo que coincide con la estructura del panóptico de la que nos habla Foucault. La torre desde la que se vigila todo acogería a la jerarquía que forma la cadena de mando. Se caracteriza por la total opacidad en su forma de actuar. Nadie puede conocer lo que ocurre allí dentro. Sin embargo, desde esta torre se pueden vigilar todos los movimientos de quienes están en el territorio objeto de su observación, es decir, todo lo que hacen los cadetes del colegio será controlado por los mandos de la academia militar. Para facilitar el control, hay toda una estructura de poder basada en la cadena de mando, que tendrá como misión entre otras cosas, la de informar de lo que está 
ocurriendo entre los sujetos objeto de observación. Ese mecanismo disciplinario es definido por Foucault de la siguiente forma:

This enclosed, segmented space, observed at every point, in which the individuals are inserted in a fixed place, in which the slightest movements are supervised, in which all events are recorded, in which an uninterrupted work of writing links the centre and periphery, in which power is exercised without division, according to a continuous hierarchical figure, in which each individual is constantly located, examined and distributed among the living beings, the sick and the dead - all this constitutes a compact model of the disciplinary mechanism. (197)

En La ciudad y los perros podemos leer cómo su autor nos muestra los movimientos en ambos lados del panóptico. Entre los oficiales que dirigen el colegio (torre) se produce una motín tras el suceso de la muerte de un cadete durante el desarrollo de un ejercicio táctico con fuego real. Este hecho desencadena toda una serie de reacciones en esa cadena de mando que ve peligrar su prestigio y su puesto de oficiales y para conservarlo no dudan en mentir y en eliminar a todas aquellas personas que están en ese mismo nivel de responsabilidad y que no están de acuerdo con esta maniobra de encubrimiento de la verdad. El teniente Gamboa es el ejemplo más claro de este rechazo por parte de otros oficiales, ya que se posiciona a favor de que se esclarezcan los hechos ocurridos y quiere que sean los propios cadetes implicados en la muerte de uno de sus compañeros, los que puedan dar su versión y ayudar a aclarar lo que ocurrió. Hay una frase del comandante del colegio que señala la forma de pensar a la hora de resolver un asunto tan delicado como este: "Recomienden a los cadetes discreción absoluta. Los trapos sucios se lavan en casa" (272). El poder que controla la institución se siente amenazado para poder continuar en esa posición privilegiada al quedar patente que el sistema disciplinario del colegio que pretende controlar cualquier comportamiento que vaya en contra de las reglas, ha hecho aguas. Que haya llegado información sobre lo ocurrido a Ricardo Arana, 
que fue la víctima de un disparo durante un ejercicio táctico, es la punta del iceberg de todo un entramado de conductas que estaban siendo contrarias con el reglamento y que no fueron controladas debidamente por el sistema. Ante ello, deciden callar y disfrazar la realidad. No se puede poner en cuestión que desde la torre (quienes tienen la misión de controlar) no se ha hecho adecuadamente la tarea que tienen encomendada. Este acontecimiento permite comprobar cómo existen estructuras de poder paralelas. En el caso del texto de Vargas Llosa, esa estructura es la que se conoce como el círculo, un grupo de cadetes liderado por el Jaguar y que se dedican a actuar a escondidas de sus jefes directos. Llevan a cabo conductas que van no sólo en contra de las normas del colegio (se roba ropa, se consiguen preguntas de exámenes antes de hacerse, se venden servicios, se amañan salidas fuera de los horarios permitidos, etc.) sino que además, algunas de ellas, pueden sobrepasar lo admisible en el propio modelo de masculinidad hegemónico como es el caso de la existencia de comportamientos homoeróticos (masturbaciones colectivas) o la zoofilia. Vargas Llosa nos muestra a través de los ojos de Alberto y Ricardo todo lo que se hace en ese grupo de cadetes y cómo se desenvuelven ellos con los miembros de éste. A pesar de estar en una institución militar con un control férreo, podemos comprobar la actividad de estos grupos se produce a escondidas de quienes les controlan y es en ese ámbito de lo oculto, donde tienen cabida comportamientos que estarían fuera de lo aceptable. Sobrepasan límites, llegando incluso a haber relaciones sexuales entre algunos de esos cadetes. Es cierto que se sabe que en instituciones en las que no se permite la convivencia entre hombres y mujeres, suele ser común la existencia de relaciones homoeróticas y homosexuales (prisiones, ejército, etc...) Eso sí, lo que ocurre de alternativo, tan sólo puede darse en el ámbito de lo oculto 
para no distorsionar en ningún momento la misión de la institución que en este caso es formar a los hombres de verdad para la nación. En ese grupo, por supuesto no tienen cabida quienes no cumplen con los comportamientos deseados. El esclavo fue eliminado porque no se ajustaba a las expectativas. Quienes lo eliminan son sus propios compañeros, cuestión que hace ver cómo funciona la sociedad disciplinaria de la que nos hablaba Foucault que controla desde la alta cadena de mando, pero también desde las bases.

Tras estos análisis podemos por tanto llegar a una serie de conclusiones. Con respecto a la visión de la nación, encontramos en la obra de Goytisolo la necesidad de ejecutar a la que denominó su madrastra porque él era una de las personas que no se sentía parte de una comunidad donde valores con los que él comulgaba, no eran aceptados por esa nación en la que nació. Todo ello forma parte de un proceso de transformación y sobre todo de evolución en lo ideológico y también a nivel personal. Goytisolo se enfrenta abiertamente al régimen de Franco desde su exilio en el norte de África y lo hace desde ese Oriente con el que se siente identificado. Critica que se haya negado ese pasado de una península donde convivieron tres culturas distintas en una armonía razonable. Hay una tarea expresa de borrar esta etapa por parte de quienes implantaron su ideología y sus principios, los cristianos. Estos y quienes en la historia contemporánea toman los valores de ese momento de la historia de la península (Franco) hacen todo un ejercicio de gestión del olvido. También es cierto que, a partir de ese punto de rechazo hacia sus orígenes, el autor comienza a construir un mundo a su medida, toma elementos que le hacen sentir que pertenece a un nuevo espacio en el que se siente más cómodo. El hecho de que sea en Tánger donde se sitúan los relatos que escribe más 
adelante, tiene todo su sentido ya que el norte de África ha sido un espacio en el que muchos escritores y artistas del XIX y del XX encuentran su forma de vida y el nuevo lugar que inspirará sus obras. Es una ciudad que les permite distanciarse de Europa y a la vez no estar demasiado lejos de ella. En el caso de Goytisolo esta ciudad representa ese lugar físico y cultural que se asemeja al sur de España y por el que tanta admiración siente. Es un lugar donde hay elementos de esa cultura árabe que tanto ha influido en el sur de la Península, donde es imposible abstraerse de esa realidad que estuvo asentada durante ochocientos años. Vivir en el Magreb es una forma de habitar en una idea de España negada por Franco en su interés por magnificar el pasado cristiano. Un sur peninsular dentro de ese oriente cultural que está en el norte de África y en el que se puede vivir con pleno sentido todo lo que para el autor de la novela representa lo oriental. Es una relación con esa cultura que tiene un nivel profundo en lo intelectual y lo personal y no como se hace en la Península donde "las manifestaciones de estas culturas se consideran mayormente como valores de interés turístico" (García 46). Es una visión de lo oriental que tiene puntos de coincidencia con visiones que en otro momento desarrollaron intelectuales que también estuvieron en el exilio, como es el caso del jesuita Juan Andrés (siglo XVIII) o el caso de expertos arabistas del siglo XX en España que defendían la importancia del período andalusí y la presencia musulmana en Europa como base para poder entender la realidad social, política y cultural de este continente. En lo personal, además, esta idea de oriente permite al autor vivir de una forma abierta y libre su orientación sexual en lo que podría considerarse su interpretación más romántica de ese orientalismo. Es en esto donde va a coincidir con muchos autores homosexuales que también eligen territorio norteafricano para establecer su residencia y escribir. La visión 
de Goytisolo sobre la cultura de Oriente reivindica ese punto de mestizaje, que supera las fronteras geográficas. Al sentirse cómodo en este nuevo lugar, toma aún más conciencia de lo importante que es denunciar a esa España franquista por haber expulsado o eliminado a quien se consideraba que no pertenece al modelo impuesto por la dictadura. Según el autor de Barcelona, la diversidad es lo que hace que se consiga la modernidad y cualquier elemento o ideología que ataque este principio, pone en peligro el avance de una nación. Como señala Iaian Chambers: "This alterity-Arabic, African, Asiatic, Islamic, Jewish- is a supposedly expelled, separated exteriority, and yet, as we have seen, it is historically and culturally intrinsic to the making of modernity" (2190). Reivindicación del conde don Julián puede ser entendida como ese ejercicio de negación de la visión única de país, de la visión única de forma de ser persona, es la puesta en valor de lo diferente en ese deseo de poner luz en todo lo que representa un punto de vista alternativo, donde puede tener cabida lo marginal. Esta novela representa la necesidad de destruir para volver a nacer, una novela que abre el paso al optimismo.

La ciudad y los perros de Vargas Llosa es una novela en la que podemos observar todo un mapa de comportamientos que nos permiten analizar, en primer lugar, la importancia que tienen las vivencias personales del autor y su relación con la obra narrativa que crea en sus novelas. No obstante, como escritor de la generación del Boom no hace en ningún momento valoración moral sobre los hechos que relata, aunque sí que nos deja ver cómo el modelo de masculinidad hegemónico toma cuerpo y se defiende de todo lo que le amenace utilizando distintas estructuras de control: la familia, el lenguaje, las conductas de rechazo hacia lo femenino y homofóbicas y la creación de estructuras de control como es el colegio Leoncio Prado. A pesar de todo este control, aparecen grupos 
que actúan saltándose la norma y generando estructuras paralelas que permiten ciertas transgresiones, siempre que éstas tengan lugar en el ámbito de lo oculto. La existencia de estructuras tan rígidas provoca la aparición de movimientos paralelos, como el círculo (grupo de cadetes en el colegio Leoncio Prado), que utiliza de también la violencia y la intolerancia para imponerse. Es toda una maquinaria diseñada para excluir a quien no cumpla con los preceptos del modelo de hombre que saldrá formado de dicha institución. El único espacio donde se puede ser diferente está siempre oculto: allí es donde Alberto puede escribir y donde puede hablar libremente de lo que se piensa.

En ambos textos se puede ver cómo ese modelo de comunidad imaginaria concebido por Benedict Anderson, cobra vida a través de los textos de Goytisolo y Vargas Llosa. Parte de la crítica señala que no es posible ver la literatura como una herramienta para definir la nación, y puede que esa crítica tenga parte de razón, pero lo que no es menos cierto es que en estas obras de ambos autores tenemos claros ejemplos en los que hay una intencionalidad expresacde mostrar qué males aquejan a las sociedades de los países de nacimiento de ambos, aunque el tono de la crítica sea distinto, por supuesto. Se trata también de dos personalidades literarias absolutamente distintas. Al hablar de nación también hablan de modelos de género, siendo la masculinidad hegemónica el que domine a esa idea de nación que hace del patriarcado el único sistema posible de organización. 


\section{CAPÍTULO IV}

Modelos alternativos de masculinidad en la obra de Mario Vargas Llosa y Juan Goytisolo.

En este último capítulo vamos a realizar un análisis pormenorizado de dos novelas que fueron publicadas por Mario Vargas Llosa y Juan Goytisolo. El sueño del celta y Juan sin tierra son dos trabajos que tienen como punto en común la inclusión de personajes que representan un modelo de masculinidad alternativo. En ambas obras podemos ver lo que acaba deparando socialmente a dos hombres que son un claro ejemplo de modelos alternativos de masculinidad ya que son homosexuales. Podremos ver qué ocurre con ellos y cómo afrontan sus diferencias en los entornos sociales a los que pertenecen. Aunque son dos trabajos que distan mucho en el año de publicación, la novela de Vargas Llosa fue publicada en 2010 y la de Juan Goytisolo en 1975, podemos decir que encontraremos situaciones parecidas en lo que respecta a cómo es tratada por la sociedad esta forma de masculinidad diferente al modelo hegemónico.

El sueño del celta (2010) es una novela en la que el protagonista es un diplomático británico de finales del XIX y comienzos del siglo XX, un personaje histórico conocido por su lucha por los derechos humanos de los indígenas de Perú y el Congo belga. A la vez, este personaje luchó activamente por la independencia de Irlanda del Norte y desencadenó una reacción popular al ser condenado a muerte por la corona británica tras ser acusado de traición. Esta acusación se produce tras descubrirse que había negociado en secreto con Alemania el traspaso de armas para los movimientos independentistas irlandeses siendo él diplomático del Reino Unido. En la novela se trata la complejidad del personaje, que además es homosexual. Es precisamente su orientación sexual lo que servirá de excusa para socavar la recogida de apoyos que respaldaran la 
petición de indulto por entender que él es un gran defensor de los derechos humanos. Vargas Llosa arranca el relato justo en el instante en el que Roger Casement está en su celda esperando saber si finalmente se aprueba o no su indulto. Es un texto que sirve para poder analizar cómo es determinante para el futuro de una persona su orientación sexual, sobre todo cuando se vive en el marco de una sociedad posvictoriana como la británica, en la que la cuestión de la vida sexual era prácticamente un tema tabú. Con el ejemplo de Roger Casement podremos desarrollar una serie de argumentos que nos servirán para mostrar cómo son tratados personajes masculinos que se mueven en los márgenes del modelo hegemónico de masculinidad.

En el caso de Juan Goytisolo, la novela que utilizaremos para el análisis será Juan sin tierra (1975). Es un trabajo muy personal ya que se adentra en cuestiones muy íntimas y tiene conexión con las dos obras publicadas previamente, Señas de identidad y Reivindicación. Ambos son analizados en dos de los capítulos de esta tesis. Al igual que la obra Vargas Llosa, en la novela de Goytisolo nos encontramos con un modelo alternativo de masculinidad. A lo largo del texto vamos a ver como el autor nos muestra a un hombre que decide afrontar sus diferencias con el modelo hegemónico masculino. Esta obra publicada se publica en el año de la muerte del dictador Franco, 1975. En ella se presenta una crítica mordaz a los valores que sustentan ese arquetipo masculino que fue defendido por la dictadura franquista. De nuevo, será la orientación sexual lo que determine qué ocurre en la vida de alguien que reconoce abiertamente su homosexualidad.

Es cierto que durante el siglo XIX los libros eran el elemento base para la socialización y la educación de la sociedad en los valores y formas que garantizarán la 
identificación de un modelo que protege los intereses de la nación y también del papel que se esperaba de quienes la formaban. Me refiero a los roles asignados a los dos géneros, el femenino y el masculino. Sin duda que autores de la generación del Boom latinoamericano nos ayudan a conocer con mejor perspectiva a personajes que en algunos casos pertenecen a sectores marginales de la sociedad, bien por su clase, por su origen étnico, su religión o su orientación sexual.

En El sueño del celta, el personaje protagonista será el que nos ayude en este análisis para valorar cómo se articula todo un sistema de control que censura, castiga y elimina cualquier atisbo de masculinidad alternativa, especialmente si se trata de alguien cuya orientación sexual va en contra de esa heterosexualidad. Coincide este aspecto en la novela del autor español, aunque la gran diferencia es que el personaje principal de Juan sin tierra, es él mismo. Es el mismo Goytisolo, ese Juan sin tierra que encuentra una forma alternativa de vida tras pasar por un proceso de involución y cambio personal que le lleva a hacer todo un manifiesto de intenciones para su futuro como persona y lleva a cabo una reinterpretación del mundo que le rodea. El texto contiene el relato de un cambio en lo personal que también pretende ofrecer alternativas y nuevas propuestas para la organización social y económica de la nación. El texto contendrá críticas despiadadas a la España colonial que explotó a los esclavos y se enriqueció con el trabajo de otras personas y también hará mofa de muchos personajes históricos que sustentan esa España más tradicional y ultracatólica en consonancia con la anterior novela de esta trilogía. Goytisolo ofrecerá alternativas y una de ellas es sí mismo, como alguien que reconoce abiertamente su homosexualidad y con ello se enfrenta a ese sistema supremacista de la masculinidad hegemónica en la que se cree que el hombre es el único sexo capaz de 
lograr vencer batallas. En este análisis de ambas obras utilizaremos teorías que nos hablarán de la hibridez y la mímesis que menciona Hommi Bhabha en sus ensayos cuando habla de la forma de evolución que han tenido países que han sido colonias de Occidente y cómo han desarrollado identidades propias, a pesar de que la metrópoli haya intentado que en ellas se reproduzca un calco de la cultura y del modelo social del país colonizador; también hablaremos del poder del deseo y el devenir de los cuerpos, así como de planteamientos teóricos novedosos que desarrollan argumentos para llevar a cabo lo que se denomina la contrasexualidad. A través de estas perspectivas teóricas encontraremos sustento para desarrollar una serie de argumentos que nos ayudarán a entender mejor esta masculinidad alternativa, qué ocurre con ella y como se muestra en al ámbito de las obras de los dos autores.

Roger Casement y Juan sin tierra, dos personajes individuales que en definitiva marcan una forma alternativa de percibir la sociedad y también la nación, porque como señala Leo Braudy:

The genesis of a modern theory of man in the state is thus inextricably interwoven with the theory of man in himself, how he lives and what he aspires to. The social self and its preoccupation with reputation-so important a theme in seventeenthcentury drama---is inseparable from the search for personal survival that helps create society. (164)

Este origen de una teorización sobre cómo es vista la masculinidad en el marco de un sistema de nación-estado comienza ya en el siglo XVII como señala Braudy, pero sin duda permanece a lo largo de los siglos siguientes, incluso en nuestros días. El individuo sigue una serie de pautas que harán que en ese comportamiento personal podamos leer lo que socialmente se espera de una persona que pertenece a una nación y apreciar las 
consecuencias que tiene el hecho de romper con la heteronormatividad o con la forma de ser hombre que no se ajusta al modelo hegemónico.

Comenzaremos analizando la novela El sueño del Celta para llevar a cabo una reflexión sobre las formas de representación de la masculinidad que podemos encontrar en ella. Partiremos este análisis desde la celda donde se encuentra preso su protagonista, Roger Casement. Él fue uno de los líderes del independentismo irlandés en el momento en que su verdugo procede a atarle las manos para conducirlo a la horca antes de que se ejecute la sentencia de muerte decretada por el Gobierno británico para el que prestó servicios como cónsul en África y en misión diplomática en Perú. Como comentamos en la introducción, esta novela contiene el relato sobre el diplomático británico que alcanzó prestigio mundial tras hacer una investigación in situ y redactar dos informes que condenaban la actuación abusiva contra los derechos humanos en el Congo por parte del rey de Bélgica, Leopoldo II y otro, para denunciar los abusos en esta misma materia por parte de la dirección de una empresa británica que se dedicaba a la recolección de caucho en los campos de la Amazonía peruana. Era un arduo defensor de los derechos humanos y a pesar de tener una posición privilegiada en los servicios a la corona británica, su cargo de alto diplomático no le valió en ningún momento para salvarse de su condena a muerte. Fue acusado de traición tras haber sido descubierto por los servicios secretos de Scotland Yard que él fue uno de los asistentes a la negociación con Alemania para obtener armas para la revuelta organizada por grupos independentistas irlandeses contra el Imperio Británico. Todo apunta en el transcurrir de la novela que el delito de traición será el que desencadene su acusación oficial, pero hay algo que acaba de frustrar los intentos de solicitud de indulto que se iniciaron a nivel internacional para presionar al reino británico 
y lograr el indulto para Casement. Lo que hizo que no hubiera posibilidad de salvación fue la revelación pública de la homosexualidad del diplomático. Esta cuestión acabó con cualquier esperanza de conseguir el indulto ya que era un asunto socialmente imperdonable; su orientación sexual será, finalmente, el detonante para que esa ejecución se llevara a cabo. Se trató por tanto de un juicio paralelo que puso en evidencia que Roger Casement había sobrepasado un límite moral inaceptable en una sociedad conservadora y defensora de los valores de una masculinidad que en ningún momento podía identificarse con esta forma de comportamiento sexual. Un servidor de la nación, ya sea la británica, o ya sea la irlandesa, no puede ser alguien que no se ajuste al patrón establecido bajo el modelo de masculinidad hegemónica. Ante esta distorsión, la sociedad pondrá en marcha todas las herramientas de control necesarias para eliminar a quien no se ajuste a dicho modelo. No se puede negar que en una comunidad o en una nación vamos a encontrar diversas formas de masculinidad, pero en lo tocante a personas con responsabilidades públicas en nombre de ese estado-nación, tan sólo existe una forma posible de masculinidad aceptada. Como señala Brittan, en el momento en que establecemos el vínculo con la nación, con el poder; tan sólo nos encontramos con un modelo aceptado y este ha de ser heterosexual, ya que es el único que se entiende que podrá garantizar la continuidad del patriarcado.

Por la estructura narrativa del texto se podría hablar de una novela posmodernista. La historia que se relata se enriquece por la estructura narrativa que el autor utiliza. Se puede decir así que estamos ante una novela que entronca con la teoría poscolonial; se puede apreciar en ella esa característica del posmodernismo del que Helen Carol WeldtBasson habla al señalar que dicho movimiento se inspira en el concepto de la diferencia; 
reconoce las diferencias de clase, raza, orientación sexual y facilita la deconstrucción de oposiciones binarias, para dar paso a la inclusión de una mayor variedad de opciones. Es una idea que también la comparte Linda Hutcheon y forma parte de otra serie de características que pretenden fundamentar la evolución que ha tenido la narrativa de ficción de los últimos tiempos. En El sueño del celta se da voz a quienes han sido oprimidos. Se muestra la vida de los desheredados, de los explotados, de la raza negra que vivió en las colonias europeas; se muestra la vida de un protagonista que vive su homosexualidad de forma oculta, un hombre que a lo largo del texto adquiere diferentes formas de comportamiento, alguien que trabajaba del lado de los colonizadores y que de pronto, se presenta como colonizado. ${ }^{38}$

La trama se desarrolla en tres lugares: la colonia belga del Congo, el antiguo virreinato del Perú donde hay intereses económicos británicos para la extracción del caucho y en Gran Bretaña, lugar de origen del protagonista. La forma en la que los personajes intervienen y la presentación de esta diversidad nos hacen ver el texto de Vargas Llosa también como novela poscolonial ya que sirve de vehículo para poder hacer visibles las formas de vida de las personas que fueron explotadas directamente por los responsables de gobernar las colonias en América y África, así como la vida oculta del protagonista, que tiene sus experiencias sexuales con hombres jóvenes en baños públicos. También se trata de una novela de contenido histórico, entendiendo este género como lo define Celia Fernández Prieto:

\footnotetext{
${ }^{38}$ Roger Casement es un alto funcionario del Imperio Británico y forma parte de ese aparato diplomático que supuestamente defiende los intereses de la metrópoli. A lo largo de la novela, pesa en él su solidaridad con los más débiles y el hecho de conocer en profundidad las dificultades de los pueblos colonizados, hace que nazca en él la solidaridad también con el pueblo irlandés, que en estos momentos mantiene un litigio con la corona británica y con el que tiene vínculos familiares, ya que su madre es de origen irlandés.
} 
Historias alternativas, apócrifas o contradictorias sobre sucesos personajes de gran relevancia histórica: De hecho, estas novelas presentan los hechos desde la perspectiva de los perdedores, de las minorías marginadas o excluidas de la historia, mostrando así que privilegiar una tradición textual implica aceptar una específica versión de la realidad histórica a expensas de otras versiones diferentes. (150)

Weldt-Basson habla de un subgénero que denomina "novela histórico simbólica" y sitúa en él a esta y otras novelas de Vargas Llosa. Este tipo de género se caracteriza por utilizar hechos históricos que sirven para situar la trama de una novela. Sus personajes tienen conexión con esos hechos del pasado, pero el autor toma la licencia para añadir elementos de ficción a cada uno de los personajes que aparecen en el relato. Vargas Llosa ya lo hizo con La fiesta del chivo al hablar de la dictadura de Trujillo en la República Dominicana, estableciendo un paralelismo con el gobierno de Fujimori en Perú. Incorpora personajes de la ficción inspirados en personas reales de la actualidad peruana de ese momento que se mezclan con los personajes históricos. Este género narrativo tiene dos dimensiones y Vargas Llosa lo utiliza para dar más veracidad a su obra y también para comparar personajes que en el caso de la novela sobre el dictador dominicano, sirven para criticar abiertamente las actuaciones del gobierno peruano del presidente de origen japonés.

En El sueño del celta vamos ver cómo se va a comparar la situación vivida por los indígenas de las colonias del Congo y de Perú con la situación que vive Irlanda del Norte que aparece en el texto como una comunidad oprimida por la corona de Gran Bretaña al no aprobar sus independencias. Vargas Llosa, a través de la visión que sobre este tema irlandés relata el protagonista, Roger Casement, estará planteando una comparación en la base del conflicto, tratando a Irlanda del Norte como si fuera una colonia de Gran Bretaña. Se utiliza la historia en esta novela como recurso para la crítica y la comparación 
de situaciones injustas vividas por comunidades dependientes de la Corona Británica. Como dice Weldt-Basson, hay todo un movimiento en la novela latinoamericana que se sitúa en el discurso poscolonial y utiliza este nuevo género para reflexionar sobre los abusos que se han padecido en diversos países de América del Sur o en otros lugares del mundo dando voz a los oprimidos y ayudando a establecer paralelismos entre territorios como hace de forma magistral Vargas Llosa en este caso. Con estas nuevas corrientes dentro de la narrativa poscolonial hay cabida para conocer mejor la realidad de los colonizados, o de los refugiados políticos, además de todos aquellos colectivos que padecieron la dominación por ser considerados inferiores a las civilizaciones que conquistaron esos territorios. La situación de los explotados en el Congo por parte de la corona belga o la situación de los recolectores de caucho en la selva peruana vista desde el punto de vista de quienes fueron abusados, toma protagonismo en el relato que se hace en El sueño del celta; de igual forma, podríamos considerar al protagonista como alguien que finalmente padece esa marginación y ese azote de un estado que obviará sus servicios como diplomático comprometido con los derechos humanos. La novela trata por tanto, la historia de alguien que al moverse fuera de los límites de la legalidad y también de la moralidad de la época, acaba siendo un perdedor.

Como es habitual en la obra de Vargas Llosa, en esta novela también tendremos una forma original de estructura del relato con dos líneas temporales y varias historias que se irán alternando en cada capítulo de la novela. La obra contiene tres relatos distintos: el de la experiencia del protagonista en el Congo, el ocurrido en la Amazonía y el relato de sus últimos encuentros, recuerdos y reflexiones en la celda donde está preso tras ser condenado a muerte por traición. El manejo de los tiempos es lo que da 
intensidad al desarrollo de la historia. Hay un salto continuo de un momento ocurrido en el pasado al momento presente. Las historias que ocurrieron en el pasado de la vida del protagonista nos ayudarán a entender mejor lo que está pasando en su presente. Este uso del tiempo tiene una funcionalidad semántica, nos permite entender mejor el significado de la novela y el porqué de todo lo que va ocurriendo a lo largo de ella. Sobre esta cuestión del tiempo habla Barthes cuando dice: "from the point of view of narrative, what we call time does not exist, or at least only exists functionally, as an element of a semiotic system" (99). Son muchos los indicios ${ }^{39}$, según la definición de Barthes, que nos sirven de catalizadores a la hora de construir la historia, a seguir esa estructura que salta de forma continua de un momento a otro pero que nos permiten seguir el hilo argumental de la narración sobre la vida de este líder del independentismo irlandés. Márquez nos dice que "la novela se va desarrollando, mediante la técnica de la alternancia o el contrapunto" (311). Es esa mezcla de planos temporales alternados a lo largo del relato y el uso magistral de indicios lo que ayuda a poder percibir la dimensión más personal del personaje, la sensibilidad del punto de vista del protagonista y las emociones que puede sentir en momentos tan duros como ser testigo de los maltratos de seres humanos o sus pensamientos y emociones en los momentos previos a ser ejecutado.

Vargas Llosa nos muestra cómo era el pensamiento del protagonista en momentos en que él era representante del Gobierno británico y él mismo compartía esa visión de supremacía sobre quienes vivían en las colonias. Casement dice: "Venir a África a

\footnotetext{
${ }^{39}$ Barthes habla de la existencia de unidades mínimas de significación en las narraciones. Una de ellas son los indicios que actúan como catalizadores a la hora de la interpretación de la historia por parte del lector. Que el protagonista de la novela tenga un encuentro con Arana, el gestor de las explotaciones de caucho en Perú, es una acción en sí, pero además es un indicio de la tensión que puede haber en un encuentro entre Casement y en este caso, la persona que es motivo de su denuncia por abuso contra los derechos humanos de los indígenas
} 
trabajar para mediante el comercio, el cristianismo y las instituciones sociales y políticas de occidente, emancipar a los africanos del atraso, la enfermedad y la ignorancia" (35). El diplomático británico tiene inicialmente esa idea de que todo lo que no fuera Europa, era sinónimo de salvajismo y necesitaba de la acción de los países europeos civilizados para entrar en una nueva etapa de desarrollo. Esa visión de Casement representa el imaginario que tiene Occidente sobre Oriente y del que Said nos habla en profundidad en su excelente trabajo sobre el Orientalismo, mencionado ya en capítulos anteriores de esta tesis. Nos habla de la visión del invasor. A la vez, quienes invaden, a pesar de considerar inferiores a las personas que viven en esos territorios, también sienten una gran atracción por quienes viven en esos lugares, los encuentran exóticos y diferentes. Finalmente, lo que hay es un interés meramente económico y de obtención de recursos naturales para poder mantener los niveles de bienestar de las sociedades europeas. Todo ello dio lugar a un discurso de nación basado en la supremacía sobre el otro. ${ }^{40}$ Roger Casement estaba convencido de esa necesidad de cumplir la misión de "civilizar" a los países colonizados. El personaje está posicionado en esta perspectiva al comienzo del relato. Es un momento de su vida en que sus visitas se acercan más al placer por conocer lo exótico de los lugares a los que iba, que a ser consciente de las consecuencias de esta actitud de explotación y marginación de los Otros. Si comparamos al Roger Casement del comienzo de la novela con el del final, somos conscientes del profundo cambio que se produce en su forma de actuar y analizar la realidad. Es muy interesante cómo evoluciona su percepción del Otro y sobre la situación de los colonizados conforme entra en contacto más profundo con la población originaria de esos territorios. Esto ocurre porque él tuvo

\footnotetext{
${ }^{40}$ Said hace un análisis a partir de textos literarios de países tradicionalmente colonizadores como Gran Bretaña y Alemania y como se presenta esa idea de Oriente desde la perspectiva de estas dos potencias europeas.
} 
que recoger testimonios directos de las personas que padecieron esa explotación, para conocer en profundidad la dimensión de los abusos ejercidos por las autoridades de la metrópoli. Son territorios donde había un interés económico por parte de Bélgica y de Gran Bretaña ya que extraían caucho para su industria.

El viaje al Congo tiene como propósito intentar averiguar la causa de una bajada fulminante del censo de población de los pueblos originarios en las zonas de recolección de este material y es en esa investigación sobre esta cuestión, cuando el protagonista de la obra experimenta un choque frontal que le hace consciente de que esa supuesta “liberación” mediante la aplicación de las normas de Occidente en las colonias, realmente ha acabado justificando la existencia de toda una estructura que lo que hace es violar los derechos humanos de los nativos de esos lugares para garantizar el enriquecimiento de los países colonizadores. Esta experiencia marcará un punto de inflexión sobre cómo percibe el proceso de colonización que Occidente ha hecho en sus colonias y las consecuencias que ha tenido esa idea de considerar de antemano al Otro, como un ser humano inferior. Casement experimenta en su persona dos emociones distintas: por un lado, él, al igual que otros muchos occidentales, sienten atracción erótica por los habitantes de estos territorios al ser considerados exóticos. Esto de alguna forma es una forma de dominio. De hecho, el diplomático mantenía encuentros sexuales con chicos muy jóvenes en los baños públicos, o en lugares sórdidos para que nadie pudiera descubrir sus gustos sexuales. Él mismo ejerce esa actitud de dominio sobre los menores. En segundo lugar, vive el acercamiento al ser humano que padece el abuso violento por parte de quien entiende que es una persona sin derechos por el simple hecho de pertenecer a otro territorio, a otra cultura, a otra raza y a otros ritos. Conoce a personas 
que han sufrido agresiones físicas e incluso han sido asesinados a manos de sus jefes, que son de raza blanca, o personas de su misma etnia, pero colaboradores activos de los colonizadores. El protagonista de la novela sería consciente del extremo violento de esa ambivalencia con la que se percibe a la población de las colonias, de ella nos habla Hommi Bhaba. ${ }^{41}$ Esa percepción del colonizado como alguien necesario para obtener beneficio económico, pero a la vez alguien subordinado por su condición de distinto. Es precisamente en esa percepción, como ser inferior, donde se fundamenta la aplicación del castigo cuando hay resistencia a hacer lo que el colonizador desea. Esa supremacía ejercida sin pudor, justificaría el maltrato. El capitán Massard con sus palabras confirma esta forma de percibir al Otro con el argumento para justificar el castigo con el chicote o la mutilación del pene de los congoleños que no obedecen las órdenes: "Hágales entender lo que son leyes y reglamentos a esos animales en dos patas. ¿no los conoce? Si lleva tantos años en el Congo debería. Es más fácil hacer entender las cosas a una hiena o a una garrapata que a un congolés" (88).

Lo que llama especialmente la atención en la evolución del relato es que Vargas Llosa muestra que la consecuencia que tiene el viaje al Congo sobre el comportamiento de Casement, es que él toma conciencia de sí mismo como alguien que está padeciendo el mismo trato que los congoleños por parte de un gobierno opresor como el británico al no permitir la autodeterminación del pueblo irlandés con el que él se siente unido. El origen familiar por parte materna es católico irlandés. Es algo que a lo largo de su vida va a

\footnotetext{
${ }^{41}$ Homi Bhabha representa a la segunda de las corrientes europeas que interpretan el poscolonialismo. Entre los conceptos que desarrolla está el de la ambivalencia que bebe del psicoanálisis de Freud y que consiste en la existencia de una doble perspectiva en la percepción que sobre las personas pueden tener los otros. Uno puede ser objeto de deseo para otros y a la vez ser rechazado por el mismo grupo por considerarlo inferior.
} 
pesar en su comportamiento y en su conciencia, de ahí que su trabajo influya en su forma de percibir esa nacionalidad heredada por parte materna. Él mismo confiesa en una carta a su prima Gee diciéndole: “Tengo la impresión de haber mudado la piel, como ciertos ofidios, de mentalidad y acaso hasta de alma" (109). El uso de la palabra, alma, en su sentido religioso, tiene completo significado porque en ese proceso de cambio hay una reafirmación en su fe católica, seña de identidad clave en el independentismo irlandés. Casement se da cuenta de que forma parte de una cultura distinta a la mayoritaria en su país de nacimiento y, además, se encuentra con la paradoja de que presta servicios al país en el que se ha educado y del que ha recibido una serie de ideas y principios con los que de pronto no se sentirá identificado. Reconoce en sí mismo una serie de rasgos irlandés es que le hacen consciente de la diferencia; es como si se encontrara inmerso en un entorno con el que ya no se siente plenamente identificado. Bhabha habla de un fenómeno que él denomina mímesis y que consiste en cómo los colonizados por la metrópoli son formados para ser un ejemplo exacto de los valores de la cultura colonizadora, pero cuando dan lugar a la reproducción de esos valores culturales, será inevitable apreciar un elemento que les hará diferentes, ya que su origen y su cultura previa antes de la llegada de los colonizadores, están ahí presentes. Pueden repetir esos principios recibidos por parte de la cultura de la metrópoli, pero siempre tendrán cualidades que les harán distintos a los que les invadieron. Bhabha lo explica así: "Un deseo que, mediante la repetición de la presencia parcial, que es la base del mimetismo, articula esas perturbaciones de la diferencia cultural, racial e histórica que amenaza a la demanda narcisista de la autoridad colonial" (115). Ese pueblo colonizado imitará los saberes y principios a imagen y semejanza del colonizador, pero nunca será una copia exacta de éste. Esos elementos 
autóctonos son lo que marcarán la diferencia con respecto a quienes llegaron desde fuera. Roger Casement experimenta esa toma de conciencia de ser distinto aún a pesar de haber sido instruido y formado en la sociedad británica. Su origen irlandés y la influencia de la religión católica a través de su madre, le harán alguien que de pronto se transforma en Otro, alguien diferente. Casement acaba rebelándose contra lo que considera un abuso sobre una parte de la población que depende de la colonia británica y que no es respetada por su confesión religiosa distinta a la oficial además de por sus reivindicaciones territoriales. Él toma conciencia sobre esta situación y acabará enfrentándose a la corona británica, que es para quien ha estado trabajando durante años. El diplomático acaba sintiéndose como el colonizado, al que tuvo la oportunidad de conocer en África y América. Se reconoce a sí mismo también como una víctima de esa opresión que ejerce el estado sobre quienes son considerados enemigos o quienes pueden poner en peligro la unidad de la nación. La diferencia entre él y el pueblo originario congoleño con el que tiene contacto por su trabajo es que en este caso él mismo forma parte del núcleo de poder de esa nación opresora: él mismo ha sido sujeto activo durante un momento de su vida en ese proceso de instrucción en valores occidentales traspasados por obligación a los pueblos originarios de las colonias. Como comentamos antes, él mismo pensaba que eso era necesario al tener la idea de que esas poblaciones estaban atrasadas tecnológica y culturalmente, con respecto a Europa. Acaba enfrentándose a sí mismo, él es el colonizador colonizado.

Si el viaje al Congo sirve a Casement para identificarse con los sentimientos que tienen los colonizados de este país, su experiencia en el Putumayo peruano desata en él 
esa idea de la necesidad de la violencia para poder obtener la independencia y liberarse del opresor:

Los irlandeses somos como los huitotos, los boras, los andoques y los muinanes del Putumayo. Colonizados, explotados y condenados a serlo siempre si seguimos confiando en las leyes, las instituciones y los Gobiernos de Inglaterra, para alcanzar la libertad. Nunca nos la darán. ¿Por qué lo haría el Imperio que nos coloniza si no siente una presión irresistible que le obligue a hacerlo? Esa presión sólo puede venir de las armas. (239)

Como plantea el psiquiatra Frantz Fanon, la violencia puede ser el medio para poder establecer un nuevo nivel de negociación entre el colonizado y el colonizador. Esta es la conclusión a la que también llega Casement tras pasar por ese proceso de cambio a nivel personal. De hecho, justifica que la situación irlandesa requiere de la fuerza armada para seguir adelante y comienza a actuar en esa dirección con su negociación para conseguir apoyo por parte de Alemania en el intento de conseguir armas para los grupos independentistas irlandeses. Esta es la causa por la que finalmente se le condena a muerte, ya que este acto contra los intereses del gobierno del Reino Unido es considerado alta traición.

Son varios los elementos que a lo largo de este análisis nos permiten comprobar que el personaje protagonista de esta novela es un tipo de hombre distinto al modelo hegemónico. Son pocos los personajes femeninos que aparecen en el texto. ${ }^{42}$ A través de la novela podemos entrever un modelo masculino representado por Roger Casement en el que se puede distinguir cierta ambivalencia. Por un lado, se espanta ante la violencia que

\footnotetext{
${ }^{42}$ La figura de la madre de Roger Casement que muere cuando él era niño aunque siempre está presente en su mente por haber influido de forma notoria en su convicción religiosa como católico. Ella protagoniza un elemento de transgresión en la vida del protagonista al bautizarle sin el consentimiento de su padre. Otro de los personajes femeninos es la historiadora Alice Stopford Green, especialista en historia de Irlanda y miembro activo del movimiento independentista irlandés. Apoya hasta los últimos momentos a Roger Casement acompañándolo en sucesivas visitas a la cárcel y notificándole cómo va la campaña de recogida de firmas internacional que se organizó para solicitar su indulto sin que finalmente surtiera efecto. El tercer personaje femenino que aparece en la historia es Gertrude Gee que es su prima y a quien se confiesa sobre su vida privada y e su evolución ideológica. Salvo estos tres; el resto son personajes masculinos.
} 
los colonizadores ejercen sobre el colonizado y con el paso del tiempo, en su toma de conciencia del dominio británico sobre Irlanda, acaba defendiendo el uso de las armas para conseguir la liberación del pueblo irlandés ante la opresión que ejerce sobre él Gran Bretaña. Socialmente, es una persona aceptada y reconocida en los círculos profesionales y laborales donde presta sus servicios. Su homosexualidad no será un problema a lo largo de su carrera mientras que no se trate de algo de dominio público. Como señala Guy Hocqhenheim: "Homosexuality is placed under the sign of quiet and transgression" (94). Por lo tanto, él no es rechazado por su condición de homosexual mientras esta se desarrolle sin que nadie sepa de ello. Esto es algo común en una Gran Bretaña muy conservadora. Es por ello que no tiene a lo largo de su carrera ningún problema de rechazo que afecte a su carrera profesional. Es más, el mundo en el que él se mueve es un mundo masculinizado, puesto que pocas mujeres habían formado parte de la carrera diplomática a comienzos del siglo XX.

El hecho de que Casement tenga el apoyo de su gobierno en las misiones que lleva a cabo, le sirve de protección en todo momento ya que está bajo la inmunidad diplomática que el sistema le proporciona. Como es habitual, él huye de su homosexualidad. Es algo que mantiene oculto en su vida pública, aunque lo comparta con su círculo más personal e íntimo. Es habitual esta actitud, teniendo en cuenta que vive en una época en que la homosexualidad es considerada una enfermedad, una forma de anormalidad en el comportamiento humano que ha de ser curada o castigada por considerarse una amenaza a la esencia del patriarcado. Como señala Mosse "It was the doctors who did the most to stimulate awareness of homosexuality as a social concern" (27). El paso del tratamiento de la homosexualidad a manos de la medicina marca todo un 
proceso de represión contra las personas que tienen esta orientación sexual. En el texto podemos conocer las estrategias que él sigue para disfrazar la forma en la que practica su sexualidad. Eso sí, escribe notas para dejar constancia de sus aventuras sexuales y esto es lo que finalmente le generará problemas. Hace fotografías de las personas objeto de su deseo y de los lugares donde se encuentra con ellos. Como dice Perlongher, el deseo es algo que incorpora lugares, momentos concretos y lo que se hace con personas específicas. Casement utiliza la fotografía para revestir de interés estético su deseo sexual y visita baños púbicos donde intenta conseguir encuentros esporádicos. Vargas Llosa reproduce parte de esa experiencia homosexual basándose en los diarios personales de Casement, los cuales, aún hoy, suscitan mucha polémica por desvelar un comportamiento oculto de alguien que tenía una gran reputación social. Por supuesto, si se hubiera conocido públicamente todo lo que el diplomático hacía, su carrera habría estado acabada muchísimos años antes de lo que finalmente duró. Existe un miedo que impide poder compartir públicamente la orientación sexual, pero hay una vía de escape que es la autonegación personal de cómo se vive ese deseo sexual. El diario personal de Casement es la forma de registrar en un soporte físico, lo que se está viviendo psicológicamente. A través de este diario da forma material a sus vivencias personales. En el fondo, es una persona temerosa del qué dirán y su actitud puede interpretarse con una afirmación de Foucault que dice que la homosexualidad asusta a las personas más como forma de vida que como una forma de tener sexo. El hecho de la atracción por los jóvenes de los países que visitaba será objeto de gruesas críticas. De hecho, Welt-Basson acusa a Roger Casement de caer en esa actitud del colonizador que acaba percibiendo a los colonizados como personas que están a su servicio. En el imaginario de Occidente se considera que 
todas las formas de sexo pueden ser posibles en esa parte del mundo, en contraposición a la rigidez de las sociedades europeas; en este caso, de la sociedad inglesa que aunque se encuentra ya a principios del siglo XX mantiene aún una actitud muy victoriana sobre este asunto. Cuando la nación planifica normativas para el crecimiento de la población, reprime duramente todas aquellas relaciones que no tengan como fin la reproducción. Es normal que Casement se oculte o practique sus deseos más íntimos en el silencio, pues no quiere ver amenazada su vida profesional. La sociedad británica no puede tolerar que una forma distinta de ser hombre, sea consentida y refrendada con un indulto a alguien que no sólo ha traicionado a la patria por sus negociaciones ocultas con los alemanes, sino también, por su homosexualidad. Se trata de un traidor y según el momento en que vivía, también era un enfermo.

En este caso, tomando la idea del panóptico ${ }^{43}$ del que nos habla Foucault se nos da otro caso de ambivalencia. Casement es parte de esa torre de vigilancia al pertenecer al aparato de poder que controla al resto de la sociedad (sus visitas al Congo y a Perú tienen como fin vigilar, informar y sancionar) y en lo que respecta a su vida íntima, él pasa a ser una de las víctimas de ese sistema de sanción y control por no cumplir con los requerimientos que el sistema patriarcal demanda de sus hombres. Es Scotland Yard el organismo que ejerce su poder para debilitar al diplomático británico. Lo hace publicando sus diarios para prender la mecha en la opinión pública y provocar ese rechazo general en la sociedad al dar a conocer públicamente su homosexualidad. El hecho de hacer este secreto de dominio público provoca que haya personas que, aunque conocían su orientación sexual, no pueden exponerse públicamente mostrando su apoyo porque de alguna forma, quienes lo hagan, también serán rechazados y sancionados por el sistema.

\footnotetext{
${ }^{43}$ Ver Capítulo 3 de esta tesis.
} 
De ahí la afirmación que hacía anteriormente sobre el hecho de que es su homosexualidad lo que realmente acaba llevándole a la pena de muerte. Casement será traicionado por uno de sus amantes, el joven noruego Eiven Adler. Éste le seduce para ganarse su confianza, siente por él admiración y deseo, para después delatarle ante las autoridades británicas por la negociación que llevó en secreto con Alemania en su intención de buscar apoyos para los movimientos independentistas irlandeses. El protagonista es víctima de un deseo que ni siquiera pudo hacer realidad. Cayó en la trampa de verse vencido ante un amor platónico hacia Adler, una relación que nunca se vio consumada, pero que dio al joven noruego el arma más poderosa para acabar con la existencia del diplomático británico. El sistema, por tanto, no sólo sanciona la práctica sexual con personas del mismo sexo, sino que también condena el deseo que uno pueda sentir hacia esas personas. Es decir, cualquier forma de ejercer esa homosexualidad (física o de pensamiento) es rechazada, condenada y por supuesto, castigada.

Casement es un representante de la nación británica, por lo tanto, su forma de comportarse en su vida privada, será controlada exhaustivamente. Como señala Leo Braudy en un excelente análisis sobre la idea de la masculinidad y la nación: "Like a knight in armor, the pure nation is the encased nation, making itself ready for warfare by purging whatever races and peoples it deems not to correspond to its idea of itself" (135). Esa purga que menciona Braudy se hace efectiva en el relato de Vargas Llosa. La sociedad y el sistema patriarcal se darán armas para luchar contra todo lo que arriesgue la ideología que sustenta ese sistema. Esta idea de quienes han de estar y quiénes no, también la manifiesta George Mosse cuando dice: "Nationalism and respectability assigned everyone his place in life, man and woman, normal and abnormal, native and 
foreigner, any confusion between these categories threatened chaos and loss of control" (16). La reacción del sistema ante alguien que traiciona a la nación es inmediata.

En el caso del protagonista de El sueño del celta podemos decir que es apresado por doble traición: primero, por intentar dotar de armas a los grupos independentistas norirlandeses y segundo, por no cumplir con el modelo de masculinidad que socialmente es aceptado. Lo que procede hacer, por tanto, es encerrarlo, juzgarlo y por supuesto, ejecutarlo. Podríamos preguntarnos ¿qué habría ocurrido si el protagonista hubiera tenido un pasado de múltiples relaciones con mujeres, en vez de con hombres? Si hubiera sido un hombre conforme a la norma, ¿habría seguido teniendo problemas para recibir el apoyo público de personalidades del mundo de la política o la cultura a nivel internacional? ¿Es posible un modelo de nación en que se incorporen otras formas de masculinidad que sean distintas al modelo hegemónico? Como dice Todd W. Reeser, "One might gender a nation by analogy with the gender of its leader, or a leader may act in a certain gendered manner in order to gender the nation by analogy" (173). La publicación de los diarios deja en evidencia al supuesto líder y ataca la línea de flotación de lo que podríamos entender como aceptable en un hombre de relevancia pública como era Casement. Se desvela que su comportamiento sexual no se encuentra dentro del rol establecido para quienes tienen y desean gestionar el poder. Se aceptó mientras ocurría en la esfera de lo privado, pero todo cambiará a partir del momento en que es de dominio público. Esa forma de hipocresía consentida es propia de una sociedad que es capaz de mirar a otro lado si no hay pruebas evidentes de lo que realmente ocurre.

El nacionalismo que propugnaba Casement tiene que ver con la idea de Simon During que entiende a éste como una forma de liberación con respecto al Imperio y como 
también afirma el mismo autor, uno podría ser nacionalista sin ser imperialista. Es en esa dimensión donde sitúa su postura el protagonista: él entiende que el nacionalismo irlandés será el que permita dar voz y poder a los "colonizados" de cualquier territorio; se trata de ese primer momento en que las nuevas naciones surgen con la intención de desvincularse de un poder que hasta ahora las ha hecho sentirse oprimidas porque no tienen capacidad de decisión política autónoma. Puede incluso que el propio Casement también hubiera sido rechazado igualmente por esa ansiada nación irlandesa ya que él no cumplía con ese modelo hegemónico masculino que se espera que todo miembro masculino con poder ha de respetar y llevar a cabo. Por lo tanto, él fue ejecutado por traidor y por no ajustarse al modelo.

Tras analizar la forma en que son tratados personajes que representan un modelo alternativo de masculinidad en la novela de Vargas Llosa, ahora vamos a detenernos en la obra de Juan Goytisolo para analizar también esta misma cuestión. Cuando analizábamos Don Julián se pudo comprobar cómo hay un especial interés por parte del autor, en ironizar y ridiculizar al personaje histórico de Isabel la Católica que es uno de los ejemplos de mando que toma la dictadura fascista de Franco. La reina era el personaje histórico que simboliza la idea de unidad política y territorial nacional que fue identificada como la máxima a conseguir por parte de la sociedad ultracatólica española tras el golpe de estado del General Franco. Un ejemplo de este ataque irónico a dicho personaje histórico, es el que hace el narrador cuando, de forma provocadora, hace una interpretación muy personal de la supuesta vinculación entre el personaje protagonista de la novela y la reina de España. Como señala Gema Pérez:

Through the metonymical connection between Isabel la Católica and Alvarito (mother and son), the narrator repeatedly rapes Alvarito. In a sense, first 
through the rape of the mother and then through the sadomasochistic encounters between the snake charmer/Julián and Alvarito, the protagonist both enacts a rape of Spain and submits to being sodomized by it. Ultimately, though, Goytisolo's use of sodomy is politically strategic: by sodomizing Alvarito, Don Julián seeks revenge on Francoism; he attempts to mirror, or to do back to the dictatorship what it had done to the general population, that is, to place it in the passive, bottom position. (90)

No podemos olvidar que el motivo del exilio de Goytisolo fue la gran presión que recibió por parte del régimen franquista, así como la crítica feroz a su obra, tal como comentamos en capítulos anteriores. Álvaro apenas es citado en la tercera parte de la trilogía, es como si este acto de "violación” simbólica del que nos habla Pérez marcara el final de un estado psicológico para dar lugar a una nueva etapa. Se trataría de la reinvención de un nuevo personaje. De hecho, cuando se menciona al protagonista en el último libro de la trilogía, se hace como si no se tratara de alguien cercano cuando dice: "las preces y antífonas de los fieles reatan la paulatina transformación del lugar y el olor a incienso de su niñez (del otro, del muerto)" (711). Es un recuerdo de alguien que, llegado este punto del relato, ya no existe. En ese proceso de destrucción no sólo se elimina lo más cercano, sino que también Goytisolo hace una extensa crítica del canon literario que asume como propio el régimen de Franco. A lo largo del texto el narrador hace desaparecer todo aquello que ha podido significar un lastre en ese pasado “carpetovetónico". ${ }^{44}$ Como señala Estrella Cibreiro: "En su ruptura con cultura, historia y tradición literaria el narrador busca no sólo su propia liberación, sino también la del lector y ofrece su obra como desafío y testimonio de su esfuerzo subversivo" (16). Son continuos los pasajes en esta novela donde se describe el papel que tiene la escritura en ese proceso de destrucción y reconstrucción. Esa reconstrucción es presentada de varias

\footnotetext{
44 Según la RAE, este adjetivo, se refiere a algo "considerado como característico de la España profunda frente a todo influjo foráneo".
} 
formas: como forma de lucha y defensa contra las injusticias, y como una forma de defender y dar a conocer la situación de los oprimidos. En el texto podemos encontrar afirmaciones sobre el significado del acto de escribir como la siguiente: "exorcizando demonios en lúdica confrontación sangrienta, sin más arma ni brazo que el discurso desnudo: transmutando la violencia en signo: barriendo su odiosa faz de la tierra: trocándola en motivo de justa verbal”. (663)

A lo largo de ese largo camino que nos lleva hasta este tercer libro se asiste a una muerte psicológica que se presenta como necesaria para dar lugar a un momento vital nuevo. Se trata de una muerte con esperanza, como bien describe el narrador al hablar de ella:

Augurio de una vida mejor y más libre, lejos de la funesta península y de su aletargada fauna: con aguda y enigmática sencillez: sedativa diana que inaugura el nuevo día, compensación y antídoto del brutal despertar: apostado en el chaflán como de costumbre, fuera de tu campo de observación. (90)

Juan sin tierra tiene ese valor de proyecto de futuro. Hay hechos que se refieren al pasado, pero también aparece mucho de lo que será el proyecto de vida en lo personal y el proyecto literario que se pretende desarrollar. Precisamente encontramos un pasaje en el que se habla de las características principales que tendrá ese proyecto literario de futuro cuando leemos: "eliminar del corpus de la obra novelesca los últimos vestigios de teatralidad: transformarla en discurso sin peripecia alguna: dinamitar la invertebrada noción del personaje de hueso y carne: substituyendo la progressio dramática del relato por un conjunto de agrupaciones textuales movidas por fuerza centrípeta única: núcleo organizador de la propia escritura" (717). Como venimos manteniendo hasta ahora, se trata de una trilogía catártica en la que no sólo hay una revisión de lo personal, de lo 
histórico o de lo social, sino también de la forma de escribir y del uso de la palabra. El narrador nos cuenta: "no basta con echar por la borda rostro, nombre, familia, costumbres, tierra: la ascesis debe continuar: cada palabra de su idioma te tiende igualmente una trampa: en adelante aprenderás a pensar contra tu propia lengua" (649).

En este tercer volumen se produce un punto de inflexión con respecto a Don Julián. De hecho, a partir de la primera página podemos ver la fuerza que tienen las palabras, que en este caso nos permiten traducir una sensación de tranquilidad interior del narrador en contraste con el lenguaje violento utilizado en las dos novelas anteriores de la trilogía. Comienza esta tercera obra diciendo: "según los gurús indostánicos, en la fase superior de la meditación, el cuerpo humano, purgado de apetitos y anhelos, se abandona con deleite a una existencia etérea, horra de pasiones y achaques, atenta solo al manso discurrir de un tiempo sin fronteras" (597). En este fragmento se anticipa gran parte del contenido posterior de la novela. Al hablar del "cuerpo purgado de apetitos y anhelos" puede interpretarse como que ya se ha alcanzado el momento idóneo para reinventarse, una vez que se ha agotado ese período en el que la experimentación para obtener respuestas era lo esencial. Ahora es distinto, es el inicio de un tiempo en que las pasiones no tendrán más límite que el que venga marcado por el tiempo y su práctica no generará ningún tipo de cargo de conciencia. Precisamente teniendo en cuenta esa visión de futuro que recoge el texto de la novela sugiero una lectura de la misma a la luz de dos de los principales teóricos queer del mundo hispanoamericano. Primeramente, Beatriz (Paul B.) Preciado, centrándonos en su idea de reinvindicación universal del ano. Un pensamiento que tendrá como consecuencia principal el hecho de romper con constreñimientos de género construidos alrededor del significante heterosexista por antonomasia, el falo. En segundo 
lugar, el teórico y novelista argentino Nestor Perlongher y algunos de sus conceptos sobre el devenir del deseo, los puntos de fuga o la red de flujos, los cuales beben en gran medida de las teorías desarrolladas por Deleuze y Guattari. ${ }^{45}$ Se trata de entrar en un diálogo con el texto de Goytisolo para hacer una interpretación de cómo el autor español establece un punto de inflexión al escribir esta obra. Tendrá una visión de futuro al abordar la novela, tal como dice Brad Epps: "Juan sin tierra, more than any Goytisolo's texts, pushes at the codes of realist representation. Fragmentary, discontinuous, and wild, it celebrates the sheer heterogeneity of existence, the vitality of the present, the possibilities of the future" (127). El hecho de que Goytisolo muestre abiertamente en esta novela aspectos de su homosexualidad, nos permite hacer un análisis en base a la teoría queer. $^{46}$

Iniciamos este camino con Manifiesto contra-sexual, donde Preciado propone el concepto de contra-sexualidad como teoría que ayudará a reinterpretar los cuerpos biológicos y su relación con el género. En el prefacio de este libro, la teórica española Marie Heléne Bourcier comenta la novedad del manifiesto cuando dice: "Este manifiesto pone el acento precisamente sobre aquellas zonas olvidadas por los análisis feministas y queer: El cuerpo como espacio de construcción biopolítica, como lugar de opresión pero también como centro de resistencia" (12). El cuerpo es siempre sujeto de interés político y en virtud a él se estructura toda una política económica y de organización social. Es

\footnotetext{
${ }^{45}$ Autores del Anti Edipo, obra que tiene gran incidencia en los pensamientos queer del momento En esta obra se analiza la influencia del capitalismo y cómo utiliza en su beneficio los mitos y representaciones que pueden serle útiles para su pervivencia. También abordan la posibilidad de la existencia de una sociedad sin órganos del cuerpo diferenciadores entre sexos y el papel que representa lo que denominan "máquinas de deseo" dentro de ese sistema capitalista.

${ }^{46}$ Es un humilde esfuerzo por demostrar esa idea que Brad Epps señala al decir que la academia americana no era la única que abordaba la situación de la homosexualidad y la lucha contra un modelo hegemónico que se ha empeñado en neutralizar todo lo que implique una amenaza. Veremos cómo hay muchos puntos en común entre la obra de estos teóricos y el autor español.
} 
precisamente en la interpretación del cuerpo que hace Preciado donde encontramos un elemento fundamental de su teoría. Preciado plantea una teoría revolucionaria sobre el género. De hecho, su novedad está precisamente en romper con el modelo de género establecido y que tiene los binarios como elementos de definición indispensables. Su concepto sobre los cuerpos humanos es el siguiente: "renuncian no solo a una identidad sexual cerrada y determinada naturalmente, sino también a los beneficios que podrían obtener de una naturalización de los efectos sociales, económicos y jurídicos de sus prácticas significantes" (19). A todo esto, podemos también añadir la idea del sexo como tecnología biopolítica o la importancia de considerar el cuerpo como un todo y no incidir en su división en partes para producir la diferencia entre unos y otros en función de si se tiene vagina, pene o no. Según Paul Beatriz Preciado, en una entrevista reciente en la televisión, menciona que "el cuerpo es un texto sacralizado" sobre el cual se ha impreso un discurso político de género y se ha controlado para que en todo momento no se desvíe de su función económico social que es la reproducción. En la obra de Goytisolo que estamos analizando aquí, se da lugar a una reescritura del cuerpo que nos va a hacer pensar en otras posibilidades, otras subjetividades, otros modelos que serán alternativos.

En el Manifiesto, Preciado propone "resexualizar el ano (una zona excluida de las prácticas heterocentradas, considerada como la más sucia y la más abyecta) como centro contrasexual universal"(30). Se trata de un planteamiento revolucionario ya que esto implicaría, entre otras muchas cuestiones, la subversión contra los dualismos de género. Paul B. Preciado se centra en esta parte del cuerpo y hace del ano un órgano que es igual en todos los seres humanos. No existen diferencias en función del sexo. En su texto Terror anal plantea además que es precisamente debido a la castración del ano por lo que 
se produce la aparición del "cuerpo privado" y a consecuencia de ello dice: "Así nacieron los hombres heterosexuales a finales del siglo XIX: son cuerpos castrados de ano" (136). Esta visión y análisis de la realidad implicaría la desvinculación de ese binario mujer/hombre o del de heterosexual/homosexual. Este punto de vista abriría automáticamente la posibilidad a cualquier otra forma de ser biológica y sexual que rompiera con esa continua dualidad excluyente que tanto daño ha hecho a lo largo de la historia. Como señala Preciado:

La contra-sexualidad es también una teoría del cuerpo que se sitúa fuera de las oposiciones hombre/mujer, masculino/femenino, heterosexualidad/ homosexualidad. Define la sexualidad como tecnología y considera que los diferentes elementos del sistema sexo-género denominados hombre, mujer, homosexual, heterosexual, transexual, así como sus prácticas e identidades sexuales no son sino máquinas, productos, instrumentos, aparatos, trucos, prótesis, redes, aplicaciones, programas, conexiones, flujos de energía y de información, interrupciones e interruptores, llaves, leyes de circulación, fronteras, constreñimientos. Diseños, lógicas, equipos, formatos, accidentes, detritos, mecanismos, usos, desvíos. (Manifiesto 19)

Nos plantea por tanto que, si la sociedad no se organizara en función de este sistema con tan sólo dos opciones, todo sería absolutamente distinto y se podría entender mejor la diversidad de formas que son posibles que se produzcan a lo largo de la vida de un mismo ser humano. Esta forma de organización obliga a una clasificación y también a establecer lo que puede ser aceptado socialmente y lo que no. Como señala el mismo autor en su texto Terror anal : "el ano nunca ha sido considerado un órgano sexual y es precisamente esto lo que lo relaciona también con la vagina, algo que incluso la Real Academia Española no ha definido tampoco como órgano sexual" (149).

La presencia del ano en el texto de Juan sin Tierra es constante, de hecho, encontramos en la revisión de la crítica sobre esta novela varios artículos en los que se analiza el papel de este órgano del cuerpo al analizar la novela. Como señala Epps "The arse, improper 
and unclean as it may be, functions in Goytisolo's text as the great equalizer, the sign of communal identity and of healthily public reconciliation" (152). Son varias las partes del texto donde encontraremos el ano como un símbolo que nos ayudará a hacer una interpretación de la sociedad y sus diferencias de clase y de raza. Precisamente encontramos en Juan sin tierra una denuncia sobre la diferencia de vida y trato entre blancos y negros. Esta denuncia se hace centrándose en una de las funciones que tiene el ano: la excreción. En el texto se hace hincapié en que da igual la raza o el género, el acto de la defecación es igual en todas las personas. El autor pone en boca del narrador la formulación de una serie de preguntas que permitan darse cuenta que el acto de la excreción es el mismo independientemente de quién lo haga. En un párrafo de la obra encontramos este cuestionamiento: "claro está que alguno de vosotros, dándoselas de listo, me vendrá a preguntar: el Redentor y la Virgen, no comían?: los Evangelios nos enseñan lo contrario: entonces, díganos, padre: qué se hacía de los manjares que consumían si no los evacuaban?: ah, hombres de poca fe!" (605). Goytisolo trata de evidenciar mediante estas palabras que si hay algo que nos hace iguales a todos los seres humanos independientemente de nuestra raza, sexo, clase social o religión. Con ello se pretende reivindicar la sinrazón de la existencia de desigualdades cuando la función de uno de nuestros órganos no tiene diferencia entre unos y otros. El acto de la defecación tiene carácter universal. Es una visión que acerca a Goytisolo y Preciado en la reivindicación de este asunto para establecer un elemento de unión entre grupos minoritarios o grupos marginales ya que esto haría que hombres o mujeres serían considerados en igualdad; al igual que la raza no sería un elemento diferenciador, tampoco lo sería la clase social. Quizá el aspecto más importante está en la supresión de 
las diferencias en función del sexo de las personas. Todas tienen este órgano y en todas las personas tiene la misma función biológica.

También vamos a encontrar en esta obra de la trilogía de Goytisolo un canto a la reordenación, a la resignificación y a la creación de un espacio que permita la aceptación de la diversidad de cuerpos y evite la marginalidad. Asistimos también a una denuncia en el texto de Juan sin tierra de esa diferencia entre quienes son considerados seres divinos y los que no, cuando el narrador dice:

Pues del mismo modo que el Ojo de Dios irradia luz y blancura, el ano bestial, el ojo del diablo emana infección y hediondez, suciedad y pecado: sus funciones son absolutamente excluyentes y opuestas: así nos lo dice el angélico Tomás de Aquino: lo que se corrompe en parte es corruptible en su totalidad y semejante eventualidad resultaría odiosa, sacrílega, incluso para los herejes más empedernidos. (604)

En esta cita se habla de cómo se puede encontrar dentro de ese sistema binario una clara diferenciación entre lo que es bueno y lo que es malo para conseguir de esta forma, identificar a quienes se encuentran fuera de lo aceptable socialmente. Más adelante, Goytisolo habla de que una conjetura. Si se hubiera considerado como fundamento teórico para la organización social la cuestión de que todos los seres humanos tenemos elementos que nos hacen iguales, la situación habría sido muy distinta. El narrador de la obra plantea estas cuestiones abiertamente cuando señala: "las emisiones viscerales, ya sólidas, ya líquidas, amén de las restantes eliminaciones corpóreas como pelos, sudor, uñas, saliva, mucosidades, deberían participar, en caso de que hubiesen existido, de la naturaleza divina del Hijo o sobrenatural y privilegiada de la Madre" (604-605). Si no se hubieran considerado los elementos divinos como distintos a los del ser humano, sino que se les hubiera percibido como más terrenales, muchos de los acontecimientos históricos que tuvieron lugar en nombre de ese dio, habría sido muy distinto. Todo habría cambiado 
si se hubiera llevado a cabo lo que el fragmento nos dice sobre la consideración de lo que tradicionalmente ha sido relacionado con lo abyecto ${ }^{47}$.

En Juan sin tierra, hay una mayor obsesión por la función de la defecación que por el órgano anal en sí. La función de defecar sirve como eje conductor para mostrar las diferencias sociales y hacer de ello un símbolo que también establecerá la diferencia entre Occidente y ese Oriente representado por todos aquellos que simbolizan la idea del Otro en la obra goytisoliana. Como dice Epps: "In the interplay of symbolism and reality, Goytisolo's excremental obsession functions as a form of cultural critique" (165). Las diferencias en la sofisticación de los lugares donde los seres humanos defecan es tratada también en la obra; los lugares donde lo hacen los esclavos tiene características distintas al lugar donde lo hace la gente que tiene el poder económico y político, los señores y las señoras. Los primeros lo hacen en zanjas comunes, mientras que los segundos lo hacen en el llamado toilet. Es el lugar donde se defeca, lo que establece la diferencia de estatus y no el acto en sí:

Al ano salaz, la negra alcantarilla por la que vertéis vuestro estiércol, porquería y cochambre: el demonio se expresa a través de él y por eso os demoráis en la inmundicia de la defecación y os entregáis sin pudor al vicio de la sodomía: pero no todo el mundo es así: afortunadamente todavía hay clases: y el Señor, en Su sabiduría infinita, ha dispuesto que las criaturas terrestres se alcen, en orden y proporción a sus méritos, de la vida animal y sus secreciones impuras: unos con el ojo nefando abierto sobre las miasmas de la zanja pública: otros depurándose poco a poco en un excusado pulcro y recoleto. (606)

En ese lenguaje cargado de ironía y crítica, el autor del texto nos lleva a que el acto sexual de la sodomía tan sólo es asociado con quienes utilizan la zanja pública, las clases sociales más bajas, las que no tienen poder económico ni aparentemente podrán alcanzar el éxito en la vida.

\footnotetext{
${ }^{47}$ El texto de Goytisolo habla principalmente desde la perspectiva de la religión católica ya que es la mayoritaria en España y la única aceptada durante la dictadura franquista.
} 
Hasta aquí esa interpretación del acto de defecar como base para establecer diferencia de clases. En la crítica se pueden encontrar otras interpretaciones. Ángel Sahuquillo dice: "La triada 1) analidad 2) evacuación o expulsión y 3) exilio y marginación que observamos en la obra de Goytisolo, ¿no será también una reacción contra la marginación y la expulsión producida por los poderes instituidos de España, de Cuba y de otros países?" (133). En el caso de España podría asociarse este planteamiento con la expulsión de los árabes y judíos tras la toma del último reino nazarí de Granada por los Reyes Católicos. En el caso de Cuba hay una clara referencia a la situación de marginalidad de los esclavos negros. Lo que sin duda encontramos en Juan sin tierra, es un acto de denuncia contra la marginación. Hay una solidaridad hacia todos aquellos grupos sociales que son apartados de la sociedad. En este punto, tenemos otra coincidencia con Preciado, que hace del ano un espacio de universalización; una forma de huir de un sistema binario de categorización social.

El modelo hegemónico basado en la heterosexualidad y el patriarcado necesita para su pervivencia y lógica de actuación y sanción, dar mayor importancia a los órganos sexuales "reproductores," pene y vagina, en un intento de justificar la reproducción como fin último de la relación sexual entre los seres humanos. Este sistema garantiza perpetuar un modelo social basado en el capitalismo. La única forma de neutralizar el poder de división y diferenciación social que tiene esta forma de organización económica es la de poner en evidencia sus deficiencias y la muestra explícita de los mecanismos de los que se dota el sistema para profundizar en esas diferencias. Goytisolo lo hace a lo largo de toda la novela. Algunos críticos como Andrés Zamora llegan a decir que "En Juan sin tierra se imputa a la civilización occidental el haber fundamentado sus sistemas de 
clasificación humana no tanto en las maneras de comer, como en las de cagar" (356). Tanto Preciado como Goytisolo abundan en la necesidad de establecer un sistema alternativo en la organización social que ayude a la reterritorialización y resignificación. Preciado lo hace estableciendo un nuevo órgano del cuerpo humano como punto de construcción y análisis del cuerpo biopolítico. Goytisolo lo hace mediante una denuncia de lo injusto de la diferencia cuando lo único que distingue a unos y a otros no tiene nada que ver con el cuerpo, sino con los espacios que se utilizan para realizar la función biológica principal de este órgano del cuerpo humano. Ambos intentan romper con esa idea que señala Guy Hocquenghem ${ }^{48}$ cuando dice que "the anus has no social position except sublimation" (96). Hocquenghem nos viene a decir que ha habido un empeño en hacer de esta parte del cuerpo humano algo sucio y rechazado por la sociedad. Sin embargo, en Juan sin tierra el ano y su función excretora tienen un fin reivindicativo. Los tres autores: (Hocquenghem, Preciado y Goytisolo) realizan un acto de rebelión con sus textos y un intento de hacer conscientes de las desigualdades que genera el sistema capitalista y la forma en que se establecen procesos para marginar a determinados colectivos sociales considerados abyectos. Así comenta Preciado:

Hocquenghem será no solamente uno de los inventores del "saber anal" y dinamizador de sus políticas sino también aquel que de manera más lúcida indicó las posibles trampas que acechaban al movimiento homosexual con la entrada en la esfera pública y la integración en las instituciones sociales hegemónicas (familia, escuela, ejército, museo, hospital). (161)

\footnotetext{
${ }^{48}$ El autor de Homosexual Desire es una de las referencias de Preciado precisamente por el carácter transgresor de su obra. El habla del concepto de texto terrorista y esta obra estaría entre ellos. Hay una confrontación entre el capitalismo y la homosexualidad. Como Preciado dice: "Es el primer diagnóstico crítico acerca de la relación entre el capitalismo y la heterosexualidad realizado por un marica que no oculta su condición de "escoria social" y "anormal" para empezar a hablar"(138). También no debemos olvidar que este libro es contemporáneo en el tiempo para Juan Goytisolo y él conocía también esta obra. Su lectura puede haber incidido en sus planteamientos.
} 
En Juan sin tierra hay todo un tratado sobre lo que la sociedad hace a partir del concepto de pareja reproductora. El narrador habla de esa forma de relación humana así: "Parejita Reproductora todas las naciones, sin distinción de ideologías ni credos, alimentan su mito, iglesias y gobiernos unánimemente la ensalzan, los diferentes medios de información se sirven de ella para fines de promoción y propaganda" (637). Ambos autores establecen ese paralelismo entre el modelo heterosexual y su relación con el modelo capitalista y las consecuencias que causa esta relación.

En esa denuncia del modelo hegemónico de masculinidad encontraremos también a otro autor y teórico, Néstor Perlongher, pensador argentino. ${ }^{49}$ Un elemento plenamente coincidente con Goytisolo es el concepto compartido con el teórico argentino es la idea de desterritorialización. Perlongher en una entrevista que forma parte de su libro Prosa plebeya dice sobre esta cuestión: "El exilio, aunque tenga sus lados dorados, desterritorializa y parece que no hay vuelta, se territorializa en la desterritorialización, un nomadismo de la fijeza" (17). Ese movimiento, ese nomadismo y sus consecuencias en palabras del narrador de Juan sin tierra significa lo siguiente: "el exilio te ha convertido en un ser distinto, que nada tiene que ver con el que conocieron: su ley ya no es tu ley: su fuero ya nos es tu fuero: nadie te espera en Ítaca" (634). Esa desterritorialización no se refiere tan sólo al abandono del país de origen, también se refiere a una nueva forma de ser, de comportarse, de vivir. El narrador de Juan sin tierra comenta así: "eres el rey de tu propio mundo y tu soberanía se extiende a todos los confines del desierto: vestido con

\footnotetext{
${ }^{49}$ Él bebe del pensamiento francés y aporta un punto de vista sobre la cuestión queer que le hace no sólo innovador, sino también precursor y anticipador de algunos planteamientos teóricos que hizo posteriormente la academia americana que es considerada la principal fuente de recursos en este campo de estudio. Epps hace una revisión de la importante aportación que hace este intelectual argentino a la teoría queer. Perlongher era también antropólogo e hizo su tesis doctoral sobre la situación de los michés en Brasil. Se trata de un texto clave para entender Perlongher; publicado en portugués y posteriormente en español y a partir del cual surgen gran parte de sus aportaciones teóricas.
} 
los harapos de fauna de origen, alimentándote de sus restos, acamparás en sus basureros y albañales mientras afilas cuidadosamente la navaja con la que un día cumplirás tu justicia" (634). En ese espacio donde el individuo se siente más anónimo por no ser del lugar en el que habita tras abandonar su tierra de origen. Adquiere una forma de ser que le va a plantear la posibilidad de reinventarse, de adquirir nuevas formas de comportamiento y de actitud ante la vida. Se puede conseguir llegar a ser otra persona. Este asunto se puede identificar con una nueva perspectiva que Preciado va a desarrollar en torno a la idea del exilio. Algo que va más allá de la cuestión de salir del país y que ella definió así:

La cuestión del exilio es una noción que me interesa profundamente, es decir, estar exiliado con respecto a tu propio género, tu propia sexualidad, estar exiliado con respecto a tu propia lengua....no hablar tu propia lengua porque tu lengua no es ninguna, mi relación con el castellano es una relación extraña porque en principio es mi lengua materna, pero ya casi no la hablo....Para mí, el exilio es constitutivo, ha formado parte de quien soy. (Betevé)

Por lo tanto, el exilio vivido por Goytisolo tiene también una plasmación en esta obra ya que muestra las consecuencias de ese exilio personal y sexual que vive a partir de la huida hacia otro lugar. Ese exilio provoca su divorcio, también le hace vivir abiertamente su homosexualidad y reconocer el amor profundo hacia su ex mujer, Monique Lange, a quien sigue considerando el amor de su vida. Goytisolo también tiene esa sensación de que su lengua materna ya no le pertenece y juega con sus palabras y también con la gramática.

Todo este relato implicará también unas consecuencias a la hora de conocer quienes leen las obras de Goytisolo. Esto vendrá determinado por el contenido de sus relatos. Sartre comentaba que: "Es la elección hecha por el autor de un aspecto del mundo 
lo que decide quién va a ser el lector y, recíprocamente, que el escritor, al elegir su lector, decide su tema”. (55) El hecho de que un autor decida hablar de un tema u otro en sus obras, va a determinar quiénes acabarán leyéndolas. Goytisolo al hablar del acto de defecar y la simbología que tiene el ano, se dirige a personas que se sientan identificadas con esa forma alternativa de comportamiento. En esta cuestión se ha establecido un paralelismo con el planteamiento teórico de Paul B. Preciado.

Ahora vamos a centrar este análisis en otra cuestión que también puede ayudarnos a conocer mejor una perspectiva sobre la existencia de formas alternativas de masculinidad. Para ello vamos a hablar del deseo, un asunto que aparece con fuerza en la obra de Goytisolo. En este tema va a coincidir con otro teórico, en este caso, con el autor y teórico queer argentino, Nestor Perlongher del que Epps comenta: "Lejos de ser una abstracción o una entelequia, el deseo para Perlongher, es el efecto de lugares, momentos, prácticas y personas específicas” (250). Al centrar nuestro análisis en esta cuestión del deseo vamos a resaltar el papel que desempeña el personaje de King-Kong a la hora de ejercer de gran símbolo del deseo en Juan sin tierra. Este personaje mítico es un gigante que controla, que incita y que tienta a la sociedad de forma continua. Un ser que se presenta de varias formas y que sufre una serie de transformaciones a lo largo del texto. Es tal la transformación que en un momento dado acabará siendo “Queen-Kong” (713), consecuencia de ese devenir del que nos habla el escritor argentino al mencionar el Antiedipo de Guattari y Deleuze. ${ }^{50} \mathrm{El}$ devenir del que hablamos antes es el que hace que un personaje que en la leyenda es un prototipo de masculinidad, pase a ser una mujer,

\footnotetext{
${ }^{50}$ Perlonguer dice en El sexo de las locas: "Guattari, el coautor del Antiedipo, habla de un devenir mujer que abre a todos los demás devenires. Siguiéndolo podemos pensar la homo o la heterosexualidad” (33).El monstruo King-Kong acaba siendo mujer también, es decir, cualquier forma es posible.
} 
cualquier ser vivo puede experimentar cambios de ese tipo. Puede adquirir la forma de la incitación a llegar a ser esa pareja socialmente aceptada por el patriarcado y el capitalismo donde como cuenta el narrador:

el sólido materialismo de King-Kong les perseguirá adonde quieran que vayan con la evidencia palmaria de sus contundentes razones: y el viaje nupcial a París, aconsejado por los mejores doctores, agravará todavía su estado mental: la tour Eiffel, el obelisco de la Concorde mantendrán vivo el recuerdo de la visión lancinante. (644)

Aquí King-Kong adquiere la forma de ese capitalismo feroz que intenta provocar una decisión, la de llegar a ser la pareja que garantice la reproducción del sistema mediante la reproducción sexual. Ese mismo personaje adquiere otras caras, otras formas. Es lo que ocurre cuando es mostrado como representación del deseo homosexual:

pero la remota soledad de la cumbre te brinda compensaciones secretas y tu locura aparente se justifica: el diámetro y longitud del fuste de la columna, la pulida superficie cilíndrica que te sirve de apoyo bastarían para colmar por sí solos los más extravagantes sueños de dicha de la devota grey de King-Kong. (658)

El deseo adquiere varias formas en el cuerpo de ese animal y puede encontrarse en varios lugares a la vez y tener incidencia en distintas personas.

Volviendo a la idea del devenir del deseo de la que habla Perlongher, recordamos que se trata de un concepto que lo desarrolla tras haber leído a Deleuze y Guattari y como consecuencia de su experiencia como antropólogo urbano en Brasil donde hico un estudio sobre los miché. ${ }^{51}$ Su punto de vista como antropólogo permite incorporar una visión de lo que significa el deseo, desde el análisis cualitativo. Christian Ferrer y Osvaldo Baigorria recogen en el prólogo de Prosas plebeyas que "el deseo-y no lo gay-fue el punto de anclaje de Perlongher para pensar lo político, en una época en que se

\footnotetext{
${ }^{51}$,Jóvenes de clase social obrera que se dedicaban a la prostitución en Sao Paulo.
} 
proclamaba abiertamente que ‘todo lo personal es político’ pero en la cual los homosexuales "no existían"" (7). Estas afirmaciones pretenden salirse de un campo político y social que únicamente establece posibilidades binarias. Perlongher habla de la noción del deseo como algo líquido, algo que permite moverse de un tipo de deseo a otro sin que exista ninguna limitación. Este punto de vista permite interpretar algo que también se da en la vida y por supuesto, en la obra de Juan Goytisolo. En Juan sin tierra estamos ante personajes que actúan rigiéndose por el deseo y teniendo distintos tipos de experiencias sexuales y de relaciones a lo largo de su vida y no por ello han de ser censuradas o castigadas. En una entrevista que le hacen a Perlongher sobre su obra, él habla de lo que él considera el devenir: "Ser es devenir, devenir negro, devenir mujer, devenir loca, devenir niño" (21). Él hace una propuesta que huye de las categorizaciones binarias. Propone un sistema en que tengan cabida muchas más posibilidades que las que ofrece el sistema dual. Se trata de huir del rígido sistema heteronormativo impuesto sobre los biocuerpos ${ }^{52}$ para llegar a la inclusión de todas las posibilidades de comportamiento sexual y de relaciones sin que el sexo sea el núcleo sobre el que se haga esa categorización. Perlongher nos dice: “Si el deseo se fuga, construyendo su propio plano de consistencia, es en el plano de los cuerpos, en el estado del cuerpo del socius, que habrán de verse molecularmente las vicisitudes de su fuga" (Matan 38). Ese concepto del socius $^{53}$ viene del texto del Antiedipo de Deleuze y Guattari. En Juan sin tierra podemos identificar uno de estos momentos en que hay un impulso que produce una fuga cuando se está observando la forma en que los esclavos tienen sexo en sus estancias

\footnotetext{
${ }^{52}$ Los cuerpos son asociados con el sexo con el que nacen, pero esto no quiere decir que a partir de eso, se tenga tan sólo una opción sexual, se puede dar un cambio a lo largo de la existencia de ese cuerpo.

${ }^{53}$ Deleuze y Guattari en su Antiedipo lo definen así; "Its one purpose is to point out the fact that the forms of social production, like those of desiring-production, involve an unengendered nonproductive attitude, an element of antiproduction coupled with the process, a full body that functions as a socius.
} 
dentro de la finca que supuestamente pertenecía al abuelo del protagonista de la novela: "no es siquiera la cópula normal, el acto creador que excusan los cánones: la propagación de la especie en un fin noble, aun tratándose de hijos oscuros y cuitados" (610). Más adelante el narrador continúa dando detalles explícitos de cómo se manifiesta esta máquina de deseo en el caso de los esclavos negros cuando dice: "obligáis a voltearse a las negras y buscáis sus partes traseras: abriendo túneles corruptos en su negrura infame: y aún peor: exigiendo que se arrodillen delante, acercando la caña quemada a los belfos e introduciéndola dentro" (610-11). La ruptura política que lleva a cabo este texto es la de mostrar cómo es la sexualidad en estado puro de deseo, fuera de ese discurso que limita el ser sexual a un fin meramente reproductivo, sin que haya opción a la búsqueda del placer sin más. De hecho, siguiendo con la forma en que los esclavos negros dejan libre su forma de deseo sexual el narrador dice: "Os habíamos quitado las hembras para evitaros la ocasión de pecar y aumentar de paso vuestro rendimiento y con pravedad obstinada, habéis persistido en el vicio: vuestra maldad es demasiado profunda y sin duda no tiene remedio" (608). Ante la mirada perpleja de la hija del amo, ésta ve cómo los esclavos mantienen relaciones sexuales también entre personas del mismo sexo. Se trata de un momento en que se asiste a una de las múltiples formas que puede adoptar el deseo en esa deriva de la que nos habla Perlongher. Como señala Epps: "Playing with its own signifying elements, Juan sin tierra imagines a freedom that depends, as chance would have it, on the law of desire" (138).

Es precisamente el continuo movimiento provocado por el deseo algo que caracteriza a esta trilogía y especialmente Juan sin tierra. La propia evolución que el narrador va teniendo a lo largo de las tres novelas viene a justificar una actitud que 
defiende un marco en el que algo tan universal como el deseo marca los ritmos de comportamiento de las personas, dando así la posibilidad de cambios a lo largo del tiempo sin recibir censura social por ello. Perlongher nos ayuda a entender también esa posición de Goytisolo ante la cuestión del deseo. En Juan sin tierra, podemos encontrar esa "deriva de los sujetos" a la que se refiere el autor y teórico argentino cuando nos habla de la cuestión del territorio donde se producen estas formas distintas de buscar el placer:

El propio territorio donde estos encuentros se consuman configura una especie de tierra de nadie, ocupada por los enseres móviles de las diversas tribus marginales. Putas, michés, travestis, malandros, malucos y todas las variantes del lumpesinado, disputando áreas de influencia o de alianza, con una presencia constante: la policía, cuya relación de exterioridad jurídica respecto de ese mundo "sub" se relaja en una maraña de complicidades y venganzas. (42)

Lo que Perlongher plantea aquí es que los espacios donde es posible liberar cualquier forma de deseo, van a estar limitados a lugares marginales, donde todos los sujetos que viven fuera de los límites del cuerpo sexual políticamente admitido, podrán sentirse libres de llevar a cabo sus deseos. Son espacios que en algún momento van a dejarse fuera del control exhaustivo de la justicia o del control policial.

De manera similar, Goytisolo presenta un lugar donde se producen los encuentros fortuitos: "Cuando la noche clausura las actividades productivas, discretamente razonables de la atareada ciudad, los adoradores del bicho emergen de su habitual letargo diurno y, tras atisbar con cautela las aceras desiertas, discurren furtivos por las zonas solitarias y umbrosas, sin atender al crepuscular derroche de propaganda de los adversarios de los ofidios"(646-47). ${ }^{54}$ coloquial.

${ }^{54} \mathrm{Al}$ mencionar el bicho se refiere a la forma puertorriqueña de referirse al pene dentro de la jerga 
Es interesante como el texto sigue describiendo a quienes forman parte de esta especie de danza urbana, "en esa red de flujos" (Perlongher 46) cuando el narrador de Juan sin tierra nos sigue relatando:

La cordura envidiosa de los paterfamilias no hace mella en su ánimo, y cortando en zigzag por las esquinas del miedo a fin de despistar a los eventuales perseguidores, explorarán los lugares sombríos y húmedos en que el odiado y temido animal habitualmente se encorva: las cavernas desconchadas, musgosas, donde la subterránea acción del agua inventa goteras, cascadas y estalactitas, pobremente iluminadas por una bombilla enferma, del tipo de las que suelen alumbrar los calabozos y jaulas en los sótanos de las comisarías. (647)

Llama la atención la mención a la posible presencia de la policía como forma de control sobre lo prohibido. El hecho de la oscuridad y el deterioro físico de los espacios es otra de las cuestiones que nos gustaría resaltar de esta descripción:

Saboreando su recia virtud con el gesto solemne de quienes cierran los ojos de arrobo cuando el mágico deposita el candoroso talismán en su lengua: Arrodillados también, si no en el suelo, en tosco y humilde reclinatorio: inmersos en la beatitud de su sublime pero incomunicable experiencia: sin olvidar, después, tampoco, los consabidos ejercicios de acción de gracias: los actos de deseo, ofrecimiento y humildad que los manuales de preparación aconsejan: mas el frenesí de la noche apremia, y abandonando el recogimiento y soledad de la cripta, proseguirán con diligencia incansable el periplo aleatorio de sus visitas. (647)

El deseo se manifiesta en los cuerpos y los espacios demarcan un territorio donde es posible liberar esa forma de deseo. Quienes están allí tienen conciencia del peligro que corren si son vigilados, pero la necesidad que sienten de disfrutar del placer que encuentran allí, hace que pierdan ese temor. Esta escena perfectamente podría llevarnos a cualquiera de las que el autor argentino pudo recoger en su tesis sobre los michés en Brasil. Ese espacio al que se refiere Perlongher puede darse en cualquier lugar del mundo. En Juan sin tierra, donde se producen los encuentros sexuales esporádicos que se 
describen, tiene un carácter universal, Goytisolo no establece en el texto un punto geográfico concreto, podría tratarse de cualquier lugar del planeta.

A lo largo de la novela podemos ver cómo se representan muchas escenas de lo que podríamos denominar un submundo, un lugar donde ocurren cosas fuera de la heteronormatividad. Se usan símbolos como la aparición de ofidios que son animales que suelen vivir bajo la superficie de la tierra o escondidos en el subsuelo. Se trata de todo un símbolo que trata de establecer una diferencia entre los que viven arriba y los que viven en abajo; o mejor dicho, quienes viven en la parte oscura, oculta. Se establece así una diferencia social en función de cómo es vivido ese deseo. Es una manera alternativa que no es aceptada y requiere de espacios ocultos para que no se ponga en peligro esa organización social basada en la heterosexualidad y la reproducción como motor de la economía capitalista. Esas formas alternativas de masculinidad tienen cabida en estos espacios. La transformación del cuerpo es una constante reseñada por el narrador en la novela. Nos dice: "tu cuerpo ha adquirido la reptante flexibilidad del ofidio y la mera visión de la enemiga fauna suscita en tu fuero interno imágenes suntuosas de violencia verbal" (649). Hay una aceptación del riesgo de ataque al que uno se expone por tener un comportamiento sexual que no es aceptado socialmente. El riesgo que conlleva la disensión y el vencer los límites de lo aceptado socialmente es evidente, así lo mantenía también Perlongher: "O quizá, se trate en las poblaciones afectadas de un inestable equilibrio entre la potencia del deseo y el miedo de la muerte" (44). El personaje principal de la novela de Goytisolo nos muestra a alguien que se siente liberado, sin temor ante esas posibles amenazas; a alguien que hará de ese deseo su motor de actuación 
y no dejará que sus miedos le limiten en ningún momento a la hora de hacer lo que le gusta.

A modo de conclusión podemos decir que la obra Juan sin tierra de Juan Goytisolo anticipa y muestra ejemplos que tienen conexión directa con parte de las teorías queer hispanoamericanas, tanto con Paul B. Preciado como con el argentino Néstor Perlongher. El primero hace un claro intento de cambiar la organización económica y social a partir de la focalización en el ano como parte del cuerpo que permite estructurar una visión de la realidad en la que el cuerpo no sea motivo de diferenciación de género y permita que existan formas alternativas de definir y explicar el comportamiento social y sexual. Hemos podido comprobar cómo, Goytisolo, recoge insistentemente su visión sobre la importancia de este órgano, aunque se centra especialmente en la función de la defecación más que en el órgano en sí. Con ello pretende mostrar una crítica profunda a la forma de organización social y la exclusión por razones de raza y clase social. Esta novela podría también considerarse un texto terrorista desde el punto de vista de Paul Beatriz Preciado ya que intenta establecer una conexión entre el sistema capitalista y el poder que ejerce sobre las personas la sexualidad. Se trata también de un manifiesto en el que la palabra es la principal arma. La palabra sirvió para destruir y la palabra sirve para reconstruir. Es esa situación de inauguración de un nuevo momento la que nos permite visibilizar todo un proyecto en el que se plantean sin temor las carencias de un modelo social que genera injusticia y desigualdad. Podríamos decir que en la novela de Goytisolo tenemos la muestra de esas deficiencias y serán las teorías de Preciado y Perlongher las que nos permitan dar sentido a ese posible proyecto de futuro que podría deducirse del texto de Goytisolo. Cuando España inicia un momento de 
cambio político y un proceso de transición a la democracia, en la obra de Juan Goytisolo, podemos conocer también una nueva fase en la personalidad y todo un proyecto de futuro que se desvincula del pasado más dañino.

Ese espacio donde los homosexuales pueden dar rienda suelta a su forma de deseo también aparece en la novela de Vargas Llosa y lo hace a través de la voz del protagonista Roger Casement. Lo paradójico de esta novela se encuentra en que quien que nos habla de esas personas que fueron objeto de abuso por sus colonizadores, no es más que alguien que acabará también siendo víctima de ese aparato censor que es la metrópoli (se pone en marcha una acción implacable al descubrirse públicamente su homosexualidad junto a la traición que hace a la corona). El nacionalismo es una vía de liberación en su inicio, aunque con el paso del tiempo acaba reproduciendo un aparato de control que hace que se identifiquen quiénes pueden y quiénes no son considerados miembros de ese sistema. En la novela de Vargas Llosa podríamos decir que conocemos esa etapa inicial cuando se habla del movimiento que quiere la independencia de Irlanda del Norte; sin embargo, en la novela de Goytisolo encontramos una crítica a esa nación histórica que ejerce todo su poder político y de control para destrozar todo aquello que le es molesto. La sociedad se dota de herramientas de control que intentan por un lado generar sujetos que se asemejen a su modelo de masculinidad hegemónico. En ambas novelas, la cuestión de la sexualidad tiene un peso importante. El ser homosexual se considera una conducta disruptiva. Como dice Paul Beatriz Preciado "la homosexualidad es una ficción política" que a partir del siglo XIX se derivó al campo de la medicina para catalogarla como enfermedad a tratar. La realidad actual es muy distinta a la que encontramos en la novela de Goytisolo. 
En ambas novelas tenemos ejemplos de masculinidades alternativas que acaban siendo rechazadas y eliminadas por el sistema. En el caso del texto de Vargas Llosa, por su doble traición a la nación. Es posible que el liderazgo de Casement antes o después hubiera sido atacado por su homosexualidad. No hay un límite entre la vida pública y la privada; la sexualidad de las personas es algo que también controla el sistema político y sancionador de la nación, sobre todo para que no se rompa esa relación entre productividad, economía y sexualidad. Es en la novela de Goytisolo donde podemos comprobar la lucha contra esos principios y el carácter de ataque al sistema que adquiere su escritura. Ambos autores utilizan la escritura como una "tecnología de inscripción" (Preciado) y en el acto de escribir, lo que se está haciendo es crear otras formas de subjetividad que muestren una alternativa al modelo que propone la sociedad patriarcal. 


\section{CONCLUSIONES}

En este trabajo de tesis hemos podido comprobar la relación existente entre términos que aparentemente pueden parecer tan dispares como la religión, la economía, la sexualidad, la nación o el género. Sin embargo, no es así; todo ello está interrelacionado cuando se trata de hablar del patriarcado. Este es un modelo de organización social que se dota de varios instrumentos para poder garantizar su supervivencia a lo largo de los años. Para este fin, se establece un modelo de masculinidad que será el que garantice esta continuidad. Tanto Juan Goytisolo como Mario Vargas Llosa reflejan en sus respectivos trabajos, tanto la relación existente entre todos los elementos mencionados anteriormente, como las consecuencias que esta masculinidad hegemónica provoca en una sociedad que no es de una sola forma, sino que es diversa.

. Como dice Paul Beatriz Preciado, la escritura es una tecnología de producción de género. A través de la escritura se están desarrollando modelos que nos muestran cómo funciona la sociedad, cómo son las reglas del cuerpo político y cuáles son los elementos de control para que perviva un modelo de nación que será claramente de inspiración capitalista y patriarcal. Tanto Juan Goytisolo como Vargas Llosa hablan en sus obras de ese modelo de nación opresora, controladora y homogeneizadora. No obstante, la gran novedad del trabajo de ambos reside en el hecho de que nos muestran también los efectos que produce esta tarea de control social en personajes que no son capaces de adaptarse a esos sistemas de vigilancia, y que incluso, en algún caso, se enfrentan a ese sistema controlador, de forma abierta. En otros casos, son víctimas del mismo y llegan incluso a desaparecer. En La ciudad y los perros esto último es lo que le ocurre a Ricardo Arana, el Esclavo. Este personaje acaba muriendo porque su forma de 
ejercer su masculinidad produce rechazo por parte de sus compañeros al entender que no es útil para que ese patriarcado siga en pie. En el caso de la obra de Juan Goytisolo, es el mismo autor quien lucha contra todo ese aparato; lo hace mediante la escritura de varias de sus novelas, pero de una forma más violenta en Reivindicación, donde destroza los fundamentos de un sistema de control social y político que, según la opinión del autor, ha eliminado cualquier posibilidad de coexistencia de las distintas realidades culturales, sociales y religiosas que en un momento de la historia, se dieron en la Península.

Tanto en Juan Goytisolo como en Vargas Llosa, sus obras autobiográficas son fundamentales para la comprensión de su obra narrativa. Hay un traspaso continuo de personajes y hechos que se mueven alternativamente del género biográfico al género de ficción En algunos casos serán ellos mismos quienes aparecen en sus novelas de ficción; en otros casos, son personajes inventados que se nutren de experiencias de vida que tuvieron los autores de las obras. Si leemos La Tía Julia y el escribidor, es fácil identificar a Vargas Llosa en algún momento a partir del seguimiento del personaje de varguitas; de igual forma encontraremos a un Álvaro Mendiola en la trilogía de Goytisolo que nos va a llevar directamente a las vivencias personales del escritor español a lo largo de las distintas etapas de su vida. Esta conexión ayudará a entender mejor el compromiso social que ambos practican y cómo su vivencia personal será una de sus fuentes de inspiración más importantes.

Las naciones, como comunidades imaginarias desde la perspectiva de Benedict Anderson, tienen siempre un componente de género que será fundamental para poder garantizar la pervivencia de un modelo patriarcal que haga que el poder de la masculinidad hegemónica se mantenga. No se puede, por tanto, hablar de nación sin 
hablar también de género. La nación está formada por cuerpos sexuados que tienen una función simbólica que ayuda a la ciudadanía a identificarse en función de su sexo con el rol que les será asignado en sus respectivas comunidades. La homosexualidad pasa a ser a partir del siglo XIX una enfermedad que ha de ser tratada. En muchos casos, la cura consistió en la esterilización y la anulación de cualquier posibilidad de continuidad con el placer sexual de las personas condenadas por esta práctica sexual. Se niega así la posibilidad de que la sexualidad sea algo que tenga como objetivo el deseo. El sistema capitalista pretende que el fin fundamental de las relaciones sexuales sea el de la reproducción. A partir del siglo XIX el estado se incorpora a ese control de la sexualidad y une así su poder al que hasta ese momento había ejercido la religión. En el caso de Goytisolo, encontraremos en su obra Juan sin tierra, una forma alternativa de mostrar la masculinidad y a través de ella se utilizarán símbolos que nos ayudan a conocer una vía alternativa de vivir la sexualidad. De igual forma, Vargas Llosa hará de la sexualidad como deseo, parte de la trama en alguna de sus novelas. Un de ellas es La ciudad y los perros y El sueño del celta.

Es importante tener en cuenta que gran parte del marco teórico de esta tesis proviene de un corpus que ha permitido ir más allá de la justificación del modelo social hegemónico. Se han utilizado para el análisis de la obra de Goytisolo y Vargas Llosa, teorías que ofrecen un punto de vista más abierto y alternativo. Tenemos entre ellas a la idea de construcción continua de la democracia tan derridiana, o la teoría del compromiso social que han de ejercer los escritores que impulsó Sartre, así como las teorías queer, que hacen de lo abyecto y marginal la base de su pensamiento. Todo ello nos ha ayudado a poder incorporar visiones alternativas que pretenden mostrar hasta qué punto hay otras 
formas de ejercer la masculinidad y a conocer en profundidad la experiencia personal de personajes de la ficción en las obras de Goytisolo y Vargas Llosa. Ambos autores padecieron personalmente lo que significa ir en contra de este modelo hegemónico de masculinidad. Goytisolo lo hizo porque declaró y ejerció públicamente su homosexualidad y en el caso de Vargas Llosa, porque tuvo que luchar contra su propio padre para defender el deseo de hacer de la escritura su profesión, cuando tanto progenitor como parte de la sociedad de su época de infancia y adolescencia, consideraban que este no era un oficio para hombres.

La idea de la libertad como fin máximo al que ha de acceder el ser humano, independientemente de en qué lugar se encuentre, es algo compartido por Goytisolo y Vargas Llosa. Sus obras son espacios donde se ejerce la libertad de mostrar abiertamente una crítica a sus respectivas naciones de origen y también a todo aquello que impida ejercer ese derecho a cualquier persona. Puede que la deriva personal de ambos haya sido muy distinta en lo personal, pero en lo que a su obra se refiere, los dos autores hacen de la literatura un espacio para la disensión y la crítica. En ocasiones atacarán a determinados mitos para aferrarse a otros. De hecho, en el caso de Goytisolo podemos ver que abraza el mito de Oriente, como lugar donde todo es posible. Esto es algo propio de muchos autores occidentales, aun así, no deja de ser una oportunidad para mostrar realidades alternativas que son muy útiles para entender que no todo es de una sólo forma posible. 


\section{OBRAS CITADAS}

Adams, Rachel and David Savran. The Masculinity Studies Reader. Malden:

Blackwell Publishing, 2002. Impreso

Anderson, Eric. Inclusive Masculinity. The Changing Nature of Masculinities. New York: Routledge, 2009. Impreso.

Anderson, Benedict. Imagined Communities: Reflections on the Origin and Spread of the Nationalism. London: Verso, 1991. Impreso.

Anderson, Linda. Autobiography. New York. Routledge.2001. Impreso

Arnold H, John Ed. What is Masculinity? Historical Dynamics from Antiquity to the Contemporary World. London: Palgrave McMillan, 2011. Impreso.

Alsop, Rachel, Annette Fitzsimons, y Kathleen Lennon. Theorizing Gender. Cambridge: Polity P, 2003. Impreso.

Barthe, Roland. Image. Music. Text. New York: Hill and Wang, 1977. Impreso.

Berco, Cristian. Sexual Hierarchies, Public Status. Men, Sodomy and Society in Spain's Golden Age. Toronto: U of Toronto P, 2007. Impreso.

Bhabha, Homi. The Location of Culture. New York: Routledge. 2006. Impreso

Blazina, Chris. The Cultural Myth of Masculinity. Westport: Praeger, 2003. Impreso.

Boone, Joseph Allen. "Vacation cruise; or the homoerotics of orientalism". PMLA 110.1 (1995)pp. 89-107. Impreso.

Brittan, Arthur. Masculinity and Power. Oxford: Basil Blackwell, 1989. Impreso.

Braudy, Leo. From Chivalry to Terrorism. New York: Alfred E. Knopf, 2003. Impreso.

Carrigan, Tim, Bob Connell and John Lee. "Toward a New Sociology of Masculinity" The Masculinity Studies Reader. Eds. Adams, Rachel, y David Savran. Malden: Blackwell Publishing, 2002. Impreso.

Cibreiro, Estela. "Reivindicación del conde don Julián y la trilogía de Juan Goytisolo: la dialéctica entre el individuo, la historia y el discurso literario" Hispanic Journal vol.15, num 1, Spring 1994, pp. 7-20. Impreso.

Carrillo, Santiago. Eurocomunism and the State. London: Lawrence and Whishart, 1976. Impreso 
Castañeda, Belén S. "Mario Vargas Llosa: El novelista como crítico". Hispanic Review, Vol. 58, No. 3 (Summer, 1990), pp. 347-359. Impreso.

Corral, Wilfrido H. "La comunidad imaginaria de Fuentes, Goytisolo y Vargas Llosa". Estudios Literatura española de los siglos XIX y XX: homenaje a Juan María Díez Taboada. (1988): 839-844. Impreso.

Coates, Jennifer. Men Talk. Stories in the Making of Masculinities. Malden: Blackwell Publishing, 2003. Impreso.

Cohler, Bertram. Sixty Years of Gay Autobiography. Wisconsin: The Univesity of Wisconsin P. 2007. Impreso

Colebroo, Claire. "Literature". Reynolds, Jack y Jonathan Roffe eds Understanding Derrida. London: Continuum, 2004. Impreso.

Connell, R.W. Masculinities. Los Angeles: California UP, 1995. Impreso.

Connell, R.W., D.J. Ashenden, S. Kessler, and G.W. Dowset. Making the Difference. Schools, Families and Social Division. Sidney: George Allen and Unwin, 1982. Impreso.

Corral, Wilfrido H. "La comunidad imaginaria de Fuentes, Goytisolo y Vargas Llosa". Estudios Literatura española de los siglos XIX y XX: homenaje a Juan María Díez Taboada. (1988): 839-844. Impreso.

Crompton, Louis. "Male love and Islamic Law in Arab Spain". Murray, Stephen y Will Roscoe. Islamic Homosexualities. Culture, History and Literature. New York: New York UP. 1997. Impreso.

Chambers, Iain. Mediterranean Crossings: The Politics of an Interrupted Modernity. Durham: Duke University Press, 2008. Print.

Champagne, Roland A. Jacques Derrida. New York: Twayne Publishers, 1995. Impreso.

Chodorow, Nancy. The Reproduction of Mothering. Psychoanalysis and the Sociology of Gender. Los Angeles: California UP, 1978. Impreso.

Dainotto, Roberto M. Europe (in theory).Durham: Duke UP, 2007. Impreso.

Deleuze, Gilles y Felix Guattari. AntiOedipus: Capitalism and Schizophrenia. Minneapolis:University of Minnesota P. 183. Impreso. 
Dravasa, Mayder. The Boom in Barcelona. Literary Modernism in Spanish and Spanish American Fiction (1550-1974). New York: Peter Lang, 2005. Impreso.

Duncan, Cynthia. "The Splintered Mirror: Male Subjectivity in Crisis in Los cachorros". Hernández de López, Ana María Ed. Maria Vargas Llosa: Opera Omnia. Madrid: Pliegos, 1994, Impreso.

During, Simon. "Literature. Nationalism's other? The case of Revision" Narration and nation Ed. Bhabha, Homi London: Routledge. 1990. 150-173 Impreso.

Ellis, Robert. "The Inscription of Masculinity and Whiteness in the Autobiography of Mario Vargas Llosa". Bulletin of Latin American Research 17.2 (1998): 223-36. Impreso.

----- $\quad$ "A Passage To The Self: Homoerotic Orientalism And Hispanic Life-Writing." Revista Canadiense De Estudios Hispánicos 30.1 (2005): 75-87. Impreso.

Epps, Brian."Retos y riesgos, pautas y promesas de la teoría queer." Debate feminista num. 36 2007, pp. 219-272. Impreso.

----- Significant Violence. Oppresion and Resistance in the Narratives of Juan Goytisolo, 1970-1990. Oxford: Oxford UP, 1996. Impreso.

"Retos y riesgos, pautas y promesas de la teoría queer" Debate feminista num. 36 2007, pp. 219-272. Impreso.

"Entrevista a Paul B. Preciado - Terrícoles I betevé" Youtube uploaded by Betevé. 7 Julio del 2018, https://youtu.be/04Uibmsg0zc

Fanon, Frantz. Black skin, white masks. Grove press, 2008. Impreso.

The wretched of the earth. Vol. 149. Grove Press, 1965. Impreso.

Ferré, Juan Francisco: “Autobiografía y (Des)Figuración en la obra de Juan Goytisolo". INTI, Revista de literatura hispánica. No. 55/56 (PRIMAVERA 2002 - OTOÑO 2002), pp. 47- 76. Impreso.

Foster, David W. Gay and Lesbian Themes in Latin American Writing. Austin: U of. Texas P, 1991. Impreso.

Foucault, Michel. Discipline and Punish. The Birth of the Prison. New York: Vintage Books, 1995. Impreso.

---. Historia de la sexualidad.1 La voluntad de saber. Madrid: Siglo XXI, 1980. Impreso. 
----- "Friendship as a Way of Life". Foucault live: collective interviews 1961-1984. Ed. S. Lotringer. New York: Semiotexte. Impreso.

Francina Islas Villanueva. Discurso de Juan Goytisolo Premio Cervantes 2014.YouTube: https://www.youtube.com/watch?v=gO8uivbjkqY 2015.

García, Sylma. "Del Dolor Al Júbilo En La España De Las Tres Castas: Diálogo Entre Juan Goytisolo Y Luce López-Baralt." Torre: Revista De La Universidad De Puerto Rico 13.47 (2008): 27-53. Impreso.

Goytisolo, Juan. “Juan sin tierra” Juan Goytisolo novelas (1966-1982) Barcelona: Galaxia-Gutenberg. 2005. Impreso.

-------La triada del mal. Barcelona: Modernos y clásicos de El Aleph. 2004. Impreso.

------- "Entrevista a Jean-Paul Sartre". Obras completas VI. Juan Goytisolo. Ensayos Literarios (1967-1999). Barcelona: Galaxia Gutenberg, 2007. Impreso.

------ Carajicomedia. Barcelona: Seix Barral. (2000). Impreso.

----- Coto vedado. Barcelona: Seix Barral, 1985. Impreso.

----- Ella, elle. Barcelona: Sirpus, 2010. Impreso.

----- "Elogio en el desacuerdo". El País. 26 noviembre (2004). Digital

----- En los reinos de taifas. Madrid: Alianza Editorial (2015). Edición Kindle.

---- "Señas de identidad" Juan Goytisolo. Novelas (1966-1982) Barcelona: GalaxiaGutenberg. 2005.

Goytisolo, Juan, and Linda G. Levine. Reivindicación Del Conde Don Julián. Madrid: Cátedra, 1985. Impreso.

Goytisolo, Juan, and Janet Pérez. "From Count Julian To Makbara: A Possible Orientalist Reading." The Review Of Contemporary Fiction 4.2 (1984): 109-119. Impreso.

Hocquenghem, Guy, and Daniella Dangoor. Homosexual Desire. Durham: Duke University Press, 1993. Impreso.

Higate, Paul R. Military Masculinities. Identity and the State. London: Praeger, 2003. Impreso. 
Hutcheon, Linda. A Poetics of Postmodernism. History, Theory, Fiction. New York: Routledge, 1988. Impreso.

Hocquenghem, Guy, and Daniella Dangoor. Homosexual Desire. Durham: Duke University Press, 1993. Impreso.

Jencks, Charles. What is Post Modernism?. London: Academy Editions, 1986. Impreso.

Jordan, Mark D. The invention of Sodomy in Christian Theology. Chicago: The U of Chicago P, 1997. Impreso.

Jorklund, Diane. Interpretation the Self. Two Hundred Years of American Autobiography. Chicago: University of Chicago P. 1998. Impreso.

“Juan Goytisolo (medineando)”. Imprecindibles. TVE. 2015. Televisión http://www.rtve.es/alacarta/videos/imprescindibles/imprescindibles-juangoytisolo-medineando/3188396/

Kirkpatrick, Susan. “The ideology of Costumbrismo”. Ideologies and Literature 1 (1978): 28-44. Impreso.

Koo, Pedro G. "Masculinidad en crisis: Representación masculina en cuatro novelas Latinoamericanas". Dissertation Abstracts International, Section A: The Humanities and Social Sciences (DAIA). 64.3 (2003): 924. Impreso.

“La filósofa Beatriz Preciado". Pienso, luego existo. RTVE. 13 Julio 2013, http://www.rtve.es/television/20130719/filosofa-beatrizpreciado/719062.shtml\#kmnts

Labanyi, Jo. Myth and History in the Contemporary Spanish Novel. Cambridge [England: Cambridge University Press, 1989. Impreso.

"Relocating Difference: Cultural History and Modernity in Late NineteenthCentury Spain”. Ed. Epps Brad y Luis Fernández Cifuentes. Spain Beyond Spain. Modernity, Literary History and National Identity. Lewisburg: Bucknell UP 2005. Impreso.

Lange, Monique. Trad. José Martín Arancibia. Las casetas de baño. Barcelona: Seix Barral (1983). Impreso.

Laskier Martin, Adrianne. An Erotic Philology of Golden Age Spain. Nashville: Vanderbilt UP, 2008. Impreso.

Lejeune, Philippe. On Autobiography. Minneapolis: U of Minnesota P, 1989. Impreso. 
Márquez Rodríguez, Alexis. "El sueño del celta de Mario Vargas Llosa” INTI. Revista de literatura hispánica. 71.72 (2010) 309-314. Impreso.

Martin-Márquez, Susan. Disorientations: Spanish Colonialism in Africa and the Performance of Identity. New Haven: Yale University Press, 2008. Impreso.

Mauro, Walter and Elena Clementeli. Los escritores frente al poder. Barcelona: Caralt, 1975. Impreso.

McClennen, Sophia A. The Dialectics of Exile : Nation, Time, Language, and Space in Hispanic Literatures. West Lafayette: Purdue UP, 2004. Impreso.

Molloy, Silvia. At Face of Value: Autobiographical writing in Spanish America . Cambridge: Cambridge UP. 1991. Impreso.

Mosse, George L. Nationalism and Sexuality. New York: Howard Fertig, Inc., 1985. Impreso.

Morcillo, Aurora. The Seduction of Modern Spain. The Female Body and the Francoist Body Politics. Cranbury: Rosemont Publishing and Printing Corp., 2010. Impreso.

---- “The Orient Within. Women in between under Francoism” Ed. Sadiqui Fátima y Moha Ennaji. Women in the Middle East and North Africa. New York: Routledge. Impreso.

Oviedo, José Miguel. "Vargas Llosa entre Sartre y Camus". Antípodas 8-9 (1996): 183193. Impreso.

------ Mario Vargas Llosa. La invención de la realidad. Barcelona: Barral, 1977. Impreso.

---- "La escisión total de Juan Goytisolo. Hacia un encuentro con lo hispanoamericano". Revista iberoamericana 52.95, (1976): 190-200. Impreso.

Pérez-Sánchez, Gema. Queer Transitions in Contemporary Spanish Culture: From Franco to La Movida. New York: State University of New York Press, 2007. Impreso.

Perlongher, Néstor. Prosa plebeya: ensayos, 1980-1992. Ediciones Colihue SRL, 1997. Impreso.

Prieto, Celia . Historia y novela: poética de la novela histórica. Pamplona: Ediciones de la Universidad de Navarra, 1998. Impreso.

Preciado, Beatriz. "Terror anal" HOCQUENGHEM, Guy. El deseo homosexual. Barcelona: Melusina , 2009. Impreso. 
Manifiesto contra-sexual. Madrid: Opera prima. 2002. Impreso.

Reeser, Todd W. Masculinities in Theory. An Introduction. Oxford: Wiley-Blackwell, 2010. Impreso.

Roy C Boland and Inger Enkvist."'Introduction. The specular narratives of Carlos Fuentes, Juan Goytisolo and Mario Vargas LLosa" Antípodas 8-9 (1996): 7-9. Impreso.

Said, Edward W. Orientalism. New York:Vintage Books, 1979. Impreso.

Orientalismo. Barcelona: Debolsillo. 2008. Impreso.

Sahuquillo, Angel. "El exilio, lo anal y la identidad poética en" Juan sin tierra". Specular narratives: critical perspectives on Carlos Fuentes, Juan Goytisolo, Mario Vargas LLosa. La Trobe University, 1987. Impreso.

Sartre, Jean-Paul. ¿Qué es la literatura? Buenos Aires: Losada. Impreso.

Schwartz, Kessel. "Juan Goytisolo, Juan sin tierra, and the Anal Aesthetic" Hispania vol. 62.1(1979): 9-19. Impreso.

Sedgwick Kosofsky, Eve. Epistemology of the closet. Los Angeles: U of California $\mathrm{P}, 1990$. Impreso.

Sobejano, Gonzalo. "Don Julián, iconoclasta de la literatura patria." Camp de l'Arpa (1977): 43-44. Impreso.

Sotomayor, Carmen. Una Lectura Orientalista De Juan Goytisolo. Madrid: Fundamentos, 1990. Impreso.

Starobinsky, Jean. "The Style of Autobiography". James Olney Ed. Autobiography. Princeton: Princeton UP. 1980. Impreso.

Unzueta, Fernando. "Escenas de lectura: naciones imaginadas y el romance de la historia en Hispanoamérica" Araucaria: Revista iberoamericana de filosofía, política y humanidades num.13, 2005, pp. 124-165. Impreso.

Vargas LLosa, Mario. "Reivindicación del conde don Julián o el crimen pasional". Contra viento y marea. Barcelona: Seix Barral, 1983. Impreso

---. “Albert Camus y la moral de los límites”. Contra viento y marea. Barcelona: Seix Barral, 1983.231-52. Impreso

-- -“Toma de posición”. Contra viento y marea. Barcelona: Seix Barral, 1983.72-74 Impreso. 
----- . La ciudad y los perros. Madrid: Santillana Ediciones, 2012. Impreso.

---- Desafíos a la libertad. Madrid: Aguilar, 1994. Impreso.

----- El pez en el agua. Madrid: Santillana, 2003. Impreso.

----- La casa verde. Barcelona: Debolsillo, 2015. Impreso.

---- Conversaciones en la catedral. Madrid: Santillana, 2010. Impreso.

----- La tía Julia y el escribidor. Barcelona: Seix Barral, 1982. Impreso.

----- El sueño del celta. Madrid: Alfaguara, 2010. Impreso.

Venkatesh, Vinodh: "Gender, Patriarchy and the Pen(is) in Three Rewritings of Latin American History" Chasqui: Revista de Literatura Latinoamericana .40.2 (2011) 95-107. Impreso.

.Vilaseca, D. "'Waiting for the Earthquake': Homosexuality, Disaster Movies and the 'message from the Other' in Juan Goytisolo's Autobiography." Paragraph Oxford. 22.1 (1999): 55-75. Impreso.

Weldt-Basson, Helen C. "El sueño del celta: Postcolonial Vargas Llosa". Redefining Latin American Historical Fiction. The impact of feminism and postcolonialism. Ed. Weldt-Besson, Helen. NewYork:Palgrave Macmillan, 2013.231-247. Impreso.

Williams, Raymon Leslie. Mario Vargas Llosa. New York: Ungar, 1986. Impreso.

Yuval-Davis, Nira. Gender and Nation. Los Angeles: Sage, 1997. Impreso.

Zamora, Andrés. "La utopía excremental de Juan Goytisolo, escritor latinoamericano. Maneras de defecar (se) en la cultura occidental" Heterotropla: Narrativas de identidad y alteridad latinoamericana, ed. C. Jâuregui y JP Dabove. Pittsburgh: Instituto Internacional de Literatura Iberoamericana. 2003, pp. 351-71. Impreso. 


\section{VITA}

\section{JOSÉ MANUEL MORCILLO GÓMEZ}

Born, Granada. Spain

BA, Education

University of Granada. Spain

1994-2010

CEO Aula 3, Professional

Training Company. Spain

1997

MA, Speech Disorders

University of Granada. Spain

2014-2017

Teaching Assistant

Florida International University

Miami. Florida

2014-2016

$\mathrm{PhD}$ Candidate in Spanish

Florida International University

2016.

MA in Spanish

Florida International University

2017- Present

Visiting Instructor and Coordinator in

Qingdao. China

Dual Degree in Spanish FIU-QU.

Florida International University

2018.

Florence Yudith Teaching Award

Florida International University. Miami

2019

$\mathrm{PhD}$ in Spanish

Florida International University. Miami

PUBLICATIONS:

Morcillo-Gómez, José. "Rompiendo moldes: Cervantes, Don Quijote y sus mujeres". Mata Induráin, Carlos ed. Recreaciones quijotescas y cervantinas en las artes. Pamplona: Eunsa. pp 249-258. 2016.

Baralt, Melissa and José Morcillo-Gómez. "Task-Based Language Teaching online: A Guide for Teachers" Language Learning and Technology. Vol 21.3. pp 28-43. October 2017. http://www.lltjournal.org/item/3008 